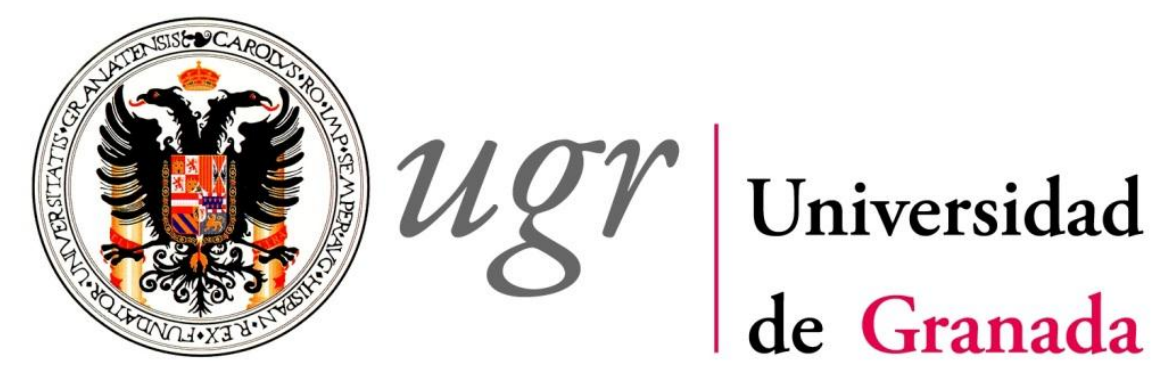

Máster en Problemas Sociales: Dirección y Gestión de Programas Sociales

Facultad de Ciencias Políticas y Sociología

Universidad de Granada

$2013-2014$

\title{
XENOFOBIA Y RACISMO EN EUROPA: UN ANÁLISIS DE LAS ACTITUDES HACIA LA INMIGRACIÓN
}

Trabajo Fin de Máster (TFM)

Alumna: Ana Belén Fernández García

Tutor: Óscar García Luengo 


\section{INDICE:}

I. INTRODUCCIÓN:

II. MARCO TEÓRICO:

1. LA CONSTRUCCIÓN DE LA INMIGRACIÓN COMO PROBLEMA SOCIAL: 6

a. LOS PROBLEMAS SOCIALES. PRINCIPALES ENFOQUES TEÓRICOS 6

b. LA CONSTRUCCIÓN SOCIAL DE LA INMIGRACIÓN
CISMO Y XENOFOBIA ENN EUROPA OCCIDENTAL:

$\begin{array}{ll}\text { 2. RACISMO Y XENOFOBIA ENN EUROPA OCCIDENTAL: } & 14 \\ \text { a. RACISMO Y XENOFOBIA } & 14\end{array}$

b. RACISMO Y XENOFOBIA EN LA EUROPA OCCIDENTAL ACTUAL 17

3. LA MEDICIÓN DEL RACISMO Y LA XENOFOBIA:

a. LA MEDICIÓN DE LAS ACTITUDES HACIA LA INMIGRACIÓN

b. APORTACIONES EN EL ESTUDIO DE LAS ACTITUDES HACIA LA INMIGRACIÓN

III. OBJETIVOS DE LA INVESTIGACIÓN: $\quad 27$

1. OBJETIVO GENERAL 27

2. OBJETIVOS ESPECÍFICOS

3. HIPÓTESIS DE TRABAJO

IV. METODOLOGÍA: $\quad 28$

1. TÉCNICAS DE PRODUCCIÓN DE DATOS 28

2. POBLACIÓN Y MUESTRA 29

3. TÉCNICA DE ANÁLISIS DE DATOS 30

4. VARIABLES DE INVESTIGACIÓN Y RECODIFICACIÓN 32

V. ANÁLISIS DE RESULTADOS:

1. ACTITUDES Y VALORACIÓN DEL IMPACTO DE LA INMIGRACIÓN EN EL PAÍS RECEPTOR

2. PERFIL DE LA ACTITUD RESTRICTIVA HACIA LA INMIGRACIÓN EN EUROPA 46

3. ANÁLISIS POR PAÍSES DE EUROPA OCCIDENTAL 65

VI. CONCLUSIONES:

1. CONTRASTE DE HIPÓTESIS 83

2. PRINCIPALES CONCLUSIONES 89

3. FUTURAS LÍNEAS DE INVESTIGACIÓN

4. APLICABILIDAD DE LOS RESULTADOS 93

VII. BIBLIOGRAFÍA: $\quad 95$

$\begin{array}{ll}\text { VIII. ANEXOS: } & 99\end{array}$ 


\section{INTRODUCCIÓN}

El interés por el estudio del racismo y la xenofobia en Europa occidental se reabre a mediados de los años ochenta, tras el avance electoral de algunas formaciones de extrema derecha, tanto a nivel nacional como europeo. En 1984, el Parlamento Europeo pasó de tener un único partido de extrema derecha representado, el MSI (Movimiento Social Italiano), a contar con tres: el MSI, el Frente Nacional francés y el EPEN griego (D’Appollonia, 2007). En la actualidad, el avance de la extrema derecha, y su contundente discurso anti-inmigración, es innegable y encabeza muchos de los sondeos electorales a nivel nacional. A nivel europeo, las últimas elecciones al Parlamento de 2014 posicionaron como primera fuerza electoral al Frente Nacional francés $(24,8 \%)$, al Partido por la Independencia del Reino Unido (26,7\%), al Partido del Pueblo Danés (26,6\%), y a otros como terceras fuerzas políticas: el FPÖ austríaco (19,7\%), los Verdaderos Finlandeses $(12,9 \%)$ y el Partido por la Libertad holandés $(13,3 \%)^{1}$.

A principios de los noventa, el avance electoral de la extrema derecha, la reaparición del antisemitismo por Europa occidental, así como la violencia racista y dirigida hacia la población inmigrante y los países del antiguo bloque comunista, activa en las Comunidades Europeas el deseo por investigar y frenar el avance racista. En 1985, el Parlamento Europeo decide la creación de una comisión de investigación sobre el ascenso del fascismo y del racismo en Europa. Se publica como resultado el Informe Evrigenis (1985), seguido de numerosas iniciativas europeas, entre ellas: una declaración conjunta de las tres instituciones europeas (Parlamento, Consejo y Comisión) contra el racismo y la xenofobia (1986); el Informe Ford sobre racismo en Europa (1990); una resolución sobre xenofobia y los peligros de la violencia de extrema derecha (1993); y una acción común adoptada por el Consejo Europeo en 1996 (D’Appollonia, 2007).

En 1997, el Eurobarómetro no 47 indicaba una preocupante generalización del racismo en Europa: cerca de un $33 \%$ de los encuestados se declaraban abiertamente "bastante racista" o "muy racista". Un Eurobarómetro más actual, sobre

\footnotetext{
${ }^{1}$ www.recursoselectorales.org
} 
Discriminación en Europa ( $n^{\circ}$ 393, 2012), señalaba que la discriminación por motivos de etnia aparece como la más generalizada en Europa (el 56\% de los encuestados declaraba que este tipo de discriminación está generalizada).

Entre las causas del nuevo avance del racismo, la xenofobia y el extremismo político de derecha, el socialdemócrata alemán, Willi Rothley, apunta "a la tendencia hacia el individualismo inherente al proceso de modernización de la sociedad. La creciente desvinculación de la familia, la iglesia y los sindicatos ha originado una creciente incertidumbre y una falta de dirección. Existe una creciente permeabilidad hacia las plataformas políticas que ofrecen seguridad acentuando los aspectos nacionales 0 que ofrecen cabezas de turco (extranjeros)" (Ford, 1991:13)².

En la actualidad, el discurso xenófobo europeo se dirige sobre la población inmigrante, con fuertes connotaciones islamófobas y una importante repercusión mediática.

La intensidad de los flujos migratorios ha creado tensiones en Europa, acentuadas en los últimos años por la crisis económica. La cuestión migratoria está siendo, además, muy politizada en el sentido de que es "objeto de mucha atención y provoca altos niveles de conflicto" (Morales y Ros, 2012). Esta banalización de la cuestión migratoria, que sirve a fines electorales para algunos, y para asentar las posiciones extremistas para otros, tienen el potencial de romper la cohesión social y legitimar la exclusión social, así como extender las acciones discriminatorias y violentas hacia los colectivos de inmigrantes. El estudio del racismo y la xenofobia, deviene entonces en algo fundamental para la sociología y la ciencia política.

La presente investigación analiza la valoración y actitudes hacia la inmigración en Europa, con el objetivo de describir su evolución en el tiempo, las diferencias entre países, así como la variación de las actitudes en función del origen étnico/racial de la población inmigrante. Se analizan también las variables, tanto individuales como contextuales, que inciden en el rechazo de la inmigración. Todo ello se realiza a

\footnotetext{
${ }^{2}$ Citado en el Prólogo del Informe Ford sobre el racismo en Europa, 1991
} 
partir de los datos ofrecidos por la Encuesta Social Europea, desde 2002 hasta 2012, tomando la última encuesta realizada como referencia. Para las variables contextuales, se recogen datos del Banco Mundial, Eurostat, y la web de www.recursoselectorales.org

La investigación consta de cinco partes principales. La primera parte está dedicada a la revisión teórica sobre el tema. Se realiza un breve repaso a los principales enfoques teóricos en el estudio de los problemas sociales, tomando como referencia teórica el enfoque de la construcción social de la inmigración. Posteriormente, se realiza una aclaración conceptual y teórica sobre el racismo y la xenofobia, y se contextualiza el tema en Europa. Por último, se analizan los principales estudios sobre actitudes hacia la inmigración, en los que se destacan tanto sus aportaciones como los debates metodológicos que la medición de las actitudes presentan.

En la segunda y tercera parte, se presentan los objetivos e hipótesis de la investigación, y el diseño metodológico de la misma. La investigación es descriptiva y de carácter cuantitativa.

En la cuarta parte se presenta el análisis de resultados de la investigación. En ella se destacan los principales resultados del análisis univariante, bivariante y multivariante realizados. Se presentan en primer lugar, la evolución en el tiempo de la valoración y actitudes hacia la inmigración obtenidas por la Encuesta Social Europea; en segundo lugar, se presentan los resultados del análisis de las variables que a nivel individual inciden en la actitud que se tiene hacia la inmigración en función del origen étnico/racial y procedencia; en tercer y último lugar, se presenta el análisis por países de Europa occidental, en el que se describen las diferentes valoraciones y actitudes hacia la inmigración que presenta cada país, así como los resultados del análisis del contexto socioeconómico, político y migratorio que inciden en la valoración del impacto de la inmigración.

Por último, la quinta parte del estudio recoge las conclusiones de la investigación. En ellas se realiza el contraste de hipótesis, se interpretan los principales resultados del análisis a la luz del marco teórico utilizado, así como las futuras líneas de investigación y aplicabilidad de los resultados de la investigación. 


\section{MARCO TEÓRICO}

\section{LA CONSTRUCCIÓN DE LA INMIGRACIÓN COMO PROBLEMA SOCIAL:}

\section{A) LOS PROBLEMAS SOCIALES. PRINCIPALES ENFOQUES TEÓRICOS:}

El estudio de los problemas sociales es uno de los campos más importantes de las ciencias sociales, en general, y de la sociología en particular. "Desde la sociología, el objetivo principal es descubrir las causas de los problemas, investigar cuáles son sus contextos determinantes y cómo están relacionados los problemas con otros fenómenos sociales" (López-Aranguren, 2005:26).

La rama de la sociología que se ocupa del estudio de los problemas sociales se remonta a la sociología americana de finales del siglo XIX y principios del XX, origen que algunos denominaron la "orientación de los problemas sociales". Por entonces, los problemas sociales eran concebidos como defectos o imperfecciones de una sociedad entendida como un orden sólido, cuyo remedio consistía en una intervención basada en el conocimiento.

López-Aranguren (2005) distingue seis enfoques en el estudio de los problemas sociales: el enfoque de la patología social, el enfoque de la desorganización social, el enfoque del etiquetaje, el enfoque crítico, el enfoque de la construcción social de los problemas sociales y el enfoque del construccionismo crítico, ésta última considerada en su mayor parte como una síntesis de la teoría del conflicto y el interaccionismo simbólico.

\section{a) Enfoque de la patología social}

El enfoque de la patología social surge a finales del siglo XIX y se difunde a principios del XX. Tiene como principales exponentes a Spencer y Durkheim (citado por López Aranguren, 2005, p. 32), y concibe a la sociedad como un organismo vivo que puede experimentar desarrollos anómalos, irregulares o extraños. Estos 
desarrollos o enfermedades desvían a la sociedad de los valores y normas compartidos por la comunidad, y se hacen responsable de ello a los individuos considerados desviados, por lo que la intervención ha de estar dirigida hacia estos mismos. Los problemas sociales guardarían su origen entonces en la falta de voluntad, en los problemas de auto-control, en debilidades psicosociales de los individuos cuyos comportamientos se salen de lo considerado normal y saludable. Esta visión de los problemas sociales no se ha extinguido por completo, y se pueden identificar vestigios de ella cuando se responsabiliza a la población inmigrante (en el caso que nos ocupa) de problemas sociales como la delincuencia, la prostitución, la pobreza, etc.

\section{b) Enfoque de la desorganización social}

El enfoque de la desorganización social nace como reacción al enfoque de la patología social, al considerar que el análisis de los problemas sociales ha de centrarse en el análisis de cómo funciona la sociedad, de qué ocurre en ella, más que en los rasgos biológicos o psicológicos de los individuos. Se puede distinguir dos versiones en el enfoque de la desorganización social, en función de si el origen de los problemas sociales se establece en los cambios sociales o en las estructuras sociales:

i. Los cambios sociales que, como la urbanización o la industrialización, suponen adaptaciones muy difíciles a las nuevas normas sociales creando confusión o desconcierto para determinados grupos sociales, y produciendo como consecuencia de ello comportamientos divergentes a las nuevas normas y valores vigentes. En este ámbito, la obra de William I. Thomas y Florian Znaniecki, El campesino polaco en Europa y América (1918-1920) es todo un referente para explicar las tensiones sociales que producen la difícil adaptación a un nuevo sistema de valores y normas, como ocurrió entre los inmigrantes polacos en la sociedad americana. En la misma línea, se encuentran las investigaciones realizadas en el seno de la Escuela de Chicago, con exponentes como Robert Park (citado por López Aranguren, 2005, p. 34) 
ii. Dos elementos de la estructura social, como son las metas u objetivos que definen la cultura y que son entendidas como socialmente legítimas, y los medios socialmente aprobados para alcanzar aquéllas, producen desajustes entre determinados grupos de la población cuando no se parte de una estructura de oportunidades igualitaria. Estos desajustes pueden aparecer en forma de comportamientos desviados y problemas sociales. Robert K. Merton (citado por López Aranguren, 2005, p. 34) es el máximo exponente de esta corriente, y propone diversas formas de adaptaciones individuales a tales desajustes estructurales: a) la conformidad, b) la innovación, c) el ritualismo, d) el retraimiento y, e) la rebelión.

\section{c) Enfoque del etiquetaje (labelling)}

El enfoque del etiquetaje, que se desarrolla en la década de 1950, centra su análisis no en los comportamientos desviados o hacia las personas que lo cometen, sino en la estructura de poder que califica una conducta como apropiada o inapropiada, legítima o ilegítima, normal o desviada. Según este enfoque, la desviación no es una cualidad del acto en sí, sino que una persona incurre en tal comportamiento cuando es etiquetado por otros como desviado social. Este enfoque fue desarrollado por autores como Becker y Goffman (citado por López Aranguren, 2005, p. 36).

\section{d) Enfoque crítico}

El enfoque crítico realiza una distinción entre macroproblemas, cuyas raíces se encuentran en la estructura social: concentración del poder económico, desigualdades en el poder y oportunidades educativas, pobreza, racismo, sexismo, etc.; y microproblemas, que aluden a comportamientos individuales o grupales: delincuencia, crimen, maltrato, alcoholismo, drogadicción, etc. El enfoque crítico considera que las personas que ocupan los puestos de poder se encargan de determinar qué problemas van a convertirse en cuestiones públicas o no, y para mantener el statu quo prefieren que sean los microproblemas los que sean merecedores de la atención pública, haciendo invisibles los macroproblemas. Para este enfoque, los problemas sociales son consecuencia de las contradicciones y 
tensiones que genera la estructura social capitalista, y su eliminación o atenuación pasa por una reestructuración de la sociedad, por la desaparición o cambio de las instituciones responsables de la estructura de poder existente. Este enfoque se extiende en los años sesenta y setenta del siglo XX, y tiene como exponente clásico a Karl Marx, siendo sus autores más recientes C. Wright Mills, Harry Braverman, y los miembros más conocidos de la Escuela de Fráncfort: Horkheimer, Adorno y Marcase (citado por López Aranguren, 2005, pp. 37-39)

\section{e) Enfoque del construccionismo crítico}

El construccionismo crítico, considerada en su mayor parte como una síntesis de la teoría del conflicto y el interaccionismo simbólico, hace hincapié en el papel que desempeñan los grupos de interés dominantes en el proceso de construcción social de los problemas sociales (enfoque que se explica a continuación). Centra su esfuerzo en analizar cómo la construcción social de los problemas está provocada por los intereses de los grupos dominantes, donde los medios de comunicación de masas juegan un papel fundamental. Este enfoque mantiene la tesis de que la concepción que mantenemos de los problemas sociales está distorsionada por las relaciones de poder implicadas en la construcción social de aquéllos. Este enfoque debe mucho a la contribución de la obra de A. Gramsci (citado por López Aranguren, 2005, p. 44), en la que desarrolló la idea de hegemonía de la clase capitalista para hacer referencia a su influencia sobre las instituciones relacionadas con la producción del conocimiento y la cultura.

\section{f) Enfoque de la construcción social de los problemas sociales}

El enfoque de la construcción social nace de la obra de P. Berger y T. Luckman, La construcción social de la realidad (1966), y se desarrolla durante los años setenta. Este enfoque se centra en los procesos a través de los cuales se construyen e interpretan los fenómenos sociales.

En el terreno que aquí nos ocupa, el de los problemas sociales, el enfoque de la construcción social lo podríamos resumir como sigue: 
a. Para comprender el mundo, las personas crean y otorgan significados a los objetos que lo componen, de forma que habría dos mundos: el físico y el de los significados. De este modo, para considerar un fenómeno objetivo como problema social hay que asignarle un significado particular (malo, indeseable, preocupante, etc.), lo que implica un razonamiento moral (¿Por qué es malo o indeseable?)

b. Estos significados no se quedan en el ámbito de la interpretación, de las ideas, sino que afecta a la misma realidad. Las personas reaccionan ante los objetos en función de los significados que le asignan a aquéllos: las categorizaciones influyen en el comportamiento.

c. Categorizar supone otorgar etiquetas a tipos de gente y de cosas, y no surgen necesariamente de los objetos, sino que dependen de la definición humana (lo que en una sociedad determinada es considerado un problema en otra no tiene por qué serlo).

d. Para comprender las categorías que nos encontramos en la sociedad se desarrollan imágenes de lo que es típico en cada caso, esto es, comprendemos el mundo que nos rodea a través de tipificaciones.

Por último, este enfoque considera que el categorizar un fenómeno social como problema social depende de dos condiciones fundamentales: i) que alguien realice la labor de convencer a otros de que se asigne a un determinado fenómeno social el significado de "pernicioso", "peligroso", "perverso"...; ii) y convencer a continuación, a aquellos que ostentan el poder o influencia de que ese problema social es importante y que hay que actuar (dedicar recursos) sobre él.

\section{B) LA CONSTRUCCIÓN SOCIAL DE LA INMIGRACIÓN:}

Decir que la inmigración es un fenómeno socialmente construido es afirmar que se crean en torno a ella representaciones, ideas que afectan no sólo a la forma de entenderla y concebirla, sino que la imagen que se tienen sobre los inmigrantes afecta también a las relaciones que se mantienen entre unos y otros, así como a su 
integración. Realidad e interpretación se mezclan y afectan al fenómeno mismo, interpretación que cambia constantemente.

Esta construcción afecta sin ir más lejos, al calificativo de persona inmigrante. Podríamos definirlo como aquella persona que entra a residir temporal o permanentemente en un país distinto al de origen -se haría referencia aquí a la inmigración internacional- (Giménez y Malgesini, 2000), indistintamente de las razones que le han llevado a hacerlo, los recursos con los que ha contado, la forma de entrar en el país, y otras cuestiones. Sin embargo, en el imaginario colectivo de la población autóctona se suele calificar como inmigrantes a personas que no lo son, al tiempo que no se consideran como tales a personas que sí han participado del proceso migratorio. Como señala Balibar (1991) "Inmigrado suele ser una categoría de amalgama que combina criterios étnicos y criterios de clase, en la que están mezclados los extranjeros, pero no todos los extranjeros ni sólo los extranjeros" ( $p$. 340).

Un primer ejemplo lo encontraríamos en los denominados "inmigrantes de segunda generación", con los que se hace referencia a los hijos de inmigrantes aunque no hayan tenido experiencia migratoria alguna. Su consideración como personas inmigrantes no es sólo una cuestión de calificativos, sino que tienen el potencial de afectar a sus relaciones sociales y a su desarrollo personal dentro de la sociedad.

Otro ejemplo sería el de aquellas personas inmigrantes que cuentan con más recursos y estatus social, los inmigrantes "ricos" (jubilados de países más desarrollados de la Unión Europea que pasan su vejez en los países del sur; los grandes empresarios o ejecutivos de empresas multinacionales que se establecen en otro país; trabajadores altamente cualificados de países procedentes de países ricos; etc.) que pasan desapercibidos y no son considerados como inmigrantes en el imaginario colectivo. A este tipo de inmigrantes es más frecuente otorgarle el calificativo de "extranjero", en el sentido de que no poseen la nacionalidad o ciudadanía del país donde habitan (Giménez y Malgesini, 2000), con una connotación más positiva que el calificativo de inmigrante. Las relaciones que se mantienen con este tipo de inmigrantes son muy diferentes a las mantenidas con el inmigrante que la mayoría de la población autóctona tiene en mente: magrebís o andinos jóvenes que vienen en busca de trabajo. 
Esto último introduce otro elemento diferenciador en la percepción que se tiene sobre la población inmigrante: la construcción social de las diferencias nacionales de los inmigrantes, esto es, las ideas que nos hacemos de ellos en función de su nacionalidad. Esta es la razón de por qué los marroquís son discriminados en el sector de la construcción en el caso español frente a los europeos del este (a los que se les reconoce mayor nivel formativo), a pesar de que aquéllos tengan más experiencia en este sector (García Borrego, 2005).

Por último, es harto frecuente encontrarse con prejuicios por el origen cultural de los inmigrantes y atribuirle comportamientos y actitudes en torno a él. Por ejemplo, a pesar de que las personas de origen marroquí cuentan con una experiencia migratoria más longeva en España que la de otras nacionalidades, se considera por muchos que su integración es más difícil en nuestra sociedad dado su origen musulmán, mientras que a otros, como los de origen latinoamericanos, se les presupone mayor facilidad de integración.

Si afirmamos que la inmigración está socialmente construida, hay que preguntarse quiénes son los actores responsables de su construcción. En este sentido, García Borrego (2005) apunta a las instituciones políticas, a los medios de información de masas $^{3}$, a determinadas organizaciones de la sociedad civil y a la Universidad como principales actores de la construcción social de la inmigración. Todos ellos juegan un papel diferente en la sociedad, en función de sus intereses, así como de sus recursos.

En primer lugar, dentro de las instituciones políticas cabe hablar de dos esferas claramente diferenciadas: por un lado, el conjunto de las Administraciones Públicas, y por otro, los partidos políticos, actores responsables de los puestos de dirección de aquéllas. No se pueden entender, entonces, como un actor monolítico, ni siquiera como un conjunto de actores que actúen siempre de forma coherente y coordinada. Para su estudio, hay que atender a su naturaleza multinivel, tanto territorial como

\footnotetext{
${ }^{3}$ García Borrego prefiere hacer referencia a los medios, como medios de información de masas en vez de medios de comunicación de masas, porque siguiendo a Jesús lbáñez, la información fluye sólo en una dirección, no se produce entonces una interacción comunicativa, además de que los medios "in-forman" a las masas, formando a las masas moldeando sus actitudes en un sentido determinado
} 
funcional. Se producen en su seno contradicciones como las políticas de integración que se pueden llevar a cabo a nivel local facilitando su acceso a los diferentes servicios y prestaciones sociales, mientras que a nivel estatal se obstaculizan aquéllas levantando muros entre "legales" e "ilegales".

En cuanto a los medios de información de masas, es indiscutible el papel fundamental que juegan en la formación de las representaciones sociales, pues gozan de un poder inigualable por otros agentes para hacer difundir un determinado mensaje, así como de la legitimidad para hacer valer su derecho a la libertad de expresión. Numerosos académicos han estudiado el papel de los "líderes de opinión" en la construcción social de la inmigración. Especialmente interesante resulta el trabajo del lingüista holandés Teun A. Van Djik (1987, 1993 y 2005), dedicado al estudio de la (re)producción del racismo de las elites en las clases populares a través de los medios de comunicación.

Otros actores responsables de la construcción social de la inmigración son los sindicatos, organizaciones empresariales, ONGs y "otros agentes menores", como algunos movimientos sociales. La baza principal de estas organizaciones es "la fuerza simbólica que les otorga su condición de representantes de eso que suele llamarse la sociedad civil" (García Borrego, 2005:24). Gracias a esa legitimidad, o "capital simbólico", pueden hacer llegar sus mensajes y opiniones en los medios de información de masas, e incluso a la agenda política. Cuentan para ello con una serie de recursos comunicativos-políticos y organizacionales, que van desde la organización de actos públicos, las relaciones con la prensa, el trabajo con las Administraciones Públicas, las conversaciones con los partidos políticos, etc., y la utilización de "medidas de presión" como las campañas, manifestaciones o actos de protestas, etc., para atraer la atención de la opinión pública y hacerse oír ante los poderes públicos.

Por último, se apunta a la Universidad como destacado agente en la construcción social de la inmigración. Esta institución jugaría un papel destacado en la medida en que se le supone la capacidad de producir un saber legítimo. Los medios de información acuden a destacados expertos sobre inmigración (normalmente, profesores e investigadores universitarios) para profundizar en los temas tratados y enriquecer la información y los debates; los agentes de la sociedad civil solicitan su 
colaboración por su especialización en asuntos migratorios para la elaboración de informes y publicaciones, organización de foros y actos; los movimientos sociales buscan su apoyo para reforzar sus argumentos al aportarles solidez; etc.

\section{RACISMO Y XENOFOBIA EN EUROPA OCCIDENTAL:}

\section{A) RACISMO Y XENOFOBIA:}

Tras estudiar numerosas definiciones que desde la antropología, sociología, psicología social, y otras disciplinas se han dado, Giménez y Malgesini (2000) concluyen que el racismo puede ser entendido de forma más restringida o amplia en la medida en que se consideren o no estas cuestiones: a) su relación con el mundo de las ideas y/o con los hechos: racismo como ideología o racismo como práctica discriminatoria apoyada o no en ideas; b) los aspectos o características personales y grupales que manejan las ideas o acciones racistas: éstos se pueden limitar a la raza, o ampliarse al ámbito étnico y cultural; c) el contexto social del racismo o la función que éste cumple en la sociedad: racismo individual o grupal, racismo como sistema de dominación.

Teniendo presente estas cuestiones, se puede diferenciar entre racismo como doctrina ideológica o racismo como conjunto de prácticas discriminatorias (aunque ésta puede estar apoyada en ideas); racismo biologista o racismo diferencialista (en función de si se cree en la superioridad de unas razas sobre otras, o si se consideran como diferentes sin que éstas deban mezclarse); racismo popular o racismo de elite (en función de las bases y procedencia que tenga el discurso racista); etc.

El holandés Teun A. Van Dijk (2005), concibe el racismo como "un sistema social de desigualdad «étnica» o «racial », al igual que el sexismo o la desigualdad por razón de clase" (p. 36), enmarcándolo en el ámbito de la estructura y el conflicto social. En una línea similar, Balibar y Wallerstein (1991) se cuestionan hasta qué punto el racismo tiene el efecto de desplazar la lucha de clases, afirmando que la noción 
moderna raza no tuvo inicialmente una significación étnica/nacional, sino una significación de clase, con el objetivo de naturalizar las desigualdades sociales. En la actualidad, el término inmigración ha sustituido al de raza, y éste "funciona como un agente de desintegración de la conciencia de clase" (p. 36).

La xenofobia hace referencia, por su parte, al rechazo $u$ hostilidad hacia las personas de origen extranjero (Giménez y Malgesini, 2000, D`Appollonia, 2007), hacia lo identificado como extraño (Xenos). La xenofobia tiene como trasfondo la distinción entre el grupo social de pertenencia, y los que son considerados como un riesgo a la integridad e identidad de ese grupo, ya sea por razones reales o supuestas (D’Apollonia, 2007). Esto significa que la xenofobia no se produce de forma exclusiva hacia el extranjero, sino que también puede dirigirse contra ciudadanos del mismo país, por lo que el estatus de ciudadano puede no ser suficiente para evitar la discriminación y el ataque xenófobo (Giménez y Malgesini, 2000). Este sería el caso de aquellos inmigrantes naturalizados, así como el de los llamados "inmigrantes de segunda o tercera generación", que a pesar de haber nacido en el país y ostentar el estatus de ciudadano, son percibidos como diferentes por sus rasgos culturales o físicos.

La xenofobia guarda también una estrecha relación con los nacionalismos excluyentes de base étnica e histórica. Ciudadanos que comparten rasgos étnicosculturales con sus atacantes pueden ser rechazados por quienes siguen un nacionalismo regional excluyente, por razones tan variopintas como no controlar la lengua local.

Se puede decir que el racismo y la xenofobia son un proceso de construcción simbólica del enemigo (Enzo Traverso, 2011), que busca satisfacer una búsqueda identitaria, así como la necesidad de seguridad y protección. "Su influencia no se basa ni en virtudes cognitivas ni en argumentos racionales sino en un dispositivo compensatorio, en la búsqueda de un chivo expiatorio" (p. 49). Y el chivo expiatorio del discurso xenófobo actual es la población inmigrante, más si proceden de países pobres y no comparten los rasgos culturales, religiosos y físicos con la mayoría del 
país receptor. Tal y como señala Balibar y Wallerstein (1991), "el término "inmigración" se ha convertido en el nombre de la raza por excelencia, nombre nuevo, pero que equivale en lo funcional a la apelación antigua" (p. 342).

En cuanto a los factores que propician su exteriorización, autores como Cea D’Ancona (2005) apuntan al desconocimiento mutuo entre la población autóctona y la inmigrante, el tratamiento de los medios de comunicación de la inmigración, los discursos políticos y la metodología seguida en su medición (de la que se hará referencia en el siguiente epígrafe).

En una línea similar, Giménez y Malgesini (2000) destacan la dimensión práctica de la xenofobia, inscrita dentro de las instituciones del estado-nación, lo que reforzaría los discursos xenófobos y las prácticas discriminatorias:

- Las políticas migratorias y de ciudadanía, diseñadas de forma para consagrar la desigualdad entre los que ostentan la nacionalidad y los que no, traduciéndose en desigualdad de derechos políticos, sociales y económicos.

- Las políticas de integración de la población inmigrante, "concebidas desde una óptica paternalista y etnocéntrica" (p.404), que además tienden a culpar públicamente a los propios inmigrantes cuando éstas acaban en fracaso.

- El comportamiento de funcionarios públicos, ya sean civiles, policiales y militares.

- El uso de discursos con trasfondos racistas y xenófobos por parte de la clase política, con el objetivo de sacar réditos electorales utilizando como chivos expiatorios a los inmigrantes.

- El trabajo de los medios de comunicación, acostumbrados a hacer de lo atípico la norma, y a relacionar a la población inmigrante con el narcotráfico, las mafias, el terrorismo, etc.

Por lo que respecta a las bases del racismo y del discurso xenófobo, las investigaciones suelen mostrar que está más extendido entre las clases populares, 
con bajos niveles educativos, escasos ingresos y cualificación. No obstante, hay autores como Van Dijk (1993) que cuestionan esta mayor incidencia del racismo en las clases populares, y destacan la mayor visibilidad del racismo de "la clase obrera blanca" respecto al "racismo de las élites", mucho más sutil. El primero se manifiesta en el voto extremista, en los discursos abiertamente racistas, en los conflictos étnicos en las barriadas pobres de las grandes ciudades, etc. Mientras que el racismo de la elite es "más indirecto, implícito y sutil, es además ignorado por las investigaciones y por los mass media. En otros términos, la élite dispone de numerosos medios para transferir, excusar o disimular sus propios prejuicios étnicos" (p. 109).

Balibar y Wallerstein (1991) señalan que el racismo que se produce dentro de la clase obrera, no es más virulento y ni debe de ocupar más atención que el que se produce dentro de las élites. El "racismo popular" está sobrestimado por los indicadores que miden las actitudes racistas, y obvian el "racismo intelectual". Añaden, además, que hablar de la extensión del racismo en la clase obrera no debe dejar en un segundo plano sus causas más profundas y estructurales: éstas no residen tanto en la competencia que se produce en el mercado de trabajo entre obreros nativos e inmigrantes, sino en "la forma en que el empresariado y el Estado han organizado la jerarquización de los trabajadores, reservando los trabajos cualificados y de dirección a los nativos y los trabajos sin cualificar a la mano de obra inmigrada, o eligiendo modelos de industrialización que exijan abundante mano de obra no cualificada, para la que se podía recurrir masivamente a la inmigración" (p. 318).

\section{B) RACISMO Y XENOFOBIA EN LA EUROPA OCCIDENTAL ACTUAL:}

En la actualidad, "la cultura xenófoba se extiende, se banaliza y se diversifica en Europa. Sus contornos son más difusos, pero más amplios" (D’Appollonia, 2007:191), superando los límites del discurso anti-inmigración. Lleva consigo un universo de valores más amplios que abarcan desde una fuerte identidad nacional, al rechazo de la integración europea, el repudio de los considerados "desviados", una escasa confianza en las instituciones y el descontento con el sistema político. La 
xenofobia, igual que el voto extremista, se nutre de las ansiedades generadas por la globalización, la fragmentación social y el multiculturalismo.

El discurso xenófobo dominante en la Europa actual "ha reemplazado la lógica del racismo biológico tradicional por un racismo diferencialista (Taguieff 1985)" (Balibar y Wallerstein, 1991, p. 37.) o "un racismo sin razas" (p. 37), donde la categoría de inmigrante sustituye a la de raza. "Un racismo cuyo tema dominante no es la herencia biológica, sino la irreductibilidad de las diferencias culturales, (...) que, a primera vista, no postula la superioridad de determinados grupos o pueblos respecto a otros, sino "simplemente" la nocividad de la desaparición de las fronteras, la incompatibilidad de las formas de vida y de las tradiciones" (p. 37).

En Europa, el etnocentrismo europeo tradicional ha evolucionado "en comunitarismo en los límites de una Europa fortaleza" (D’Appollonia, 2007:188), donde se avanza en la ciudadanía europea rompiendo fronteras interiores, al tiempo que se va creando una ciudadanía potencialmente discriminatoria que distingue ciudadanos de primera (los comunitarios) y de segunda (los no comunitarios).

Otro aspecto de la retórica xenófoba actual, es su vertiente islamófoba, tendencia reforzada a raíz de los atentados terroristas del 11 de septiembre en Nueva York, y los posteriores en Londres y Madrid. La presunta invasión islamista de Europa no se presenta sólo en términos de seguridad ciudadana, sino en clave de salvaguardar la identidad nacional y europea. En este sentido, se han planteado fuertes debates en torno al uso del velo, la construcción de minaretes, y otros elementos relacionados con la cultura árabe-musulmana, por considerar que van en contra de la laicidad de los estados europeos y de la tradición judeo-cristiana europea (Simón, 2007).

No obstante, es importante destacar que estos discursos no son monopolizados por la extrema derecha europea, sino que también son utilizados por los partidos tradicionales y las instituciones para mantenerse en el poder y obtener réditos electorales. Precisamente la banalización del discurso xenófobo por parte de gobernantes, partidos tradicionales y medios de comunicación, es lo que está reforzando y legitimando las posiciones extremistas (Giménez y Malgesini, 2000, y 
D’Appollonia, 2007), además de multiplicar los riesgos de aparición de conflicto social y violencia (Morales y Ros, 2012).

Por un lado, los medios de comunicación alimentan la ansiedad sobre una supuesta avalancha de inmigrantes y reproducen el nuevo racismo tematizando la inmigración como una amenaza; representando las relaciones étnicas en términos de problemas y desviación; sobredimensionando los sucesos relacionados con la delincuencia, drogas y violencia; obviando aquellos aspectos positivos de la inmigración, como la contribución económica y cultural de la inmigración; y, sobre todo, ocultando el racismo sutil de las élites con la intención de reducir el racismo a los extremismos y a las clases populares (Van Dijk, 1987, 1993, 2005).

Por otro, los partidos tradicionales han utilizado la cuestión migratoria para frenar el éxito de las formaciones de extrema derecha y para evitar el trasvase de voto de aquellos a éstos, especialmente entre los partidos conservadores, si bien determinados partidos de izquierda han actuado de forma similar ante la pérdida de apoyo electoral entre los trabajadores afectados por el desempleo de larga duración (Simón, 2007). Estos partidos, muchos de ellos gobernantes, han tomado medidas con el objetivo de controlar la inmigración y resolver los "problemas" de integración, y han alimentado el discurso anti-inmigración con diversas declaraciones y debates muy mediatizados. A continuación se muestran algunos ejemplos:

- En Francia, se suceden a partir de 2010 debates políticos-mediáticos sobre la "identidad nacional" francesa, y nacen medidas del Gobierno de Sarkozy con el objetivo de proteger esta identidad, como el "contrato para ser francés", o el canto de la Marsellesa en los colegios, así como el cuestionamiento del velo musulmán, por considerarse contrario a la cultura laica francesa ${ }^{4}$. Asimismo, se han llevado a cabo expulsiones masivas de gitanos rumanos y búlgaros argumentando problemas de seguridad y delincuencia ${ }^{5}$.

\footnotetext{
4 Jiménez Barca, A. (2010, 9 de febrero). Un contrato para ser francés. El País. Descargado de http://elpais.com/diario/2010/02/09/internacional/1265670002 850215.html

5 Teruel, A. (2010, 18 de agosto). Francia inicia la polémica expulsión de 700 gitanos. El País. Descargado de http://elpais.com/diario/2010/08/18/sociedad/1282082402 850215.html
} 
- En España, la "política de austeridad" alcanza en 2012 a los derechos sanitarios de la población inmigrante, al anunciar el Gobierno de Mariano Rajoy la retirada de la tarjeta sanitaria a los inmigrantes en situación irregular ${ }^{6}$.

- Italia, por su parte, saca adelante el "permiso de residencia por puntos", con el objetivo de evaluar y garantizar la "voluntad" de integración de los inmigrantes ${ }^{7}$.

- En Alemania, el debate se centra en el fracaso del multiculturalismo anunciado por la canciller Ángela Merkel. En 2010 declaraba que "los esfuerzos por construir una sociedad multicultural han fracasado absolutamente" 8 . Los partidos conservadores se enredan en debates con fuertes componentes populistas sobre la integración social de los musulmanes. El primer ministro de Baviera, Horst Sechofer declaraba que no se debían aceptar nuevos "inmigrantes de otros ámbitos culturales".

- En Reino Unido, el primer ministro, David Cameron, no sólo anunciaba el fracaso del multiculturalismo en su país, sino que además lo vinculaba con el auge del integrismo musulmán. El primer ministro criticaba la política de tolerancia de los anteriores gobiernos laboristas por convertir a los jóvenes en objeto vulnerable del radicalismo islámico ${ }^{9}$.

- En Suiza, salen adelante referéndums con ciertas connotaciones xenófobas, como el de la prohibición de la construcción de minaretes, aprobado en 2009, por considerarlo una amenaza a la cultura suiza ${ }^{10}$. O el referéndum de 2010 , en el que se aprueba la deportación de inmigrantes condenados por delitos graves, tras una fuerte campaña publicitaria elaborada por el Partido del

\footnotetext{
${ }^{6}$ Sanidad retira la tarjeta sanitaria a inmigrantes e impone el pago de algunos fármacos (2012, 1 de septiembre). RTVE. Descargado en http://www.rtve.es/noticias/20120901/sanidad-pretende-ahorrar-950-millones-retiradatarjeta-sanitaria-inmigrantes-pago-algunos-farmacos/560796.shtml

${ }^{7}$ Mora, M. (2010, 5 de febrero). Italia lanza el permiso de residencia por puntos. El País. Descargado en
www.internacional.elpais.com/internacional/2010/02/05/actualidad/1265324418 850215.html

${ }^{8}$ (2010, 18 de octubre). El debate sobre la inmigración divide a los conservadores de Merkel. El País. Descargado de http://elpais.com/diario/2010/10/18/internacional/1287352803 850215.html

${ }^{9}$ (2011, 5 de febrero). David Cameron da por fracasado el multiculturalismo en Reino Unido. El País. Descargado de http://internacional.elpais.com/internacional/2011/02/05/actualidad/1296860429 850215.html

${ }^{10}$ (2009, 29 de noviembre). Los suizos deciden en referendo prohibir la construcción de minaretes, La Voz de Galicia. Descargado de http://www.lavozdegalicia.es/mundo/2009/11/29/00031259514833150717247.htm
} 
Pueblo Suizo (en uno de los carteles difundidos por este partido, unas ovejas blancas expulsan de una patada a una oveja negra del país, donde la oveja negra representa al inmigrante, y las blancas la pureza de la población nativa suiza) ${ }^{11}$.

Por último, el neo-populismo de los partidos de extrema derecha de Europa Occidental se presentan como partidos anti-racistas en la medida en que no hablan de la superioridad de unas razas sobre otras, sino que se sirven de la lógica diferencialista del nuevo racismo para evitar ser acusados de extremistas. Dicen demandar el principio de la prioridad nacional para proteger los intereses de las clases populares de sus respectivos países, traicionados por los partidos tradicionales y el gran capital. La Unión Europea es concebida por estos partidos como el Caballo de Troya de la globalización cosmopolita y el multiculturalismo, que está permitiendo la invasión tercermundista e islamista de Europa (D’Appollonia, 2007).

El apoyo a este tipo de formaciones es cada vez mayor y más sólido, y se explica en buena parte por su adaptación a las nuevas preocupaciones ciudadanas, "como la inquietud causada por la inmigración y el multiculturalismo, la inseguridad ciudadana, el paro, la pérdida de soberanía ante organismos supranacionales y la desilusión por los partidos tradicionales" (Casals, 2003:17).

En cuanto a la inmigración, ésta es construida como un grave problema social que afecta a la Europa actual, en clave de amenaza a la identidad y cohesión nacional, de riesgo a la seguridad ciudadana, de imposibilidad de asimilación de una inmigración considerada masiva y descontrolada, de desestabilización social y económica y de encarecimiento de las viviendas y de saturación de los servicios públicos (Simón, 2007, Casals, 2003). La integración (concebida como la adaptación a las costumbres del país receptor olvidando aquellas que sean incompatibles con las de la cultura mayoritaria) es entendida por estos partidos como un paso necesario y previo a la obtención de la ciudadanía y de los derechos que conllevan, perfectamente alcanzable para todos (es concebida como una cuestión de simple

\footnotetext{
${ }^{11}$ Mir, M. (2010, 28 de noviembre) Suiza aprueba la deportación automática de los delincuentes extranjeros. El Mundo. Descargado de www.elmundo.es/elmundo/2010/11/28/internacional/1290959952.html
} 
voluntad), teniendo que ser costeado además por ellos mismos. Buscan reducir la inmigración ilegal a cero, eliminando la posibilidad de realizar regularizaciones a inmigrantes "sin papeles"; reforzar los controles fronterizos; impedir las políticas de reagrupación familiar; la suspensión y renegociación de los acuerdos de libre circulación con la Unión Europea; y la aplicación sin excepción del principio de prioridad nacional. También se exige el endurecimiento de las políticas de deportación en los casos de inmigrantes ilegales y de aquellos que, aun contando con el permiso de residencia, delincan en el país receptor ${ }^{12}$.

\section{LA MEDICIÓN DEL RACISMO Y LA XENOFOBIA:}

\section{A) LA MEDICIÓN DE LAS ACTITUDES HACIA LA INMIGRACIÓN:}

El estudio de las actitudes ha conllevado desde sus orígenes controversias, tanto por lo que se refiere a su definición como a su medición (Cea D’Ancona, 2002). En lo que respecta a su definición, Alport recopiló en su obra Attitudes (1935) más de cien definiciones del término y se decantó finalmente por una concepción mentalista del mismo, definiéndola como "un estado neuropsíquico de disposición previa a una conducta concreta ante estímulos específicos" (Cea D’Ancona, 2002: 88). Desde entonces, han aparecido nuevas concepciones del término (aquellas que enfatizan el componente conductual de las actitudes; las que las define como una respuesta evaluativa en relación a un objeto; etc.) pero se podría decir que el interés del estudio de las actitudes se ha centrado en comprobar si éstas pueden considerarse causas de las conductas, de forma que su conocimiento pudiera predecir éstas, así como modificarlas y controlarlas, cambiando previamente las actitudes (Cea D’Ancona, 2002).

Por lo que respecta a su medición, autores como Cea D’Ancona $(2002,2009)$ han reflejado en sus trabajos las principales discusiones metodológicas que se producen

\footnotetext{
${ }^{12}$ En la página web del Frente Nacional (Francia), del Partido del Pueblo Suizo, el Partido por la Independencia del Reino Unido y el Partido por la Libertad (Holanda) se pueden consultar los programas políticos de estos partidos: www.frontnational.com www.svp.ch www.ukip.org www.pvv.nl
} 
en el ámbito de la medición de las actitudes hacia la inmigración, del racismo y la xenofobia. El procedimiento de inferir la actitud a partir de declaraciones verbales de los sujetos, y la encuesta como técnica de recogida de esta información, son los dos aspectos metodológicos más debatidos.

Centrándonos en la encuesta, se reconoce la limitación de ésta para captar las actitudes racistas o xenófobas. La principal debilidad de la encuesta para medir este tipo de actitudes es su vulnerabilidad al sesgo de deseabilidad social, pudiendo poner en riesgo la validez y fiabilidad de la encuesta como estrategia metodológica. La deseabilidad social es un sesgo que se produce por el estigma que en nuestras sociedades conlleva admitir actitudes, posicionamientos o comportamientos contrarios a los principios constitucionales de igualdad de trato y no discriminación por motivos de raza, etnia, sexo, edad, etc. Esto hace que los encuestados no deseen mostrar actitudes que puedan considerarse socialmente indeseables, llevando a errores de medición ya sean por la "sobredeclaración" de respuestas concordantes con lo políticamente correcto, o por numerosos casos de no respuesta total o de ítem (Cea D’Ancona, 2009). Por ello, Cea D’Ancona (2002, 2009) advierte de la conveniencia de mejorar la técnica de la encuesta y de combinarla con otras estrategias de investigación, para no caer en la sobrerrepresentación de las actitudes consideradas positivas ante la inmigración.

El sesgo de la deseabilidad social es más frecuente en personas con más edad y con mayor nivel educativo, al captar en mayor medida la intencionalidad de las preguntas y por el interés de no aparecer como personas racistas o xenófobas. También son más vulnerables a este sesgo los indicadores directos de racismo y xenofobia, que los indirectos, así como las entrevistas realizadas telefónicamente (Cea D’Ancona, 2009, Izquierdo, 1995).

También se critica la limitación de las encuestas tradicionales al no incluir indicadores de los distintos tipos de racismo que se dan en la actualidad. El racismo "biológico" es el que tradicionalmente se ha recogido en los diferentes estudios de opinión, pero existen otros tipos de racismos más sutiles que se dan frecuentemente en la sociedad y que, sin embargo, no suelen estar contemplados en la medición de las actitudes racistas (Cea D’Ancona, 2002; Izquierdo, 1995) 


\section{B) PRINCIPALES APORTACIONES EN EL ESTUDIO DE LAS ACTITUDES HACIA LA INMIGRACIÓN:}

En cuanto a los estudios realizados sobre las actitudes hacia la inmigración, Martin, Molina y Meardi (2003) distinguen numerosas variables explicativas de éstas y que pueden ser agrupadas en tres grandes dimensiones: económicas, culturalesideológicas y contextuales.

En primer lugar, predomina en la literatura sobre el tema estudios que enfatizan las variables económicas, como el desempleo, la pobreza y los salarios (Martin, et al, 2003). Los inmigrantes son considerados como competidores por unos recursos escasos, principalmente el empleo, y como causa del deterioro de las condiciones laborales, los salarios, aumento de las jornadas de trabajo, etc.

Sociólogas como Carlota Solé (2000), han estudiado el impacto que ejerce la inmigración en la sociedad receptora desde el punto de vista de las "condiciones materiales objetivas" (empleo, vivienda, servicios sociales, etc.). Estas condiciones materiales pueden producir una situación de competencia o complementariedad entre autóctonos e inmigrantes, concluyendo que tras las diferencias culturales (problemas de integración y prejuicios, entre otras) se encuentran subyacentes otras de carácter socioeconómicas, como la clase social, la ocupación y el nivel educativo. En una línea similar, Díez Nicolás (2005) apunta a que la discriminación hacia la población inmigrante, "son expresión de un clasismo muy arraigado" (p. 189), explicándose más en términos de clase social que de razas o culturas.

Solé (2000) y Cea D’Ancona y Valles (2010), apuntan a la competencia por recursos escasos, como el empleo y el bienestar, como factor explicativo de las actitudes xenófobas en España. Especialmente, los contextos de crisis económicas favorecen la politización de la inmigración y los discursos xenófobos en clave de competencia (Cea D’Ancona, 2005). Estos enfoques socioeconómicos enfatizan la sensación de amenaza o vulnerabilidad de la población autóctona respecto a la llegada de inmigrantes, así como en las implicaciones laborales y de bienestar material que supone (Martin et al, 2003). 
Por lo que respecta a la dimensión cultural-ideológica, encontramos estudios que han reclamado la importancia explicativa de las variables vinculadas con los valores culturales e ideológicos en la configuración de las actitudes hacia la inmigración (Martin et al, 2003). Estudios como el de Rodríguez Monter (2009) han demostrado la importancia de los aspectos de convivencia y cultura -idioma y costumbres- para explicar la aceptación o rechazo de la inmigración por parte de la población autóctona. El análisis que realiza sobre 20 países, le permite concluir que los criterios más importantes para que un país sea receptivo o no a la llegada de inmigrantes son aquellos que están relacionados con "la adopción de las costumbres y pautas culturales por parte de éstos, seguidos de las cuestiones laborales y el idioma" (Rodríguez Monter, 2009: 220).

Innerarity y Acha (2010), por su parte, analizan cómo las sociedades europeas están gestionando la diversidad cultural y socioeconómica ante el fenómeno de la inmigración, las tendencias en las políticas de ciudadanía (que parecen favorecer la dimensión cívico-postnacional universalista de la ciudadanía frente al particularismo étnico-nacional) y el reto que suponen los discursos extremistas de la derecha populista, que se oponen firmemente al multiculturalismo exigiendo políticas de retorno y de restricción de la inmigración, en un momento en el que parecen ganar apoyo electoral y social entre los europeos.

Por último, la tercera dimensión hace hincapié en cómo las variables contextuales tasa de desempleo, tasa de inmigración, PIB per cápita, gasto en políticas sociales, etc.- juegan un papel muy importante en la configuración de las actitudes que la población autóctona mantiene respecto a la inmigración (Mayda, 2006; Burkhardt, 2009).

Las políticas redistributivas del Estado del Bienestar contribuyen a mitigar las desigualdades entre autóctonos e inmigrantes, aumentando la cohesión social y reduciendo el conflicto (Martin et al, 2003). Sin embargo, cuando en momentos de crisis económica o recesión se reduce el gasto público la población autóctona puede sentir amenazadas las políticas del bienestar si perciben que la población inmigrante hace aumentar la presión en el gasto. Al mismo tiempo, son concebidos como competidores, especialmente en el ámbito de los servicios sociales, si los requisitos 
de acceso a éstos son determinados en función de las necesidades (por lo general, éstas son mayores entre la población inmigrante que en la autóctona) y si el presupuesto destinado a estos servicios son escasos (Bruquetas y Moreno, 2011). No olvidemos que los estados del bienestar se asentaron bajo la idea de una fuerte solidaridad nacional, favoreciendo actitudes excluyentes ("chovinismo del bienestar") en momentos de incertidumbre económica y social. 


\section{OBJETIVOS DE LA INVESTIGACIÓN}

\section{OBJETIVO GENERAL:}

Esta investigación tiene como objetivo general estudiar las actitudes hacia la inmigración en Europa, analizando su evolución en los últimos años, las variables que ayudan a identificar el perfil de quienes mantienen una actitud restrictiva hacia la inmigración, y las principales diferencias entre los países de Europa occidental.

\section{OBJETIVOS ESPECÍFICOS:}

a. Analizar la evolución de las actitudes hacia la inmigración en Europa en los últimos años, y comprobar las distintas actitudes que se tienen hacia los inmigrantes en función de su origen étnico/racial y procedencia.

b. Identificar las principales variables que influyen en la actitud que se mantienen hacia los inmigrantes procedentes de países pobres de fuera de la Unión Europea.

c. Examinar las actitudes que se tienen hacia la inmigración en los países de Europa Occidental, las diferencias que se producen entre ellos, y su posible relación con variables de carácter macroeconómicas, migratorias, sociales y políticas.

\section{HIPÓTESIS DE TRABAJO:}

a. En los últimos años, se ha extendido el rechazo hacia la inmigración por el continente europeo. El rechazo es mayor hacia los inmigrantes de diferente raza o etnia que la mayoritaria y, en especial, si son procedentes de países con un perfil socioeconómico bajo.

b. La actitud hacia la inmigración depende en buena medida de variables de carácter socioeconómicas, tales como la edad, el nivel de estudios, la situación laboral, la ocupación y los ingresos. No obstante, otras variables de tipo político-culturales, así como la valoración que se haga de la actualidad 
política, social y económica, juegan un papel muy destacado en la conformación de las actitudes hacia la inmigración.

c. Las actitudes que se mantienen hacia la inmigración varían en cada país europeo, si bien es generalizable una percepción negativa del efecto que tiene la inmigración en el país receptor.

a. No hay una correspondencia clara entre el rechazo hacia la inmigración y una mayor tasa de población inmigrante, teniendo más peso otras variables contextuales como el nivel de desempleo o la desigualdad social.

b. A pesar de que las formaciones de extrema derecha hacen del discurso anti-inmigración una de sus principales bazas electorales, no se produce una correspondencia entre el mapa del extremismo y la actitud de rechazo hacia la inmigración.

\section{METODOLOGÍA:}

\section{TÉCNICA DE PRODUCCIÓN DE DATOS:}

La investigación está apoyada en los datos secundarios extraídos de la explotación de bases de datos de las principales fuentes estadísticas a nivel europeo e internacional:

- Encuesta Social Europea (ESE): es la principal fuente de datos secundarios utilizada en esta investigación. La ESE se realiza cada dos años, y se inició en 2002. Esta encuesta mide las actitudes, creencias y patrones de comportamiento de las diferentes poblaciones de más de 30 países europeos y algunos vecinos, como Israel y Turquía.

Para el análisis detallado se ha utilizado la ESE 2012 (Ronda 6), realizada a 28 países europeos e Israel: Albania, Bélgica, Bulgaria, Chipre, República Checa, Dinamarca, Estonia, Finlandia, Francia, Alemania, Holanda, Hungría, Islandia, Irlanda, Italia, Kosovo, Lituania, Noruega, Polonia, Portugal, Rusia, Eslovaquia, Eslovenia, España, Suecia, Suiza, Ucrania y Reino Unido. 
Por su parte, para el análisis longitudinal se han utilizado todas las encuestas realizadas desde sus inicios: 2002, 2004, 2006, 2008, 2010 y 2012.

- Eurostat: esta fuente de información de la Comisión Europea ha sido utilizada para obtener los datos sobre inmigración en Europa, índice Gini y gasto en protección social

- Banco Mundial. Se han extraído de este organismo los datos macroeconómicos de los países de Europa occidental: porcentaje de desempleo, porcentaje de desempleo de larga duración, crecimiento del PIB, PIB per cápita, gasto en educación y sanidad.

- www.recursoselectorales.org Página web que recoge los resultados electorales de países de todo el mundo. Se ha utilizado para la elaboración de la base de datos del análisis contextual.

- Página web del Manifiesto Project, elaborado por la Universidad de Berlín, para consultar la ubicación ideológica de los partidos políticos analizados.

\section{POBLACIÓN Y MUESTRA:}

La Encuesta Social Europea utiliza una muestra representativa a personas mayores de 15 años (sin límite superior de edad), residentes en hogares de cada país, con independencia de su nacionalidad, ciudadanía o idioma. Todos los países deben alcanzar un mínimo de 1.500 individuos, 800 en el caso de países con poblaciones menores de dos millones de habitantes. Los individuos son seleccionados por métodos probabilísticos aleatorios muy estrictos en todas las etapas, quedando descartado el muestreo por cuotas así como la sustitución de los hogares o individuos que no hayan respondido. El total de la muestra es de 54.673 casos.

Para el análisis por países, se han utilizado las bases de datos de los 15 países de Europa Occidental que participaron en 2012 (entre paréntesis, el tamaño de las muestras de cada país): Alemania (2958), Bélgica (1869), Dinamarca (1650), España (1889), Finlandia (2197), Francia (1968), Irlanda (2628), Islandia (752), Italia (960), Noruega (1624), Países Bajos (1845), Portugal (2151), Reino Unido (2286), Suecia (1847), Suiza (1493). 


\section{TÉCNICA DE ANÁLISIS DE DATOS:}

La investigación es de tipo descriptiva, pues busca caracterizar las actitudes hacia la inmigración en Europa, identificar las relaciones que se producen entre dos o más variables, así como describir su evolución en los últimos años y las diferencias producidas entre los países europeos analizados.

Se trata además de una investigación cuantitativa: a partir del software estadístico SPSS se ha realizado un análisis descriptivo de las variables, de carácter univariante, bivariante y multivariante.

En el análisis univariante se presenta la distribución de frecuencias y la evolución de las variables dependientes del estudio obtenidas de la Encuesta Social Europea. Los principales resultados del análisis univariante se representan a partir de gráficos de barras y columnas realizadas con el software Microsoft Excel.

Para analizar la relación de las variables individuales de los encuestados en la variable dependiente, se han utilizado tablas de contingencia para estudiar las diferentes pautas de asociación entre ellas. Siguiendo a Sánchez Carrión (1999), el mejor estadístico que encontramos para ver la relación entre variables nominales es la diferencia de porcentajes. No obstante, esta parte del análisis se ha apoyado también en el estadístico de contraste Chi-cuadrado, para contar con un criterio más objetivo a la hora de rechazar o no la hipótesis nula de independencia. El criterio elegido para rechazar la hipótesis nula o hipótesis de independencia de las variables (indica que las variables no están asociadas) ha sido establecer el nivel de significación en 0,01 , de modo que cuando el nivel de significación observado sea menor a éste, se pueda rechazar la hipótesis nula. Por el contrario, cuando el nivel de significación observado o asintótico sea superior a 0,01 no se podrá afirmar que existe una asociación entre las variables. Se ha elegido el nivel de significación de 0,01 en vez de 0,05 porque el tamaño de la muestra es muy grande (casi 55.000 casos), y una de las limitaciones del estadístico Chi-cuadrado es su vulnerabilidad al tamaño de la muestra, de forma que cuando ésta es demasiado grande hay más probabilidad de que el valor del estadístico sea mayor y, por tanto, se rechace la hipótesis nula de independencia. 
Se han controlado las frecuencias esperadas menores de 5 en las tablas de contingencia que cruzan la variable dependiente con el voto a partidos en los diferentes países analizados, pues se han encontrado categorías con un recuento de casos muy pequeños. Para ello, se ha tomado como criterio para considerarlos estadísticamente válidos, el que las frecuencias esperadas menores de 5 no sobrepasen el $20 \%$ del total de frecuencias de la tabla de contingencia.

También se han realizado tablas de control cuando se ha considerado conveniente comprobar la influencia que terceras variables puedan ejercer en la relación entre la variable dependiente y las independientes. Como criterio general, se ha considerado que la relación entre dos variables son independientes de la influencia de terceras cuando la relación entre aquellas se mantenga más o menos firme pese a la introducción de la variable de control. También se han utilizado estas tablas para especificar las condiciones en las que se produce la relación entre dos variables, así como para analizar el efecto conjunto de dos variables independientes sobre la dependiente (Sánchez Carrión, 1999). En este sentido, el que el tamaño de la muestra sea tan grande permite el poder controlar la muestra por una tercera variable y analizar su comportamiento respecto a la variable dependiente, manteniendo un considerable tamaño muestral en cada grupo o categoría.

Para analizar la interacción entre estas variables, se ha procedido con un análisis multivariante a partir de los árboles de clasificación por el algoritmo CHAID. Este algoritmo crea segmentos y perfiles respecto a la variable dependiente, diferenciando entre aquellas variables independientes (predictoras) que muestra la interacción más fuerte con la dependiente. Las categorías de cada variable predictora se funden (son presentadas en el mismo grupo o nodo) si no muestran diferencias significativas en su relación con la variable dependiente. El resultado se muestra en un árbol de clasificación compuesto por diferentes nodos, que representan un comportamiento homogéneo en su interior, y diferente respecto al resto de nodos (Escobar Mercado, 2007).

Los árboles de clasificación utilizados han segmentado la muestra en función de las siguientes variables: clase social subjetiva, situación laboral y edad, en el primer árbol; nivel educativo, ingresos e ideología, en el segundo; y, por confesión religiosa, ideología y edad, el tercero. Los tres árboles cuentan con una profundidad máxima 
de tres (tres niveles de segmentación), 100 casos mínimos en el nodo padre, y 50, en los nodos hijos.

Por último, para el análisis de las variables contextuales se ha utilizado el estadístico de correlación lineal $\mathrm{R}$ de Pearson, y se ha seguido el siguiente criterio para interpretar la intensidad de la correlación entre las variables:

- Entre 0 y +/- 0,2: correlación muy baja o nula

- Entre +/- 0,2 y +/- 0,4: correlación baja

- Entre +/- 0,4 y +/-0,7: correlación sustancial

- Entre +/-0,7 y +/- 1: correlación alta o muy alta

En la tabla resumen, aparece marcado con un asterisco los coeficientes que son significativos al nivel del 0,05 y con dos asteriscos los que lo son al nivel del 0,01.

\section{VARIABLES DE INVESTIGACIÓN Y RECODIFICACIÓN:}

\section{a) Variables dependientes:}

Las variables utilizadas para el análisis univariante son las siguientes:

\section{VARIABLES DEPENDIENTES}

Actitud hacia la inmigración de personas de la misma raza/grupo étnico que la mayoritaria

Actitud hacia la inmigración de personas de diferente raza/grupo étnico que la mayoritaria Actitud hacia la inmigración de personas procedentes de países pobres de fuera de la UE

Valoración efecto de la inmigración en la economía del país

Valoración efecto de la inmigración en la cultura del país

Valoración efecto de la inmigración en el país como lugar para vivir

Para el análisis de las variables individuales de los encuestados, se ha utilizado una única variable dependiente: "Actitud hacia la inmigración de personas procedentes de países pobres de fuera de la UE”. Este tipo de inmigración es el menos deseable 
socialmente (Martín, Molina y Meardi, 2013) en la medida en que reúnen la condición de "pobres" y con casi toda seguridad sean de diferente raza/grupo étnico que la mayoritaria (inmigración procedente de países africanos, asiáticos y latinoamericanos), por lo que a la competencia por recursos de empleo y bienestar se suma el posible choque cultural con personas con costumbres, valores y aspecto físico diferentes.

Para el análisis de las variables contextuales, se han utilizado las valoraciones del efecto de la inmigración en la economía, cultura y condiciones de vida del país receptor como variables dependientes.

b) Variables independientes:

SOCIOECONÓMICAS
Sexo
Edad
Nivel estudios
Lugar residencia
Situación laboral
Ocupación
Ingresos
Clase social subjetiva
Ciudadanía del país donde habita actualmente

\section{POLITICO-CULTURALES}

\section{Ideología}

Confesión religiosa

Interés por la política

Confianza en la gente

Confianza en las instituciones: sistema judicial

Confianza en las instituciones: partidos políticos

Que los derechos de las minorías estén protegidos

Que gays y lesbianas puedan vivir libremente como quieran 
Satisfacción con el estado de la economía en su país

Satisfacción con el funcionamiento de la democracia en su país

Satisfacción con la labor del gobierno nacional en su país

Valoración condiciones de vida de la mayoría de la población de su país

Valoración de la velocidad de la integración europea

Valoración de la seguridad de su barrio

c) Variables de control:

VARIABLES DE CONTROL
Nivel de estudios
Edad
Ingresos

d) Recodificación de variables:

\section{VARIABLES DEPENDIENTES:}

\section{Actitud hacia la inmigración:}

¿Hasta qué punto se debería permitir que personas de la misma raza o grupo étnico que la mayoría de los españoles vengan a vivir aquí?

¿y personas de distinta raza o grupo étnico que la mayoría de los españoles vengan a vivir aquí?

¿y los que proceden de los países pobres de fuera de Europa?

Se debería permitir que muchos vinieran a vivir aquí (1), Permitir que vinieran unos cuantos (2), Permitir que vinieran unos pocos (3), No se debería permitir que ninguno viniera a vivir aquí (4), No sabe, no contesta (8)

- Permisiva (1-2)

- Restrictiva (3-4)

- Ns/nc (8)

Valoración del efecto de la inmigración en la economía/cultura/lugar para vivir:

¿Diría Ud. que, por lo general, para la economía, es bueno o es malo que gente de otros 
países venga a vivir aquí?

¿Cree Ud. que la vida cultural se empobrece o se enriquece con las personas de otros países que vienen a vivir aquí?

La llegada de personas de otros países, ¿contribuye a que su país sea un lugar peor o mejor para vivir?

Escala 0-10 (0: malo- 10: bueno)

- Negativo (0-4)

- $\quad$ Ni negativo, ni positivo (5)

- Positivo (6-10)

\section{SOCIOECONÓMICAS}

Edad: intervalos de 15 años, agrupando entre el 20 y 30\% de los casos en cada categoría:

- 15-29 años

- 30-44 años

- 45-59 años

- $\quad>60$ años

Estado civil: casados y parejas de hecho, y divorciados y separados se unen en una categoría

- Casado/a o pareja de hecho

- Divorciado/a o separado/a

- Viudo/a

- Soltero/a

Nivel estudios: $\mathrm{n}^{\circ}$ de años de estudios completados

- Estudios primarios o sin estudios (hasta 8 años)

- Estudios secundarios (de 9 a 14 años)

- Estudios superiores (más de 15 años)

\section{Lugar residencia:}

- En la gran ciudad

- A las afueras o suburbios de una gran ciudad

- En una ciudad de tamaño medio o pequeño

- En un pueblo o casa de campo 


\section{Situación laboral: \\ - Trabajador remunerado \\ - Estudiante \\ - Desempleado \\ - Jubilado/a o incapacitado/a para el trabajo \\ - Labores del hogar y/o cuidado familiares \\ Otros (aquí se incluyen "servicios miliares o a la comunidad")}

Ocupación: clasificación ISCO-08 de la OIT

- Ocupaciones militares

- Gerentes

- Profesionales

- Técnicos y profesionales de nivel medio

- Personal de apoyo administrativo
- Trabajadores de los servicios y de ventas

- Trabajadores expertos en agricultura, pesca y forestal

- Artesanía y otros oficios

- Operadores de instalaciones y máquinas

- Ocupaciones elementales

Ingresos: se ofrecen diez tramos (deciles) de ingresos, ordenados de menor a mayor ingresos

- Bajos: dos primeros tramos

- Medios-bajos: del tercer a quinto tramo

- Medio-altos: del sexto al octavo tramo

- Altos: dos últimos tramos

Clase social subjetiva: escala de 0-10 (0: lo más bajo de la sociedad - 10: lo más alto)

- $\quad$ Baja (0-2)

- Media-baja (3-4)

- Media (5)

- Media-alta (6-7)

- $\quad$ Alta (8-10) 


\section{POLITICO-CULTURALES}

Ideología: escala ideológica (0: izquierda - 10: derecha). Se mantiene "no sabe/no contesta" porque contiene un número importante de casos.

- Extrema izquierda (0-1)

- Centro-izquierda (2-4)

- Centro (5)

- Centro-derecha (6-8)

- Extrema derecha (9-10)

- $\quad$ No sabe/no contesta $(77,88,99)$

Confesión religiosa: "religiones orientales" y "otras no cristianas" se unen porque tienen un comportamiento similar respecto a la variable dependiente y un recuento bajo de casos

- Católica

- Protestante

- Ortodoxa

- Otras confesiones cristianas

- Judía

- Musulmana

- Religiones orientales y otras no cristianas

Interés por la política: mucho (1), bastante (2), poco (3), nada (4)

- Mucho o bastante (1-2)

- Poco o nada (3-4)

Confianza en la gente: escala 0-10 (0: nunca se es lo bastante prudente - 10: se puede confiar en la mayoría de la gente)

- Muy desconfiado (0-2)

- Desconfiado (3-4)

- Ni confiado, ni desconfiado (5)

- Confiado (6-7)

- Muy confiado (8-10)

Confianza en las instituciones: partidos políticos: escala 0-10 (0: nunca se es lo bastante prudente - 10: se puede confiar en la mayoría de la gente)

- Muy desconfiado (0-2)

- Desconfiado (3-4) 
- $\quad$ Ni confiado, ni desconfiado (5)

- Confiado (6-7)

- Muy confiado (8-10)

Confianza en las instituciones: sistema judicial: escala 0-10 (0: nunca se es lo bastante prudente - 10: se puede confiar en la mayoría de la gente)

- Muy desconfiado (0-2)

- Desconfiado (3-4)

- $\quad$ Ni confiado, ni desconfiado (5)

- Confiado (6-7)

- Muy confiado (8-10)

Que los derechos de las minorías estén protegidos: escala 0-10 (0: nada importante - 10: muy importante)

- Nada importante (0-2)

- Poco importante (3-4)

- Ni poco ni muy importante (5)

- Bastante importante (6-7)

- Extremadamente importante (8-10)

\section{VALORACIÓN ACTUALIDAD POLITICA, ECONÓMICA Y SERVICIOS PÚBLICOS}

Satisfacción con el estado de la economía en su país / con el funcionamiento de la democracia en su país / con la labor del gobierno nacional en su país: escala 0-10 (0: muy insatisfecho - 10: muy satisfecho)

- Muy insatisfecho (0-2)

- Insatisfecho (3-4)

- $\quad$ Ni satisfecho, ni insatisfecho (5)

- Satisfecho (6-7)

- Muy satisfecho (8-10)

Valoración de la integración europea: escala 0-10 (0: La integración ya ha ido demasiado lejos - 10: la integración debería ir más lejos)

- La integración ha ido demasiado lejos (0-3)

- La integración es adecuada (4-6) 
- La integración debería ir más lejos (7-10)

Se siente seguro en su barrio: muy seguro/a (1), seguro/a (2), inseguro/a (3), muy inseguro/a (4)

- Seguro o muy seguro (1-2)

- Inseguro o muy inseguro (3-4) 


\section{ANÁLISIS DE RESULTADOS}

\section{ACTITUDES Y VALORACIÓN DEL IMPACTO DE LA INMIGRACIÓN EN EL PAÍS RECEPTOR}

\section{A. Actitudes hacia la inmigración en función de su origen étnico/racial y procedencia:}

La variable dependiente de la investigación "Actitud hacia la inmigración procedente de países pobres de fuera de la Unión Europea"13 es formulada en la encuesta como una pregunta con cuatro posibles respuestas: "permitir a muchos", "permitir a unos cuantos", "permitir a unos pocos" y "no permitir a ninguno", además del "no sabe, no contesta". Esta variable se compara con otras dos muy similares, para analizar la diferente actitud que se tiene hacia la inmigración en función de su origen étnico/racial y procedencia: "actitud que se mantiene hacia la inmigración del mismo origen étnico/racial que la mayoría" y "actitud que se mantiene hacia la inmigración de personas inmigrantes de diferente raza/grupo étnico que la mayoría".

Los resultados de la Encuesta Social Europea de 2012 (Gráfico 1) muestran que la categoría que más casos reúne es la de "permitir (la entrada) a unos cuantos", tanto en el caso de inmigrantes de la misma raza/grupo étnico (42,5\%), de diferente raza/grupo étnico $(38,2 \%)$, y de personas procedentes de países pobres no comunitarios (34\%). La categoría "permitir (la entrada) a unos pocos", es la segunda con más frecuencias, si bien el orden se invierte (de mayor a menor): personas procedentes de países pobres no comunitarios $(31,9 \%)$, inmigrantes de diferente raza/grupo étnico $(31 \%)$ y, por último, inmigrantes de la misma raza/grupo étnico $(22,5 \%)$. Este mismo orden se repite en la categoría "No permitir la entrada a ninguno" ( $21 \%, 16,1 \%$ y $9,4 \%$ respectivamente), mientras que el orden es el inverso entre los que permitirían la entrada a muchos inmigrantes: de la misma raza/grupo

\footnotetext{
${ }^{13}$ Anexo 1, tablas I.I. y I.II.
} 
étnico $(25,6 \%)$, de diferente raza/grupo étnico $(14,7 \%)$ o procedentes de países pobres de fuera de la Unión Europea (13,1\%).

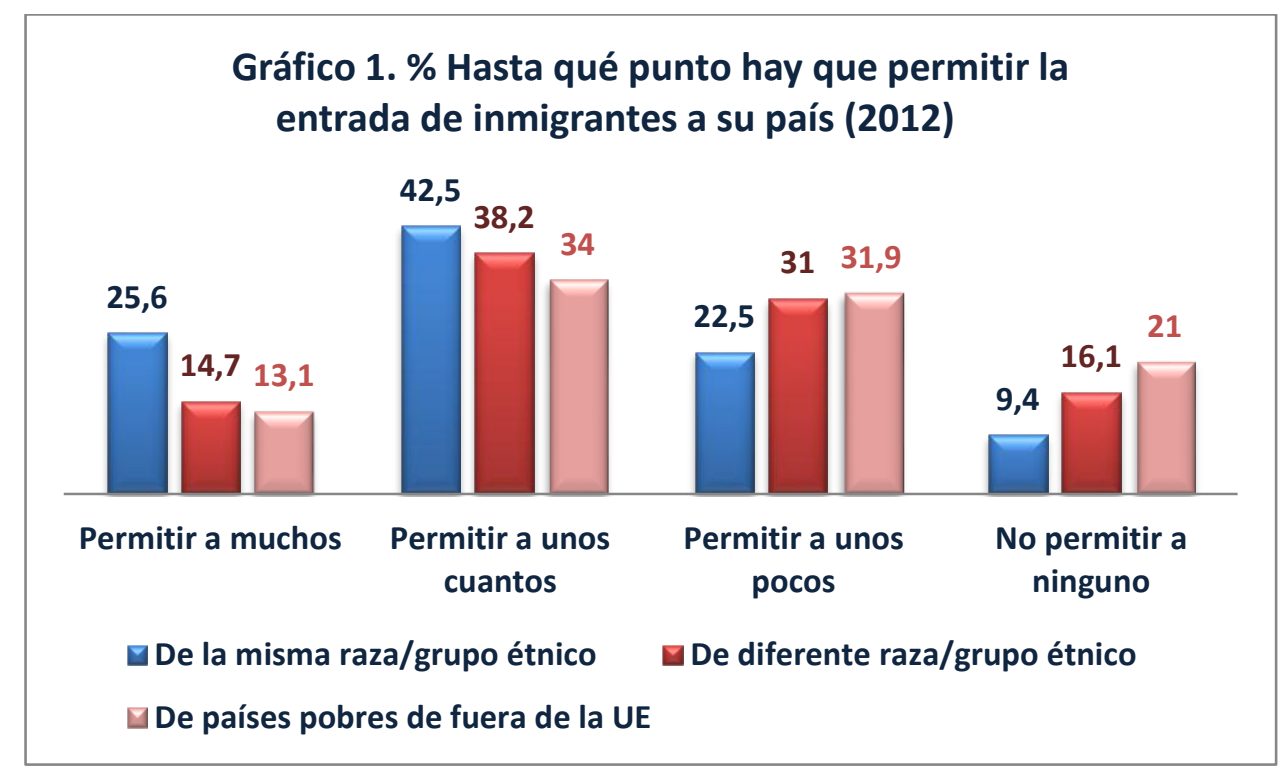

Fuente: elaboración propia a partir de la ESE 2012

Lo que están indicando estos porcentajes es que la actitud favorable a la entrada de inmigración es mayor o menor en función del origen étnico/racial de la población inmigrante y de su procedencia: el nivel de aceptación es bastante mayor para aquellos que comparten origen étnico/racial con la mayoría del país donde se realiza la encuesta, e inferior para aquellos con diferente origen étnico/racial $y$, especialmente, de los que proceden de países pobres de fuera de la Unión Europea.

Al recodificar estas variables en dos categorías (actitud permisiva y actitud restrictiva) se puede apreciar (Gráfico 2 ) cómo la actitud permisiva ante la recepción de población inmigrante es bastante mayor en el caso de que ésta comparta el mismo origen étnico/racial que la mayoría $(68,1 \%)$ e inferior entre los que son diferentes en términos étnico/raciales (52,9\%). Por su parte, el mayor porcentaje de actitud restrictiva hacia la entrada de inmigrantes se da en el caso de que procedan de países pobres de fuera de la Unión Europea (52,9\%). De hecho, es la única variable que registra una actitud mayoritariamente restrictiva, mientras que en las otras dos la actitud mayoritaria es la permisiva (si bien con una importante diferencia en función del origen étnico/racial del inmigrante). 


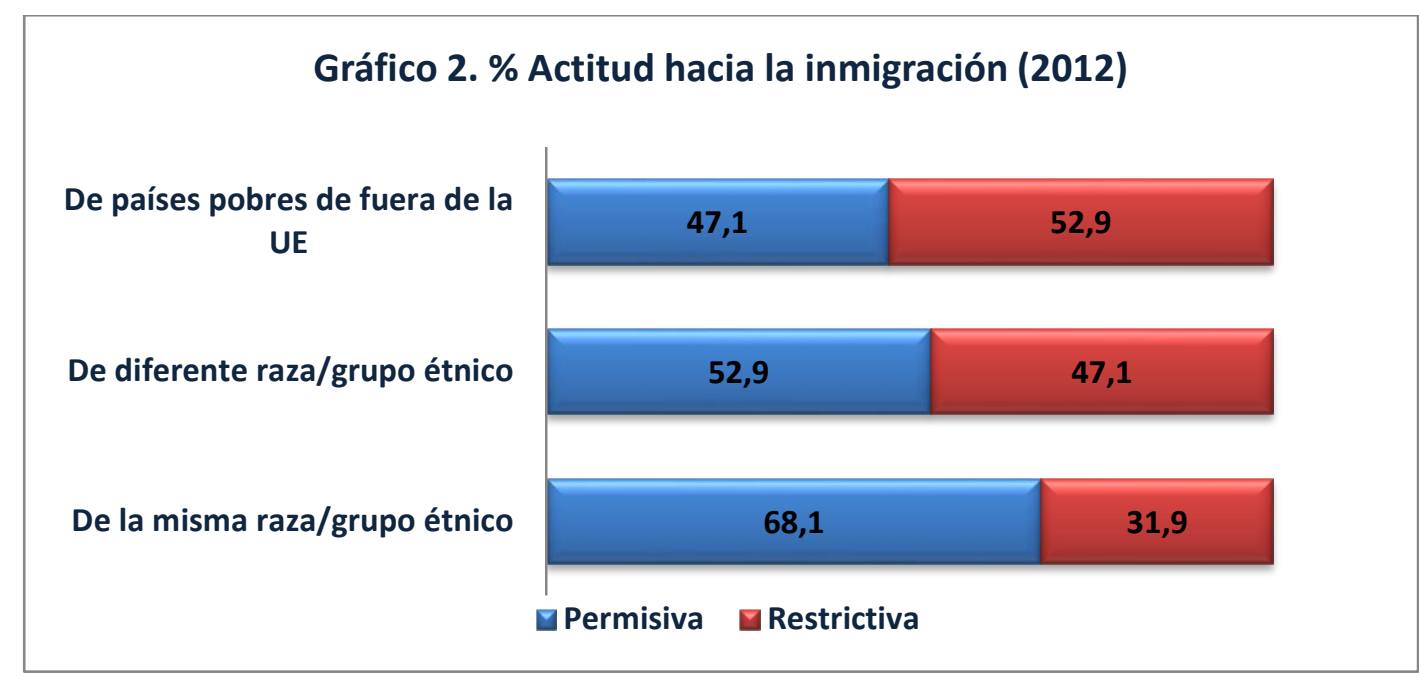

Fuente: elaboración propia a partir de la ESE 2012

Si se analiza la evolución que ha seguido la actitud hacia la inmigración en función del origen étnico/racial y procedencia de la población inmigrante (Gráfico 3), se puede apreciar cómo, a excepción de 2002, la actitud restrictiva hacia la entrada de inmigración es mayor en el caso de que ésta proceda de países pobres de fuera de la Unión Europea, siempre por encima del $52 \%$ y con una tendencia creciente hasta 2010, donde alcanza su valor máximo $(55,1 \%)$. Le sigue de cerca la actitud restrictiva hacia la población inmigrante de diferente raza/grupo étnico que la mayoría, con valores en torno al $49-50 \%$. Por último, la actitud restrictiva hacia la inmigración de personas de la misma raza/grupo étnico que la mayoría es la que menos frecuencias de rechazo registra (en torno al 32-36\%) y con una tendencia más o menos estable en los últimos años. 


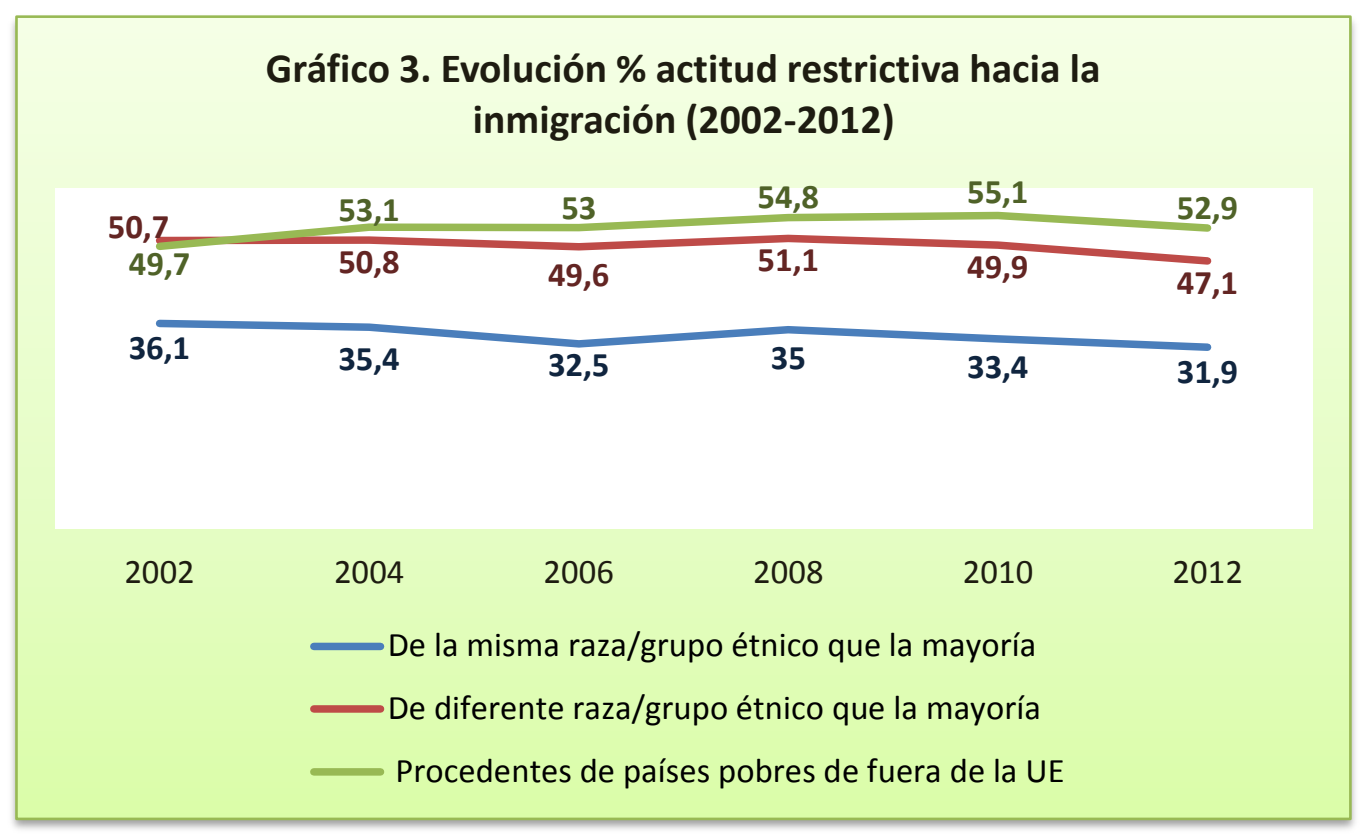

Fuente: elaboración propia a partir de la ESE 2002-2012

En cuanto a la tasa de personas que no contestan (Gráfico 4), ya sea porque dicen no saber o porque rehúsan a hacerlo, es relativamente pequeña (en torno al 3-5\% del total de casos). Este aspecto es importante en la medida en que la medición de las actitudes hacia la inmigración suele obstaculizarse por el sesgo de deseabilidad social: personas que no desean aparecer como xenófobas o racistas porque es considerada una actitud no deseable socialmente, apareciendo una actitud favorable a la inmigración sobrerrepresentada o un porcentaje alto de casos perdidos.

El recurso a indicadores indirectos para medir actitudes xenófobas o racistas ayuda a reducir el impacto del sesgo de deseabilidad social. En este caso, la Encuesta Social Europea no pregunta directamente por actitudes xenófobas o racistas, sino sobre la permisividad que se debería tener ante la entrada de inmigración en función de su origen étnico/racial y procedencia, así como la valoración del efecto de la inmigración en la economía, cultura y condiciones de vida del país receptor.

En cualquier caso, es destacable el hecho de que siempre sean mayores los casos de "no saben/no contestan" en el caso de población inmigrante procedente de países pobres no comunitarios (la inmigración que mayor rechazo produce), seguidos de los inmigrantes de diferente raza/grupo étnico que la mayoría. Por su parte, los porcentajes más bajos de "no saben/no contestan" se dan en la pregunta 
sobre población inmigrante de la misma raza/grupo étnico, el tipo de inmigración que mayor aceptación social tiene. Esto puede indicar que hay personas influidas por el sesgo de deseabilidad social y que han preferido no contestar por no mostrar una actitud reacia a la inmigración de personas con perfiles socioeconómicos más bajos y de origen étnico/racial diferentes.

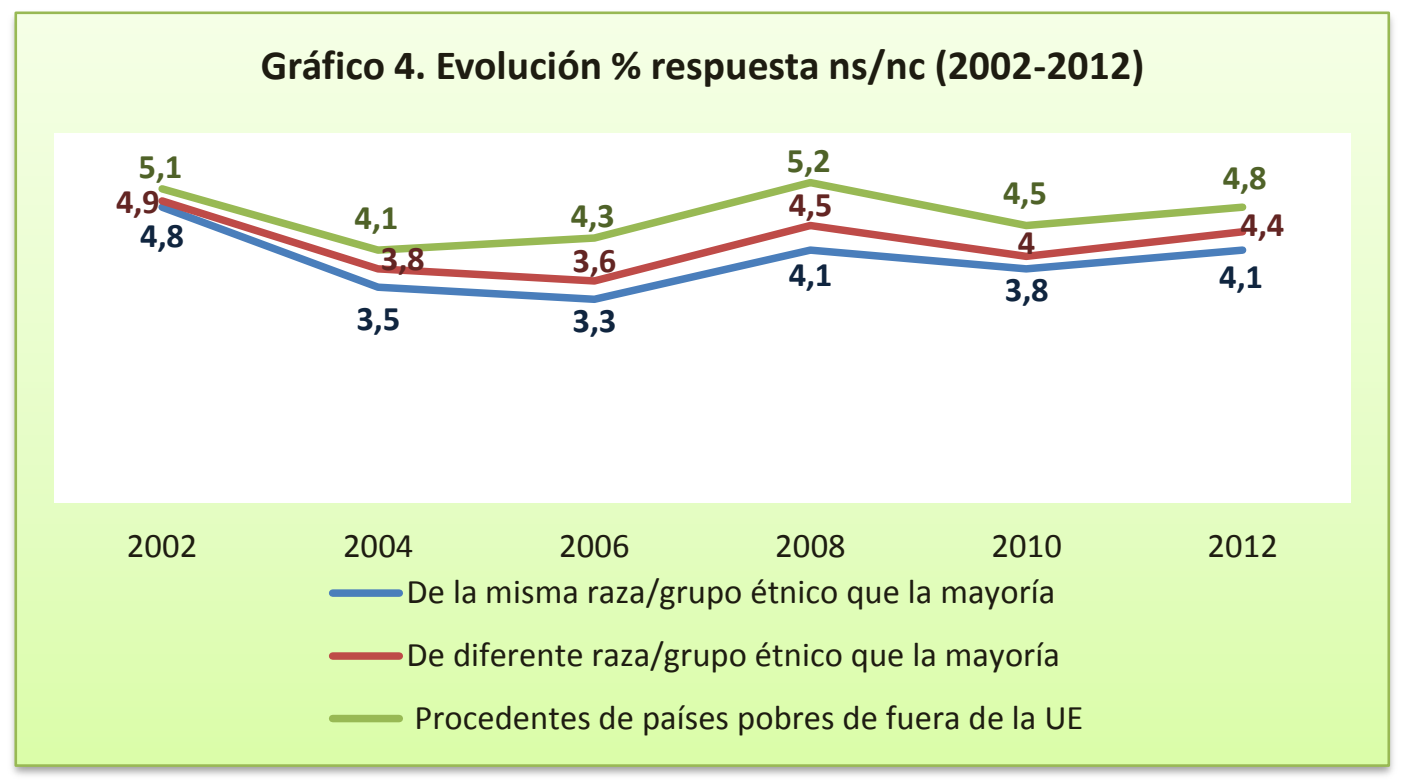

Fuente: elaboración propia a partir de la ESE 2002-2012

\section{B. Valoración del efecto de la inmigración en el país receptor:}

Otras de las variables utilizadas en la investigación son las valoraciones del efecto de la inmigración en la economía y en la cultura del país, así como del impacto que ejerce la población inmigrante en el país como lugar para vivir ${ }^{14}$. Estas preguntas se formulan de forma que los encuestados se posicionen en una escala que oscila entre 0 (efecto negativo en la economía, empobrecimiento de la cultura y empeoramiento del país como lugar para vivir) y 10 (efecto positivo en la economía, enriquecimiento de la cultura y mejoramiento del país como lugar para vivir). De media, los encuestados valoraron mejor el efecto de la inmigración en la cultura $(5,51)$, que en la economía -el peor valorado- $(4,87)$ y en las condiciones de vida del país $(4,94)$.

\footnotetext{
${ }^{14}$ Anexo 1. Tablas I.III y I.IV
} 
Para representarlas gráficamente, se han recodificado las respuestas en tres categorías: efecto negativo, ni negativo/ni positivo (anexo I), y efecto positivo.

La valoración negativa (Gráfico 5) del efecto de la inmigración en la cultura y condiciones de vida del país ha sufrido una tendencia creciente desde 2002 hasta 2010. La valoración negativa del impacto en la economía es más oscilante. En todos los años, a excepción de 2002, el ámbito donde más valoraciones negativas ha recibido el efecto de la inmigración ha sido el de la economía (en torno a un 39$40 \%$ ), seguido de las condiciones de vida del país (37-38\%) y, por último, la cultura (29-30\%). La valoración más negativa de la inmigración se produce en 2010: un $42,3 \%$ de los encuestados consideraron que la inmigración tenía un efecto negativo en la economía de su país, un $39,8 \%$ opinaron lo mismo del impacto de la inmigración en su país como lugar para vivir, así como un 34,8\% en el ámbito cultural.

Por su parte, la evolución de la valoración positiva del impacto de la inmigración en el país receptor (Gráfico 6) muestra una tendencia decreciente hasta 2010 en el ámbito cultural, mientras que la valoración positiva del impacto de la inmigración en las condiciones de vida del país pasa por una ligera tendencia ascendente. La valoración positiva de la economía no sigue una tendencia lineal, alcanza su máximo en 2006 (39,5\%) y su mínimo en 2010 (33,8\%), coincidiendo con el período anterior a la crisis económica y el momento más álgido de ésta.

Donde más valoraciones positivas se registran es en el ámbito cultural: el 49,8\% de los encuestados declararon en 2012 que la inmigración enriquece la cultura de su país. Por su parte, las valoraciones positivas del impacto de la inmigración en la economía y de las condiciones de vida del país son bastante menores $(38,3 \%$ y $36,1 \%$ respectivamente, en 2012 ).

Por último, los casos posicionados en los valores centrales de la escala de valoración (Gráfico 7) han sufrido una tendencia decreciente en los tres ámbitos valorados desde 2002 hasta 2010, lo que indica una mayor polarización en la valoración del efecto de la inmigración. 


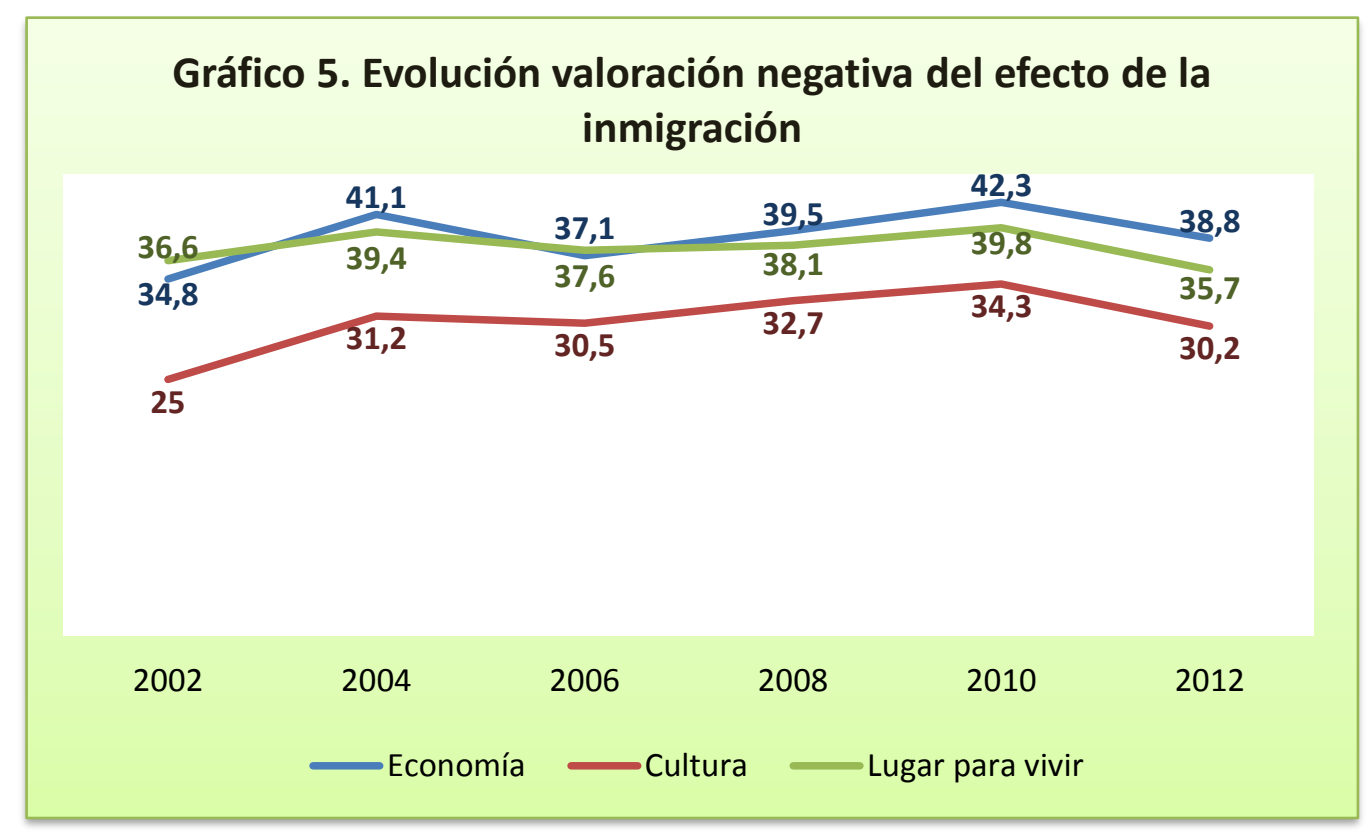

Fuente: elaboración propia a partir de la ESE 2002-2012

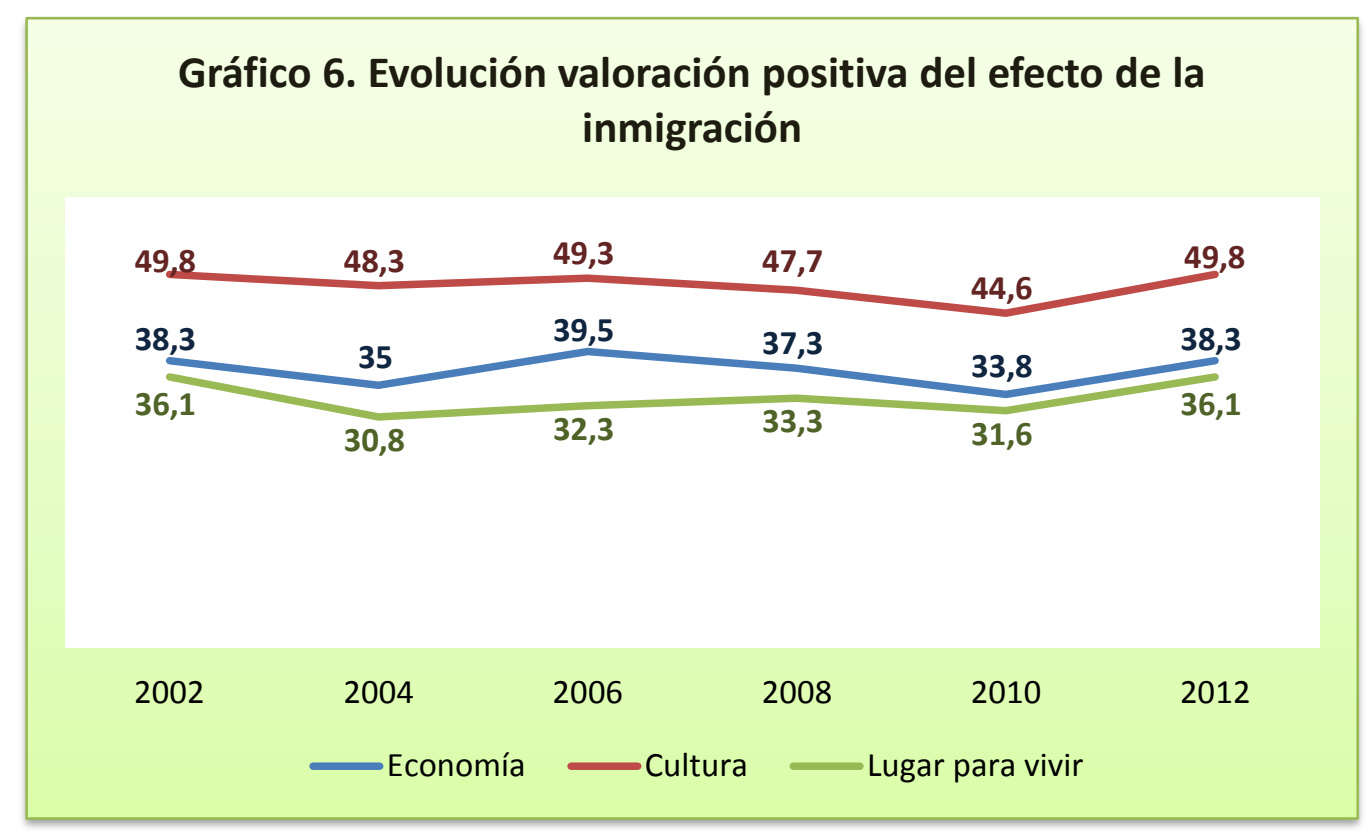

Fuente: elaboración propia a partir de la ESE 2002-2012 


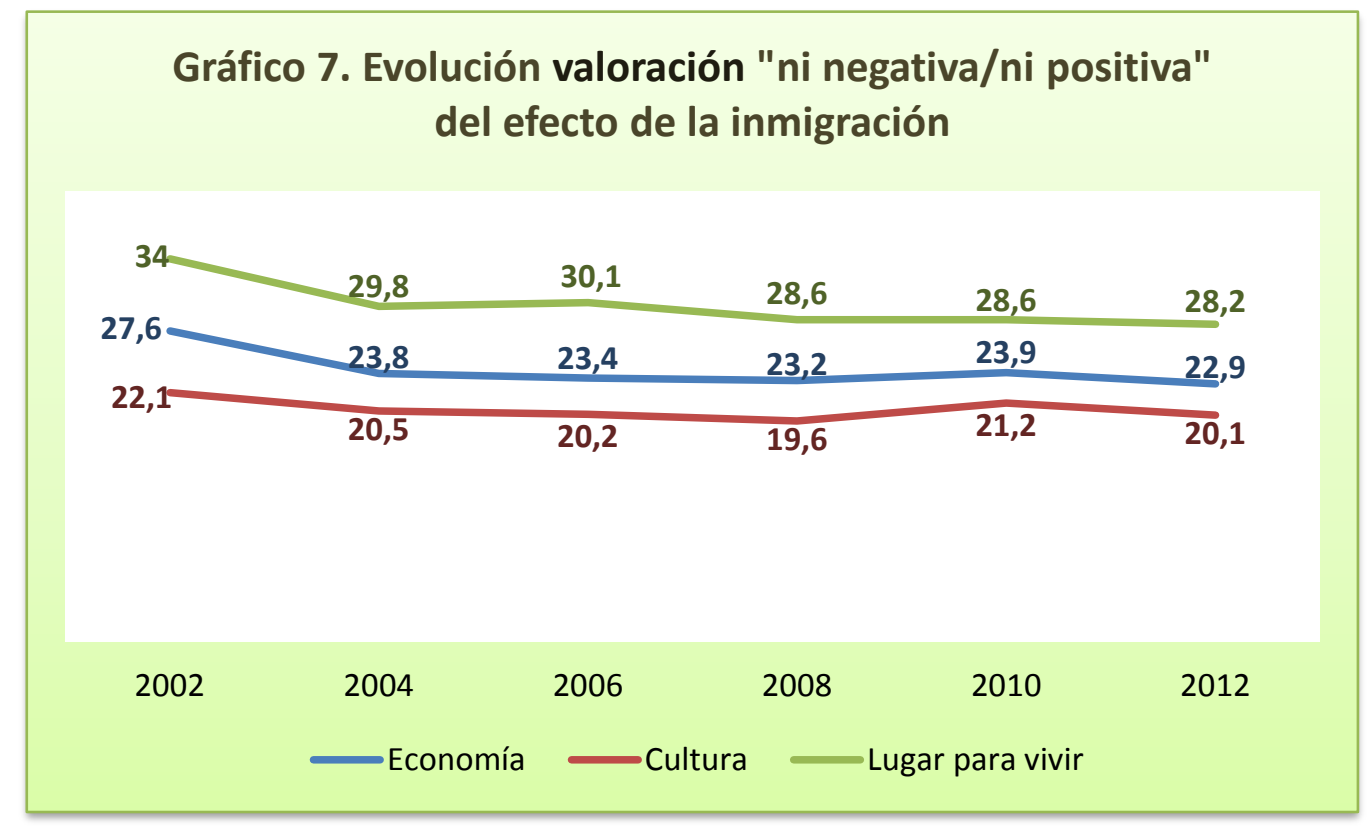

Fuente: elaboración propia a partir de la ESE 2002-2012

\section{PERFIL DE LA ACTITUD RESTRICTIVA HACIA LA INMIGRACIÓN EN EUROPA:}

\section{A. Resultados del análisis bivariante:}

Tras el análisis bivariante a partir de las tablas de contingencia (ANEXO 2) y las pruebas Chi-cuadrado y $\mathrm{V}$ de Cramer, se ha obtenido un perfil aproximado de las personas que mantienen una actitud restrictiva hacia la inmigración procedente de países pobres de fuera de la Unión Europea.

Desde el punto de vista socioeconómico, el rechazo hacia este tipo de inmigración es más frecuente entre aquellas personas de avanzada edad, nivel de estudios bajos, pocos ingresos, clase social baja o media-baja, inactivos desde el punto de vista laboral (a excepción de los estudiantes), y aquellos que tienen profesiones de carácter manual y/o poco cualificados dentro de los activos. También es más frecuente entre las personas que ideológicamente se ubican en la derecha y extrema derecha, o que no contestan sobre su ideología, que desconfían de la gente y de las instituciones, que no están interesados en la política y que mantienen actitudes muy 
conservadoras en relación a personas con orientaciones homosexuales y que no conceden importancia a la protección de los derechos de las minorías. Por último, el rechazo hacia este tipo de inmigración es más frecuente entre quienes valoran de forma negativa la situación económica de su país, la labor del gobierno nacional, el funcionamiento de la democracia, la integración europea, y entre quienes creen que las condiciones de vida de su país van a peor y se sienten inseguros en sus barrios.

\section{Perfil socioeconómico ${ }^{15}$ :}

i. Género: mujeres y hombres muestran una actitud similar ante la inmigración. En ambos casos, la actitud restrictiva hacia la inmigración gira en torno al $53 \%$ (52,7\% en hombres, 53,1\% en mujeres). La prueba de Chi-cuadrado muestra que no hay una relación estadísticamente significativa entre el género y la actitud hacia la inmigración.

ii. Edad: la actitud restrictiva hacia la inmigración es más frecuente conforme aumenta la edad. Los mayores de sesenta años es el grupo de edad que mayor porcentaje de actitud restrictiva registra (60,9\%), frente al grupo de edad más joven, entre 15 y 29 años (44,9\%).

iii. Estado civil: la actitud de rechazo hacia la inmigración es mayoritaria en viudos/as (64,8\%), divorciados/as y separados/as $(57,2 \%)$ y casados/as y parejas de hecho (54,1\%). Mientras que en la población soltera, la actitud mayoritaria hacia la inmigración es la permisiva (54,6\%).

iv. Nivel de estudios: la actitud restrictiva hacia la inmigración disminuye conforme aumenta el nivel de estudios. Los que tienen estudios superiores son los que menor actitud restrictiva registran $(43,4 \%)$ frente a los que tienen estudios primarios o no tienen estudios $(63,7 \%)$, que son los que mayor rechazo profesan hacia la entrada de población inmigrante.

v. Situación laboral: Jubilados/as, desempleados/as y amas de casa presentan de forma mayoritaria una actitud restrictiva hacia la inmigración (61,8\%, $56,1 \%$ y $54,2 \%$ respectivamente); mientras que, estudiantes y trabajadores remunerados muestran una actitud mayoritariamente permisiva hacia la entrada de población inmigrante $(61,3 \%$ y $50,1 \%$ respectivamente).

\footnotetext{
${ }^{15}$ Tablas de contingencia en Anexo 2.1.
} 
vi. Ocupación: las profesiones que requieren mayor cualificación y formación, como la de profesionales y gerentes, son los que menor porcentaje de actitud restrictiva presentan $(41,3 \%$ y $44,9 \%$ respectivamente), frente a las profesiones más manuales y/o menos cualificada, que son las que mayor actitud de rechazo registran: Operadores de instalaciones y máquinas $(61,7 \%)$, Artesanos (60\%), Ocupaciones elementales (59\%) y Trabajadores expertos en agricultura, pesca y forestal $(59,3 \%)$.

vii. Nivel de ingresos: las personas con ingresos bajos registran los porcentajes más altos de actitud restrictiva (57,2\%). La actitud de rechazo se reduce conforme aumentan los ingresos, siendo los más permisivos hacia la inmigración los que más ingresan (56,3\% de actitud permisiva).

viii. Clase social subjetiva: la actitud restrictiva hacia la inmigración es más frecuente entre las capas sociales más bajas, y menos entre las más altas. Las personas que se ubican en lo más bajo de la escala social son los que mayor actitud restrictiva tienen hacia la inmigración $(63,9 \%)$, reduciéndose hasta llegar a los que se ubican en lo más alto de la sociedad $(47,2 \%)$.

ix. Nacionalidad: la actitud restrictiva hacia la inmigración es mayor entre los nacionales del país donde habita $(53,4 \%)$ que entre los que no tienen la nacionalidad $(41,9 \%)$.

$x$. Lugar de residencia: las personas que habitan a las afueras o en los suburbios de una gran ciudad son los que menor rechazo registran hacia la entrada de población inmigrante $(46,6 \%)$, frente a los que viven en una gran ciudad $(54,2 \%)$, que son los que mayor actitud restrictiva registran, seguidos de quienes viven en una ciudad de tamaño medio, en un pueblo o en el campo (en torno al 53\%).

\section{Perfil político y cultural ${ }^{16}$ :}

i. Ideología: las personas de derecha son más reacias a la entrada de población inmigrante que las ubicadas en el centro e izquierda. El porcentaje más alto de actitud restrictiva hacia la inmigración se da entre quienes se ubican en la extrema derecha $(62,2 \%)$, seguidos de quienes no contestan

\footnotetext{
${ }^{16}$ Tablas de contingencia en Anexo 2.2
} 
sobre su ideología (60,1\%). En el otro extremo, el porcentaje más bajo de rechazo hacia la inmigración se da entre quienes se ubican en el centroizquierda $(42,9 \%)$, seguidos de quienes se ubican en la extrema izquierda $(48,6 \%)$.

ii. Confesión religiosa: judíos y ortodoxos del este, son los grupos confesionales que mayor rechazo profesan a la entrada de población inmigrante $(74,8 \%$ y $65 \%$, respectivamente), seguidos por musulmanes $(52,6 \%)$ y católicos $(52,2 \%)$. Los más permisivos hacia la inmigración son las personas que siguen religiones orientales $u$ otras no cristianas $(66,5 \%)$, otras confesiones cristianas $(53,8 \%)$ y protestantes $(50,5 \%)$.

iii. Interés por la política: las personas más interesadas por la política mantienen actitudes más permisivas hacia la inmigración $(52,3 \%)$ que quienes no están interesados (42,8\%).

iv. Confianza en la gente: las personas más desconfiadas registran los porcentajes más altos de actitud restrictiva, y viceversa. El porcentaje más alto de actitud restrictiva se da entre quienes no confían en absoluto en la gente $(63,9 \%)$, mientras que el más bajo se da entre quienes se declaran muy confiados $(43,3 \%)$.

v. Confianza en las instituciones: las personas que más desconfían de las instituciones muestran los porcentajes más altos de rechazo hacia la inmigración, y viceversa. Los que desconfían absolutamente del sistema judicial y los partidos políticos son los que mayor actitud restrictiva hacia la inmigración registran (61,3\% y 59,1\% respectivamente), frente a los que dicen confiar absolutamente ( $44 \%$ en ambos casos).

vi. Protección de los derechos de las minorías: las personas que creen que es muy importante para una democracia proteger los derechos de las minorías registran el porcentaje más bajo de rechazo hacia la inmigración $(48,2 \%)$. El porcentaje de actitud restrictiva hacia la inmigración va aumentando conforme se le resta importancia a la protección de los derechos de las minorías, hasta alcanzar su máximo, entre quienes creen que no es nada importante $(73,3 \%)$.

vii. Respeto por las personas de orientación homosexual: las personas que creen que las personas homosexuales deben tener libertad para vivir como quieran son también las más permisivas hacia la inmigración $(60,9 \%$ de 
actitud permisiva). En el otro extremo, el porcentaje más alto de rechazo hacia la inmigración se da entre quienes son muy contrarios a dejar que las personas homosexuales tengan libertad para vivir como quieran $(69,8 \%)$.

\section{Valoración actualidad política, económica y social ${ }^{17}$ :}

i. Valoración situación económica y política del país: las personas que dicen estar más satisfechas con la situación económica y política de su país se muestran más permisivas hacia la inmigración, que quienes dicen estar insatisfechas. Así, quienes están muy insatisfechos con la situación económica de su país, la labor del Gobierno de la nación, y el funcionamiento de la democracia, son los que mayor porcentaje de rechazo hacia la inmigración registran (en torno al 60\% en los tres casos), reduciéndose de forma progresiva hasta alcanzar el porcentaje más bajo (en torno al 40\%), registrado en quienes dicen estar muy satisfechos.

ii. Valoración integración europea: las personas que opinan que la integración europea ha ido demasiado lejos muestran un porcentaje mayor de rechazo hacia la inmigración (63,9\%) que quienes piensan que es adecuada (50,5\%) y entre quienes creen que la integración debería ir más lejos $(41,6 \%)$.

iii. Valoración condiciones de vida de la mayoría de los ciudadanos de su país: quienes creen que la vida de la mayoría de los ciudadanos va a peor registran porcentajes más altos de actitud restrictiva hacia la inmigración que quienes piensan que no es así. Los que están muy de acuerdo con esa afirmación, registran el porcentaje más alto de rechazo hacia la inmigración $(62,8 \%)$, frente a quienes están muy en desacuerdo (43,5\%).

iv. Valoración seguridad de su barrio: las personas que dicen vivir en un barrio inseguro o muy inseguro muestran mayor rechazo hacia la inmigración (61\%) que quienes dicen vivir en uno seguro o muy seguro $(50,1 \%)$.

Todas las variables consideradas, a excepción del género, han mostrado una asociación estadísticamente significativa (para un nivel de significación del 0,01) con

\footnotetext{
${ }^{17}$ Tablas de contingencia en Anexo 2.3
} 
la variable dependiente: "Actitud hacia la inmigración procedente de países pobres de fuera de la UE". Las diferencias de porcentajes que se pueden apreciar en las tabas de contingencia (ANEXO X) y los valores Chi-cuadrado y V de Cramer (tabla 1), han mostrado que las variables político-culturales y de valoración de la actualidad política, económica y social, mantienen una considerable asociación con la variable dependiente, así como la ocupación, el nivel de estudios, la situación laboral y la edad, dentro de las variables socioeconómicas.

Tabla 1. Valores Chi-cuadrado y V de Cramer en el cruce con la variable dependiente: Actitud hacia la inmigración procedentes de paises pobres de fuera de la UE

\begin{tabular}{|c|c|c|}
\hline VARIABLES INDEPENDIENTES & $\begin{array}{c}\text { CHI- } \\
\text { CUADRADO }\end{array}$ & V DE CRAMER \\
\hline \multicolumn{3}{|l|}{ Perfil socioeconómico } \\
\hline Ocupación & 875,661 & 0,138 \\
\hline Nivel de estudios & 958,242 & 0,136 \\
\hline Situación laboral & 894,347 & 0,132 \\
\hline Edad & 745,175 & 0,12 \\
\hline Estado civil & 667,785 & 0,114 \\
\hline Clase social subjetiva & 527,067 & 0,102 \\
\hline Ingresos & 369,449 & 0,094 \\
\hline Ciudadanía & 108,632 & 0,046 \\
\hline Lugar residencia & 99,768 & 0,044 \\
\hline Sexo & 0,613 & 0,003 \\
\hline \multicolumn{3}{|l|}{ Perfil político-cultural } \\
\hline Gays y lesbianas & 2233,743 & 0,212 \\
\hline Confesión religiosa & 756,943 & 0,154 \\
\hline Confianza en la gente & 1104,717 & 0,146 \\
\hline Derechos de las minorías & 1054,964 & 0,145 \\
\hline Confianza en el sistema judicial & 812,908 & 0,126 \\
\hline Ideología & 736,933 & 0,119 \\
\hline Confianza en los partidos políticos & 717,791 & 0,119 \\
\hline Interés por la política & 468,145 & 0,095 \\
\hline \multicolumn{3}{|l|}{$\begin{array}{l}\text { Valoración actualidad política, } \\
\text { social y económica }\end{array}$} \\
\hline Integración europea & 1365,319 & 0,172 \\
\hline Condiciones de vida del país & 1017,093 & 0,141 \\
\hline Situación económica & 999,082 & 0,14 \\
\hline Funcionamiento de la democracia & 760,186 & 0,123 \\
\hline Labor del gobierno & 632,238 & 0,112 \\
\hline Seguridad de su barrio & 450,594 & 0,094 \\
\hline
\end{tabular}




\section{B. Resultados del análisis de control por terceras variables:}

Determinadas variables consideradas en este estudio como independientes (ingresos, el estado civil, la situación laboral, el lugar de residencia, etc.) pueden estar sesgadas o influenciadas por terceras variables en su relación con la dependiente. Por ello, se ha procedido a realizar tablas de contingencia de tres variables para analizar el comportamiento de algunas de las variables independientes en su actitud hacia la inmigración controladas por terceras variables (se ha optado por presentar sólo los resultados más significativos, porque al contar con un número alto de variables independientes se puede producir un sinfín de combinaciones con terceras variables). Se busca conocer si la relación entre las variables independientes y la dependiente se mantiene firme a pesar de la introducción de terceras variables, así como especificar las condiciones en las que se produce la relación entre aquéllas y analizar el efecto conjunto de dos variables independientes sobre la dependiente.

\section{$\underline{\text { Control por la variable edad }}^{18}$ :}

\section{- Ingresos:}

Los grupos de edad considerados cuentan con unas medianas de ingresos diferentes: los mayores de sesenta son los que ingresan menos (tramo 4 de ingresos), seguidos de los más jóvenes (tramo 5). Por su parte, los grupos de edad entre 30 y 59 años son los que cuentan con una mediana de ingresos más alta (tramo 6).

La relación entre ingresos y la variable dependiente muestra que la frecuencia de rechazo hacia la inmigración crece conforme se reducen los ingresos. Sin embargo, al controlar esta relación por la edad, se puede observar que dicha tendencia no se produce entre los más jóvenes (15-29 años): no hay diferencias porcentuales significativas en los diferentes tramos de ingresos, ni se sigue tendencia alguna (según el estadístico Chi-cuadrado, no se da una relación estadísticamente significativa entre ambas variables). En el resto de grupos de edad, la tendencia se

\footnotetext{
${ }^{18}$ Tablas de contingencia en Anexo 3.A
} 
mantiene: el rechazo es mayor conforme se reducen los ingresos, si bien las diferencias porcentuales entre los diferentes tramos de ingresos son bastante más acentuadas en los mayores de sesenta años.

Esto indica que la variable ingresos no afecta por igual a todos los grupos de edad: en los más jóvenes los ingresos no producen una variación significativa en su actitud hacia la inmigración, mientras que sí lo hacen en el resto de edades, con más intensidad entre los mayores de sesenta años.

\section{$\underline{\text { Control por nivel educativo }}^{19}$ :}

\section{- Edad:}

¿Es posible que el nivel educativo introduzca un sesgo en la relación entre la edad y la actitud hacia la inmigración, en la medida en que las personas mayores tienen menos nivel educativo que los más jóvenes ${ }^{20}$.

Según el cruce de variables Edad y Actitud hacia la inmigración, el rechazo hacia la entrada de inmigrantes aumenta conforme lo hace la edad de los encuestados. Sin embargo, al controlarla por el nivel educativo, la tendencia no se mantiene entre los que tienen estudios superiores: la actitud permisiva es mayoritaria en todos los grupos de edad (incluso entre los mayores) y las diferencias porcentuales entre las categorías son mínimas (7,9\% entre los más jóvenes y los mayores de sesenta). Por el contrario, entre los que tienen estudios primarios o no tienen estudios, las diferencias entre los distintos grupos de edad son muy acentuadas (un $21,8 \%$ de diferencia entre los más jóvenes y los mayores de sesenta) y el rechazo es mayoritario en todos los grupos de edad con excepción de quienes tienen entre 15 y 29 años. Por su parte, entre aquellos que tienen estudios secundarios, la actitud restrictiva aumenta conforme lo hace la edad, aunque con diferencias porcentuales más reducidas (15,1\% entre los más jóvenes y los mayores de sesenta).

\footnotetext{
${ }^{19}$ Tablas de contingencia en Anexo 3.B

${ }^{20}$ Media de edad: $15-29$ años $(12,8), 30-44(13,9), 45-59(12,9)$ y mayores de $60(10,9)$
} 
Todo esto indica que las diferencias producidas por la edad en la actitud que se mantiene hacia la inmigración varían de forma muy significativa según el nivel educativo de los encuestados. Se puede afirmar entonces que la relación entre la edad y la actitud hacia la inmigración no es del todo independiente al nivel educativo de los encuestados.

\section{- Ingresos:}

Considerando que los ingresos son más altos entre los encuestados que tienen estudios superiores y que, por el contrario, son más bajos entre quienes no tienen estudios o tienen estudios primarios, ${ }^{21}$ y que la actitud hacia la inmigración es más permisiva entre aquellos que más ingresan, y viceversa, ¿es posible que esta relación esté afectada por el nivel educativo de los encuestados?

En efecto, entre aquellos que tienen estudios superiores, la diferencias de ingresos no produce mucha variación en la actitud hacia la inmigración: ésta es permisiva de forma mayoritaria en todos los casos (ya tengan ingresos bajos, medios o altos) y no sigue una tendencia lineal por la cual la actitud restrictiva aumente conforme se reducen los ingresos. Por el contrario, entre quienes tienen estudios primarios o no tienen estudios, si se observa esta tendencia (los que ingresan menos son mucho más reacios a la inmigración que quienes ingresan más). El rechazo es además, mayoritario en todos los niveles de ingresos.

Se puede afirmar entonces que la variable ingresos tiene más incidencia en la actitud hacia la inmigración de los encuestados con menos estudios, y poca o ninguna entre los que tienen mayor nivel educativo.

\section{- Situación laboral:}

El cruce de las variables Situación laboral y Actitud hacia la inmigración mostraba que jubilados, desempleados y amas de casa mantienen de forma mayoritaria una

\footnotetext{
${ }^{21}$ Mediana de ingresos: Estudios primarios o sin estudios (tramo 3), estudios secundarios (tramo 5) y estudios superiores (tramo 7).
} 
actitud restrictiva hacia la inmigración, mientras que estudiantes y trabajadores son de forma mayoritaria permisivos ante ésta.

Al controlar esta relación por el nivel educativo de los encuestados, se puede observar que, con excepción de los estudiantes (que mantiene firme su tendencia, en torno al 34-38\% de actitud restrictiva), el resto de categorías se ven afectadas al introducir el nivel educativo: el rechazo hacia la inmigración se reduce de forma drástica en todas las categorías conforme aumenta el nivel educativo de los encuestados. Entre los que tienen estudios superiores, todas las situaciones laborales muestran una actitud permisiva de forma mayoritaria, con excepción de los jubilados/as e incapacitados/as (aunque la actitud restrictiva que registran es baja, del 51,7\%). Por el contrario, entre los encuestados sin estudios o estudios primarios, la actitud es restrictiva en todas las categorías laborales, con excepción de los estudiantes.

Por lo que se puede afirmar que la relación que mantiene la variable dependiente y la situación laboral, depende en buena medida del nivel educativo de los encuestados. Sólo los estudiantes mantienen firme su tendencia. Los jubilados/as e incapacitados/as, si bien muestran una actitud restrictiva de forma mayoritaria en todos los niveles educativos, esta se reduce de forma drástica (en 16 puntos porcentuales) al aumentar el nivel educativo de los encuestados.

\section{Control por ingresos $^{22}$ :}

\section{- Situación laboral:}

La relación que mantiene la situación laboral con la variable dependiente puede estar influenciada por los ingresos en la medida en que se percibe una importante diferencia económica de los encuestados en función de su situación laboral: jubilados/as e incapacitados/as para el trabajo y desempleados/as, son las categorías con una mediana de ingresos más baja (tercer tramo de ingresos en ambos casos), seguidos de quienes se dedican al cuidado del hogar y/o familiares

\footnotetext{
${ }^{22}$ Tablas de contingencia en Anexo 3.C
} 
(tramo 4). Por el contrario, los trabajadores remunerados son quienes más ingresan (tramo 6), seguidos de los estudiantes (tramo 5).

Las tres categorías que menos ingresan, jubilados/as e incapacitados/as, desempleados/as y amas de casa son las únicas que se ven afectadas por la variable ingresos: la actitud de rechazo hacia la inmigración aumenta de forma muy considerable conforme se reducen los ingresos de los encuestados. Trabajadores y estudiantes, por el contrario, no sólo no mantienen esa tendencia lineal sino que además, presentan diferencias porcentuales reducidas en los diferentes tramos de ingresos.

$\underline{\text { Nivel de estudios e ingresos }}^{23}$ :

\section{- Ocupación:}

En las distintas categorías ocupacionales se producen diferencias en el nivel educativo de los encuestados. Los profesionales y gerentes son las dos categorías que mayor nivel educativo de media tienen (16,3 y 14,7 años de estudios terminados, respectivamente), seguidos de las ocupaciones militares $(13,7)$ y técnicos y profesionales de nivel medio $(13,8)$. En el otro extremo, los que registran un nivel educativo medio más bajo son las ocupaciones más manuales y/o que precisan de menos cualificación, como los trabajadores en agricultura, pesca y forestal $(9,3)$, las ocupaciones elementales y operadores de instalaciones y máquinas (10) y artesanos $(11,1)$. Entre medio, están el personal de apoyo administrativo y los trabajadores de los servicios y ventas, con una media de 12 años de estudios completados.

Las categorías ocupacionales con una mediana más alta de ingresos son los profesionales, gerentes y militares (tramo 7 de ingresos), seguidos de los técnicos y profesionales de nivel medio (tramo 6) y personal de apoyo administrativo (tramo 5). Los que tienen una mediana de ingresos más bajos son, por su parte, los trabajadores expertos en agricultura, pesca y forestal y los que tienen ocupaciones

\footnotetext{
${ }^{23}$ Tablas de contingencia en Anexo 3. D
} 
elementales (tramo 3), seguidos por artesanos, operadores de instalaciones y máquinas y trabajadores de servicios y ventas (tramo 4).

Las categorías ocupacionales con mayor nivel educativo coinciden con las más permisivas hacia la inmigración, así como las que tienen el nivel educativo más bajo con las más restrictivas. Lo mismo sucede con los ingresos: con excepción de los militares, los que mayores ingresan son los que muestran actitudes más permisivas hacia la inmigración, y viceversa.

\section{Resultados del análisis multivariante: árboles de clasificación}

\section{CHAID}

El primer árbol de clasificación (árbol nำ1) segmenta la muestra en función de la edad, situación laboral y clase social subjetiva de los encuestados. El árbol tiene un total de 26 nodos, de los cuales 16 son terminales y cuenta con tres niveles de segmentación. El porcentaje total de casos clasificados correctamente es de un $56,9 \%$, siendo la estimación del riesgo de 0,431.

La mejor variable predictora es la situación laboral, segmentando la muestra en cuatro nodos: el más numeroso, trabajadores/as remunerados (25.344 casos), jubilados/as o incapacitados/as para el trabajo (8.509), desempleados/as y amas de casa (8.394) y, el menos numeroso, estudiantes (1.739).

El porcentaje más alto de rechazo a la inmigración se da entre los/as jubilados/as o incapacitados/as para el trabajo de clase baja y mayores de 44 años $(67,1 \%)$; mientras que el porcentaje más alto de actitud permisiva se da entre estudiantes de clase media y alta $(62,3 \%)$.

- Trabajadores remunerados, cuya categoría pronosticada es la actitud permisiva $(50,1 \%)$. Los trabajadores son segmentados por la clase social, diferenciando entre clase baja, media y alta. Este último es un nodo terminal, mientras que los trabajadores de clase baja y media son clasificados en función de la edad. El porcentaje más alto de actitud restrictiva se da entre los trabajadores de clase baja mayores de 44 años $(62,7 \%)$, mientras que la 
actitud permisiva más alta se encuentra entre los trabajadores de clase media de entre 15 y 44 años $(51,2 \%)$.

- Desempleados/as y amas de casa son agrupados bajo un mismo nodo, siendo la categoría pronosticada la actitud restrictiva $(55,1 \%)$. Este nodo es segmentado por la clase social, diferenciando entre clase baja (nodo terminal), media (segmentados por la edad) y alta (diferenciando entre desempleados y amas de casa). El porcentaje más alto de actitud restrictiva se da entre aquellos desempleados/as y amas de casa de clase baja (60,6\%), mientras que la actitud permisiva más alta se da entre las amas de casa de clase alta $(52,6 \%)$.

- Jubilados/as o incapacitados/as para el trabajo, es el nodo que presenta el porcentaje de actitud restrictiva más alta de todos los grupos $(61,7 \%)$. Son segmentados en función de la clase social, diferenciando entre clase baja, media y alta. Estos dos últimos son nodos terminales. Los/as jubilados/as o incpacitados/as de clase baja son clasificados por la edad, encontrándose el porcentaje más alto de actitud restrictiva entre los mayores de 44 años. La actitud restrictiva más baja de esta categoría laboral se da entre aquellos de clase alta $(55,4 \%)$.

- Estudiantes. presentan el porcentaje de actitud permisiva más alta de todos los grupos (61,3\%), y son segmentados en dos nodos: clase baja, con una actitud permisiva del 53,1\%; y clase media y alta, agrupados bajo un mismo nodo $(62,3 \%$ de actitud permisiva). 


\section{Árbol de clasificación no 1: clase social subjetiva, situación laboral y edad}

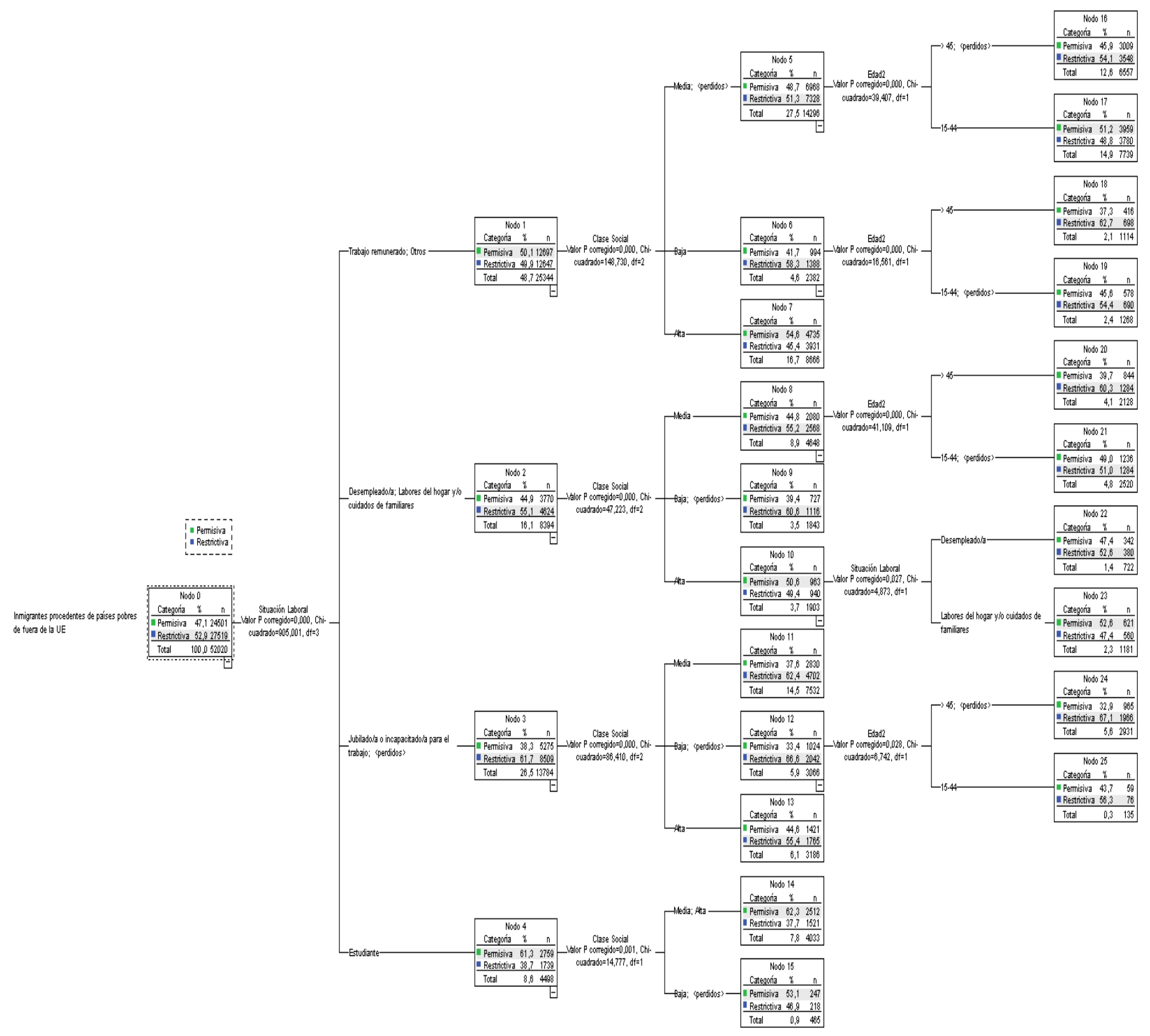


El segundo árbol de clasificación (árbol no2) tiene como variables independientes el nivel educativo, los ingresos y la ideología. Está compuesto por 30 nodos, de los cuales 20 son terminales y tiene tres niveles de segmentación. El riesgo estimado es de 0,419 y el porcentaje total de casos correctamente pronosticados es de $58,1 \%$, y del $80,9 \%$ en el caso de la categoría: actitud restrictiva hacia la inmigración.

La principal variable predictora es el nivel educativo de los encuestados. Se diferencian tres nodos: el más numeroso, es el de estudios secundarios (más de 29.000 casos), seguidos de los que tienen estudios superiores (más de 15.0000), y por los que tienen estudios primarios o no tienen (casi 7.000 casos).

El porcentaje más alto de actitud restrictiva se da entre los encuestados sin estudios o con estudios primarios e ingresos medios y bajos $(64,4 \%)$, mientras que el porcentaje más alto de actitud permisiva se encuentra entre los encuestados con estudios superiores, de izquierda con ingresos medio-altos y altos $(74,9 \%)$.

- Estudios primarios o sin estudios: la categoría pronosticada de este nodo es la actitud restrictiva $(63,7 \%)$ y es segmentado en función de los ingresos. El nodo que cuenta con el porcentaje más alto de actitud restrictiva son los que tienen estudios primarios o sin estudios, e ingresos medio-bajos y bajos (64,4\%).

- Estudios secundarios: la categoría pronosticada de este nodo es la actitud restrictiva hacia la inmigración $(55,3 \%)$, y es segmentada en función de la ideología. Diferencia entre los encuestados de izquierda, de centro y agrupa en un mismo nodo a los que no contestan sobre su ideología y los de derecha. En los tres casos, el algoritmo segmenta la muestra por los ingresos. El porcentaje más alto de actitud restrictiva dentro de los encuestados con estudios secundarios son los que no contestan sobre su ideología y de derecha, con ingresos medios y bajos $(60,8 \%)$.

- Estudios superiores: la categoría pronosticada de este nodo es la actitud permisiva hacia la inmigración $(56,6 \%)$ y es segmentada en función de la ideología diferenciando entre los encuestados de izquierda, los de centro, y agrupando en un mismo nodo a los que no contestan sobre su ideología y los de derecha. En los tres casos, el algoritmo segmenta la muestra por el nivel de ingresos. El porcentaje de actitud permisiva hacia la inmigración más alta 
se da entre los encuestados de izquierda con ingresos medio-altos y altos $(74,9 \%)$, y la actitud restrictiva más alta entre los de derecha y que no contestan sobre su ideología con ingresos bajos $(57,5 \%)$.

\section{Árbol de clasificación no 2: nivel educativo, ingresos e ideología}

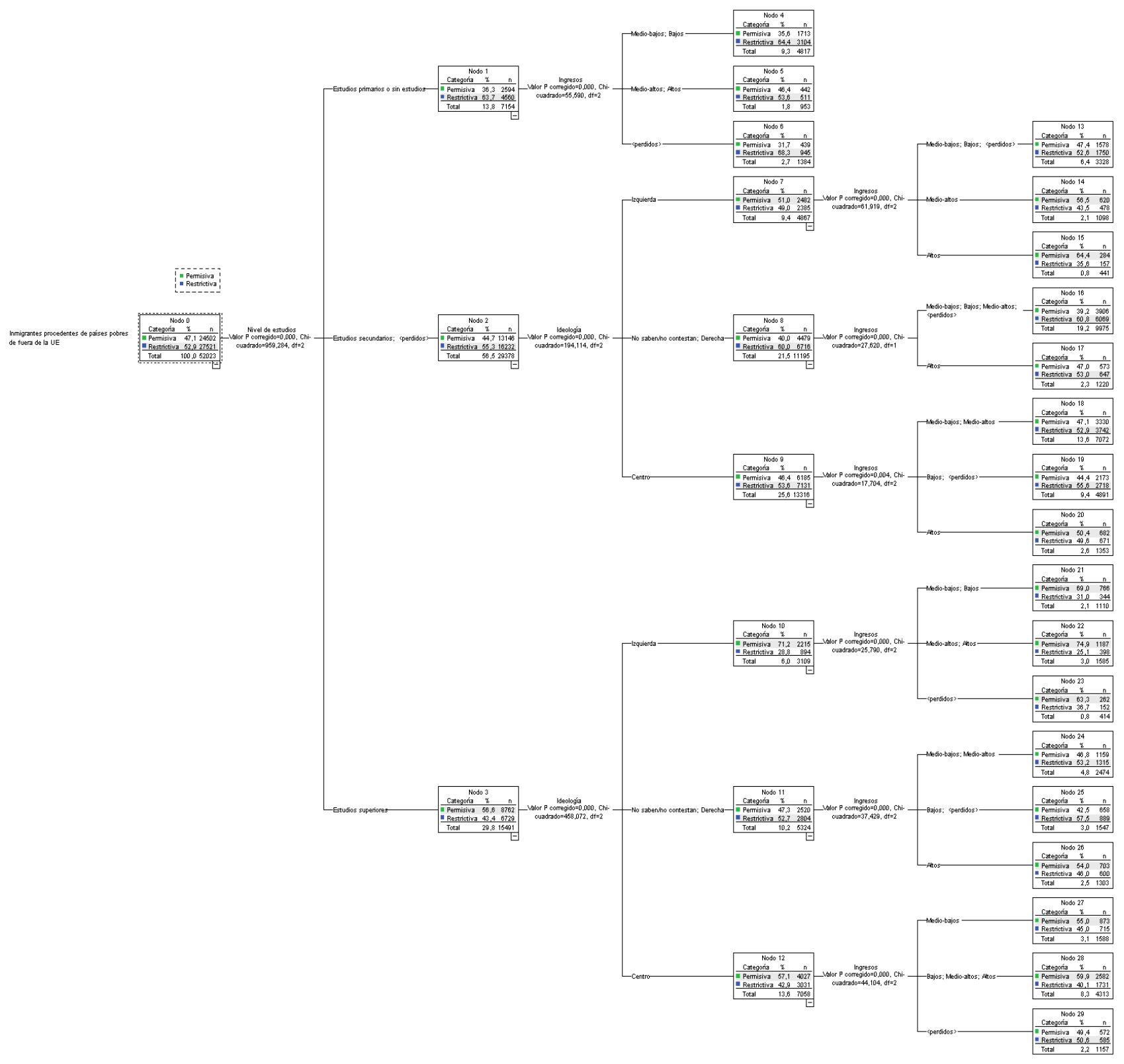

El tercer árbol de clasificación (árbol no3) tiene como variables independientes la confesión religiosa, la edad y la ideología. Está compuesto por un total de 37 nodos, de los cuales 23 son terminales, y cuenta con tres niveles de segmentación. El 
porcentaje total de casos clasificados correctamente es de un $58,7 \%$, y de un $71,5 \%$ en la categoría de actitud restrictiva hacia la inmigración, y la estimación del riesgo es de 0,413 .

La principal variable predictora es la confesión religiosa, clasificando la muestra en cinco grandes segmentos (entre paréntesis, el porcentaje de actitud restrictiva): musulmanes y católicos (52,2\%), religiones orientales y otras no cristianas $(33,5 \%)$, protestantes y otras cristianas $(49,4 \%)$, judíos $(74,8 \%)$ y ortodoxos $(65 \%)$. El porcentaje más alto de actitud restrictiva se encuentra entre los judíos que no contestan sobre su ideología y de derecha $(81,9 \%)$, mientras que el porcentaje de actitud permisiva más alta se da entre los que siguen religiones orientales y otras no cristianas menores de 45 (72,3\%), y protestantes y de otras confesiones cristianas, de izquierdas y menores de $45(71,6 \%)$.

- Confesiones protestantes y otras cristianas: es el segmento más numeroso (más de 26.000 casos) y la categoría pronosticada es la actitud permisiva hacia la inmigración (50,6\%). La primera variable predictora de este grupo es la ideología (entre paréntesis la actitud restrictiva), diferenciando entre aquellos que se declaran de izquierda (35,8\%), de centro $(47,8 \%)$, los que no contestan sobre su ideología $(60,8 \%)$ y los de derecha $(54,4 \%)$. En todos estos grupos el algoritmo segmenta en función de la edad: los que presentan un mayor porcentaje de actitud restrictiva son los que no contestan sobre su ideología mayores de 44 años $(66,6 \%)$.

- Confesiones musulmanas y católica: ambas confesiones son agrupadas en el mismo nodo (el segundo más numeroso), y la categoría pronosticada es la actitud restrictiva (52,2\%). La principal variable predictora de este grupo es la edad: los mayores de 44 años tienen una actitud restrictiva mayor que los más jóvenes $(57,2 \%$ y $45,2 \%$ respectivamente). La muestra sigue segmentándose como sigue: entre los que tienen de 15 a 44 años, se diferencian dos grupos en función de que sean musulmanes o católicos (la actitud permisiva es ligeramente mayor en éstos últimos). Los mayores de 44, quedan clasificados en función de la ideología (en los tres grupos la actitud pronosticada es la restrictiva) diferenciando entre aquellos que son de izquierda, centro y derecha (presentados 
el mismo nodo) y los que no contestan sobre su ideología, los que mayor porcentaje de actitud restrictiva presentan (65,9\%).

- Confesión ortodoxa: es el tercer nodo más numeroso (más de 5.500 casos), y la categoría pronosticada es la actitud restrictiva hacia la inmigración (65\%). La mejor predictora de este grupo es la edad: el 61,4\% de los encuestados ortodoxos de entre 15-44 años mantienen una actitud restrictiva, llegando al $67,4 \%$ entre los mayores de 44 de la misma confesión (ambos son nodos terminales).

- Confesión judía: la categoría pronosticada de este segmento es la actitud restrictiva hacia la inmigración $(74,8 \%)$ y la principal variable predictora es la ideología, diferenciando entre aquellos que se declaran de izquierda (55,4\% de actitud restrictiva), los de centro (70,3\%) y los que no contestan sobre su ideología y los de derecha (81,9\%). Los de izquierda y centro son segmentados por la edad en el siguiente nivel, mostrando porcentajes más bajos de actitud restrictiva entre los más jóvenes que entre los mayores.

- Religiones orientales y otras no cristianas: es el nodo menos numeroso (343 casos) y su categoría pronosticada es la actitud permisiva hacia la inmigración $(66,5 \%)$-la más alta de todas las confesiones religiosas-. Este nodo sólo cuenta con una segmentación a partir de la edad: aquellos que tienen entre 15 y 44 años tienen una actitud permisiva más frecuente (72,3\%) que los mayores de 44 $(59,4 \%)$. 


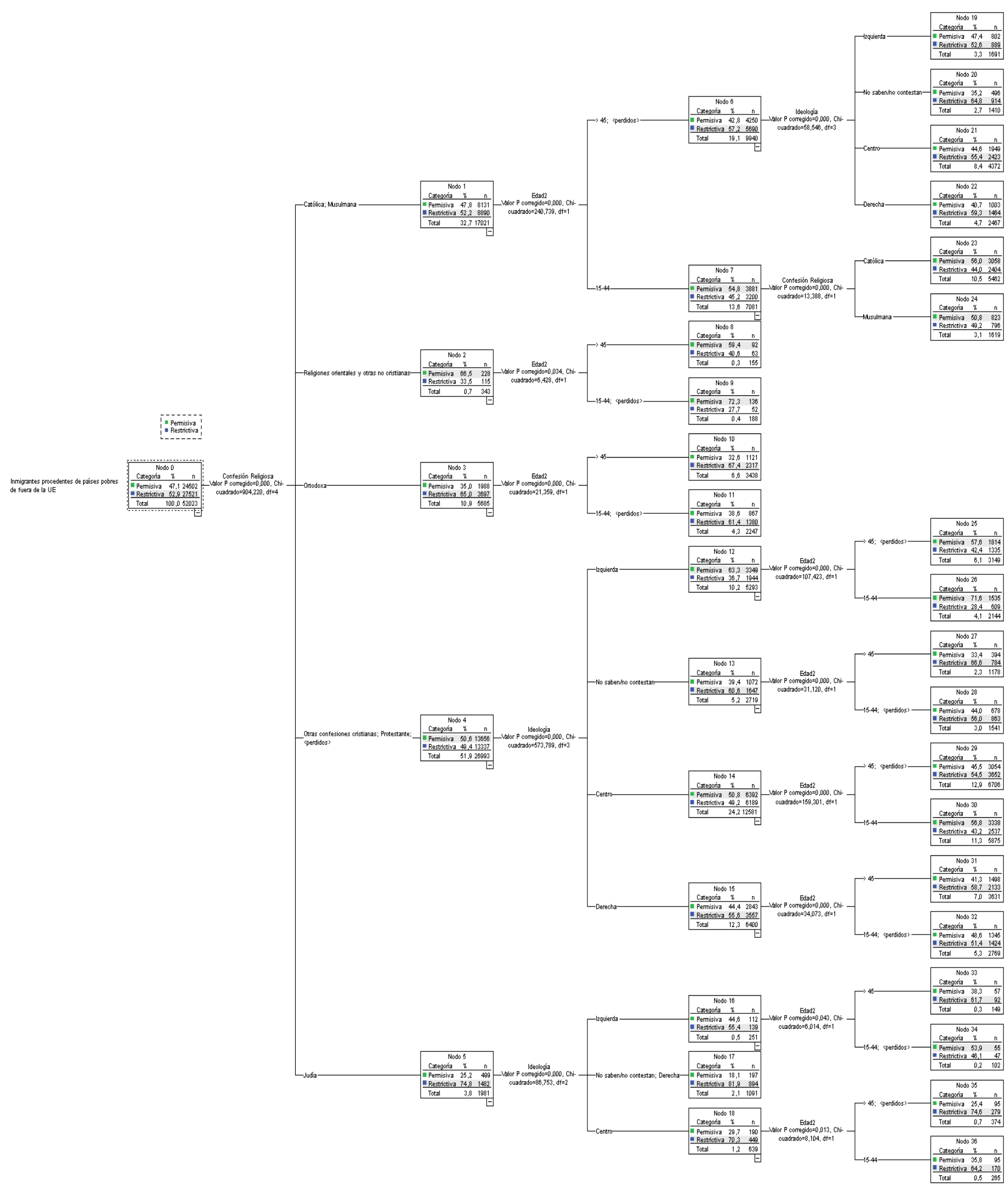




\section{ANÁLISIS POR PAÍSES DE EUROPA OCCIDENTAL:}

El análisis por países se ha realizado entre aquellos de Europa Occidental que participaron en la Encuesta Social Europea de 2012, contando con un total de quince países europeos.

A continuación se muestra la distribución de frecuencias (expresadas en porcentaje válido) de las variables dependientes de cada país, y posteriormente se muestran los resultados del análisis de correlación con determinadas variables contextuales de carácter macroeconómicas, migratorias y políticas.

\section{A. Actitudes y valoraciones de la inmigración en Europa Occidental:}

El análisis de la variable dependiente "Actitud hacia la inmigración procedente de países pobres de fuera de la UE" ${ }^{24}$ muestra diferencias muy significativas entre los países considerados (Gráfico 8). Fijándonos en la actitud restrictiva, se registra una diferencia de más de 50 puntos porcentuales entre el país con el porcentaje más bajo de actitud restrictiva -Suecia (16\%)- y el país con el más alto, Portugal $(68,6 \%)$.

Cinco países superan el $50 \%$ de actitud restrictiva hacia la inmigración de países pobres no comunitarios: Portugal $(68,6 \%)$, Finlandia $(62,7 \%)$, Reino Unido $(59,6 \%)$ y Dinamarca $(50,9 \%)$. Es interesante que Finlandia, Portugal y Dinamarca tengan porcentajes altos de actitud restrictiva hacia la inmigración, considerando que están entre los cinco países -de los considerados en el estudio- con menos porcentaje de población inmigrante $(3,1 \%, 4,2 \%, 6,2 \%$ respectivamente).

Por encima del porcentaje de actitud restrictiva de todos los países de la ESE2012 $(52,9 \%)$ se encuentran sólo Portugal, Finlandia y Reino Unido.

\footnotetext{
${ }^{24}$ Anexo 4.
} 


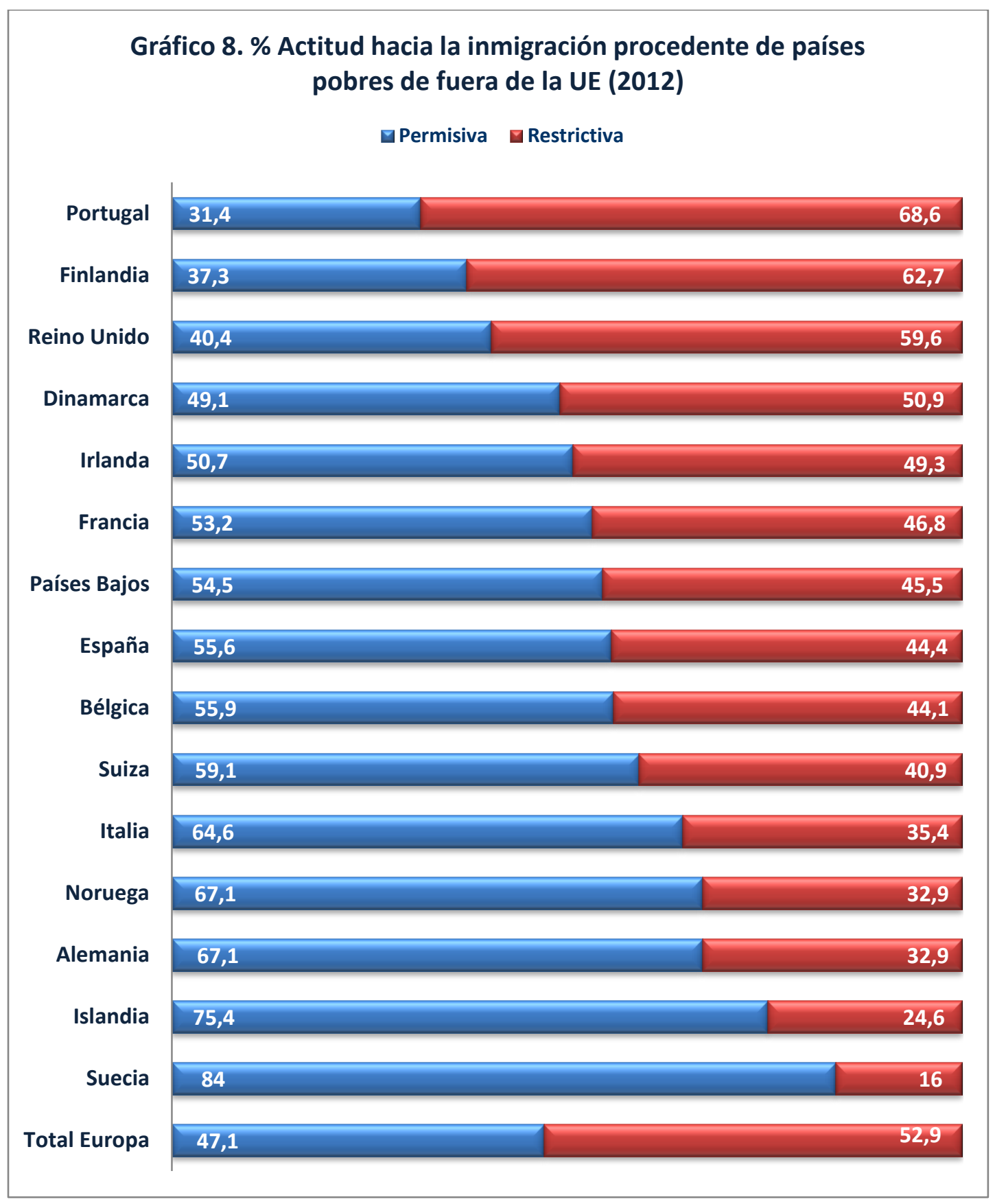

Fuente: elaboración propia a partir de la ESE 2002-2012

Los gráficos 9, 10 y 11 muestran la valoración media ${ }^{25}$ que cada país realiza del efecto de la inmigración en la economía, cultura y condiciones de vida del país. La valoración se mide en una escala que oscila entre cero y diez, donde cero es una valoración muy negativa, y diez, una muy positiva.

\footnotetext{
${ }^{25}$ Anexo 5.
} 
En las tres valoraciones que se realizan, Portugal, Reino Unido y Francia están por debajo de la media europea (4,87 en economía, 5,51 en cultura y 4,94 en condiciones de vida). Si consideramos que el valor central de la escala es 5,5, cuatro países darían una valoración negativa del efecto de la inmigración en los tres ámbitos: Portugal, Reino Unido, Francia e Irlanda.

Diez de los quince países valoran de forma negativa el efecto de la inmigración en la economía (de peor a mejor valoración): Portugal, Reino Unido, Bélgica, Francia, Irlanda, Dinamarca, Italia, España, Países Bajos y Finlandia. Los mismos países valoran de forma negativa el efecto de la inmigración en las condiciones de vida del país, con excepción de Finlandia, que le da un aprobado raspado $(5,61)$ y sumando a Alemania en este caso $(5,35)$. Por el contrario, la valoración del efecto de la inmigración en la cultura del país es mucho más positiva: sólo cuatro de los quince países analizados dan una valoración negativa (Reino Unido, Portugal, Francia e Irlanda).

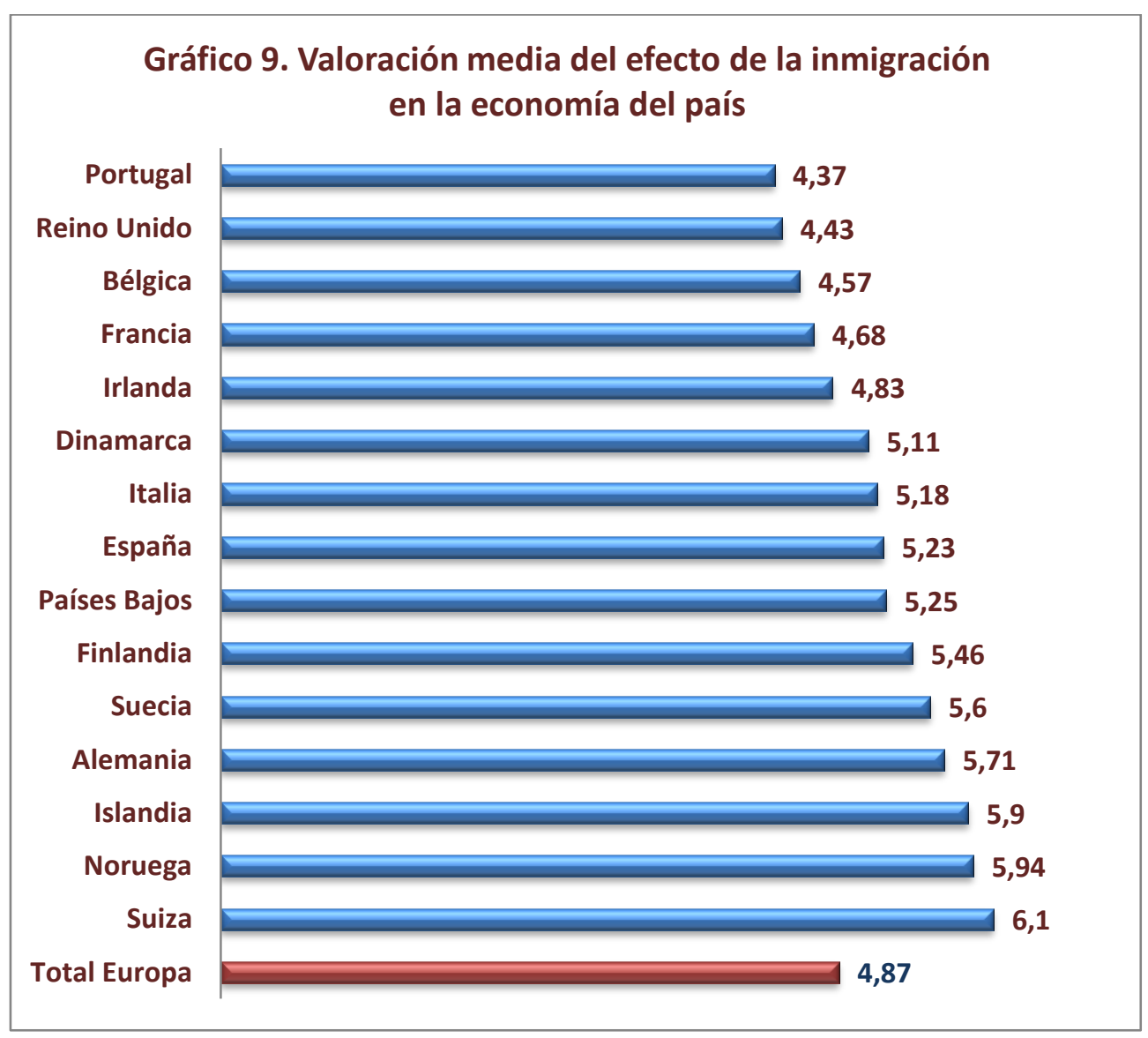

Fuente: elaboración propia a partir de la ESE 2012 


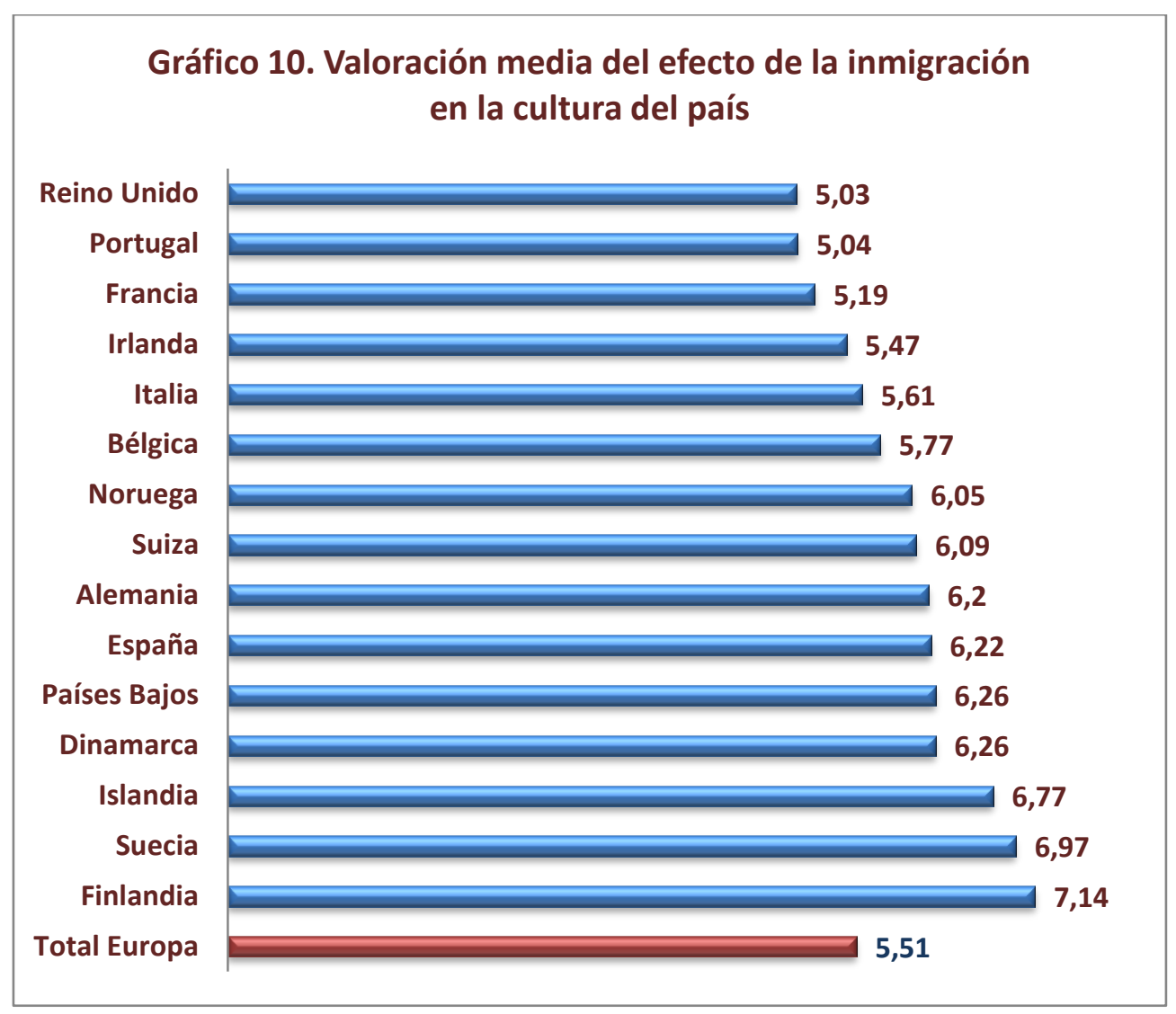

Fuente: elaboración propia a partir de la ESE 2012

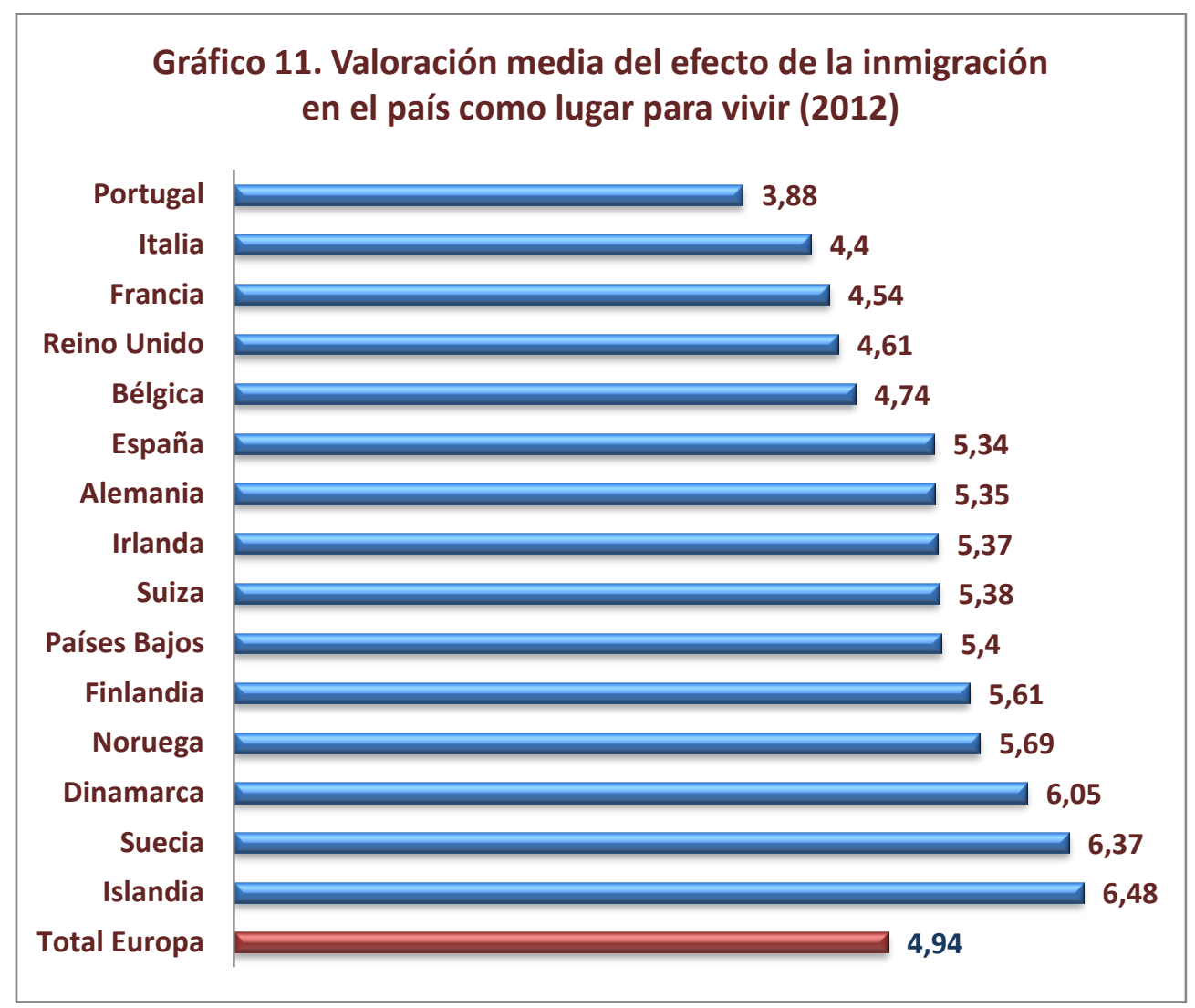

Fuente: elaboración propia a partir de la ESE 2012 


\section{B. Análisis del contexto socio-económico y político:}

Para analizar la posible relación del contexto socioeconómico y político del país en la actitud que se mantiene hacia la inmigración, se ha realizado una base de datos en el software estadístico SPSS con datos sobre inmigración (Tabla 2), indicadores macroeconómicos, de desigualdad y protección social (Tabla 3) y voto extremista a formaciones de extrema derecha (Tabla 4) para cada país analizado.

\begin{tabular}{|c|c|c|c|}
\hline & $\begin{array}{c}\% \text { No- } \\
\text { nacionales }\end{array}$ & $\begin{array}{l}\text { \% De países } \\
\text { miembros de la } \\
\text { UE }\end{array}$ & $\%$ No comunitarios \\
\hline Alemania & 8,8 & 3,2 & 5,6 \\
\hline Bélgica & 10,6 & 6,8 & 3,8 \\
\hline Dinamarca & 6,2 & 2,3 & 4 \\
\hline España & 12,3 & 5 & 7,2 \\
\hline Finlandia & 3,1 & 1,1 & 2 \\
\hline Francia & 5,9 & 2,1 & 3,8 \\
\hline Irlanda & 8,1 & 6,5 & 1,5 \\
\hline Islandia & 6,6 & 5,2 & 1,4 \\
\hline Italia & 7,5 & 2,2 & 5,3 \\
\hline Noruega & 7,5 & 4,4 & 3,1 \\
\hline Países Bajos & 4 & 2 & 2 \\
\hline Portugal & 4,2 & 1 & 3,2 \\
\hline Reino Unido & 7,2 & 3,3 & 3,9 \\
\hline Suecia & 6,6 & 2,9 & 3,7 \\
\hline Suiza & 22,4 & 13,9 & 8,5 \\
\hline
\end{tabular}

Los datos sobre inmigración (Tabla 2) indican que los cinco países con mayor porcentaje de población inmigrante son Suiza $(22,4 \%)$, España $(12,3 \%)$, Bélgica $(10,6 \%)$, Alemania $(8,8 \%)$ e Irlanda $(8,1 \%)$. Suiza, España y Alemania son también 
los tres países con mayor porcentaje de población inmigrante no comunitaria $(8,5 \%$, $7,2 \%$ y $5,6 \%$ respectivamente).

Sorprende que los países que cuentan con mayor porcentaje de población inmigrante, no sean los que mayor porcentaje de actitud restrictiva registran, ni los que peor valoración dan al efecto de la inmigración en la economía, cultura y condiciones de vida de sus países. Suiza, el país que mayor porcentaje de población extranjera tiene es el que mejor valoración media tiene del efecto de la inmigración en la economía de su país; supera la valoración media europea del efecto de la inmigración en cultura y condiciones de vida, y está por debajo de la media europea en actitud restrictiva hacia la inmigración.

En el lado opuesto, países como Portugal y Finlandia, que son los dos países que mayor porcentaje de actitud restrictiva registran (68,6 y 62,7\% respectivamente) son los que menor porcentaje de población inmigrante tienen, junto a los Países Bajos (3,1\% Finlandia, y 4,2\% Portugal).

\begin{tabular}{|c|c|c|c|c|c|c|c|c|}
\hline & $\begin{array}{c}\% \\
\text { Desempleo }\end{array}$ & $\begin{array}{c}\% \\
\text { Desempleo } \\
\text { larga } \\
\text { duración }\end{array}$ & $\begin{array}{c}\% \\
\text { Crecimiento } \\
\text { PIB anual }\end{array}$ & $\begin{array}{l}\text { PIB per } \\
\text { cápita }\end{array}$ & Indice GINI & $\begin{array}{l}\text { Gasto } \\
\text { protección } \\
\text { social } \\
\text { (\%PIB) }\end{array}$ & $\begin{array}{l}\text { Gasto } \\
\text { público en } \\
\text { educación } \\
\text { (\%PIB) }\end{array}$ & $\begin{array}{l}\text { Gasto } \\
\text { público en } \\
\text { sanidad } \\
\text { (\%PIB) }\end{array}$ \\
\hline Alemania & 5,4 & 45,2 & 0,7 & 42.598 & 28,3 & 30,7 & 5,1 & 11,3 \\
\hline Bélgica & 7,5 & 44,6 & $-0,1$ & 43.396 & 26,6 & 29,9 & 6,6 & 10,8 \\
\hline Dinamarca & 7,5 & 28 & $-0,4$ & 56.364 & 28,1 & 33,3 & 8,7 & 11,2 \\
\hline España & 25,2 & 44,5 & $-1,6$ & 28.282 & 35 & 25,7 & 5 & 9,6 \\
\hline Finlandia & 7,6 & 21,4 & -1 & 45.649 & 25,9 & 30,6 & 6,8 & 9,1 \\
\hline Francia & 9,9 & 39,9 & 0 & 39.759 & 30,5 & 33,8 & 5,9 & 11,7 \\
\hline Irlanda & 14,7 & 61,2 & 0,2 & 45.922 & 29,9 & 29,6 & 6,4 & 8,1 \\
\hline Islandia & 6 & 25,4 & 1,5 & 42.362 & 24 & 24,5 & 7,6 & 9,1 \\
\hline Italia & 10,7 & 52,4 & $-2,4$ & 33.814 & 31,9 & 29,9 & 4,5 & 9,2 \\
\hline Noruega & 3,2 & 8,1 & 2,9 & 99.636 & 22,6 & 25,6 & 6,9 & 9 \\
\hline P. Bajos & 5,3 & 33,1 & $-1,2$ & 45.961 & 25,4 & 32,1 & 6 & 12,4 \\
\hline Portugal & 15,6 & 48,7 & $-3,2$ & 20.175 & 34,5 & 27 & 5,6 & 9,4 \\
\hline R. Unido & 7,9 & 34,7 & 0,3 & 38.649 & 32,8 & 28 & 6,2 & 9,4 \\
\hline Suecia & 8 & 15,9 & 0,9 & 55.039 & 24,8 & 30,4 & 7 & 9,6 \\
\hline Suiza & 4,2 & 34,7 & 1 & 78.929 & 28,8 & 26,6 & 5,2 & 11,3 \\
\hline
\end{tabular}


La tabla 3 muestra importantes diferencias entre los países europeos considerados en cuanto a desempleo, desigualdad, riqueza y políticas sociales. Con algunas excepciones, España, Portugal, Italia e Irlanda encabezan las listas de desempleo, desigualdad de ingresos, menos renta per cápita, y menos gasto público en políticas sociales. En el otro extremo, se encuentran los países del norte de Europa que cuentan con bajos porcentajes de desempleo, índices bajos de desigualdad de la riqueza, las rentas per cápita más altas, y mayores porcentajes del PIB dedicados a las políticas de bienestar, como la sanidad, educación y protección social.

\section{Tabla 4. \% Voto a principal partido de extrema derecha}

\begin{tabular}{llllc} 
País & Órgano electo & Año & Partido Político & \% votos válidos \\
Alemania & Parlamento Federal & 2013 & National Democratic Party of Germany (NPD) & 1,5 \\
Bélgica & Cámara Representantes & 2010 & Flemish Interest (VB) & 7,5 \\
Dinamarca & Parlamento & 2011 & Danish People's Party (DF) & 12,3 \\
España & Congreso de los Diputados & 2011 & España 2000 (E2000) & 0,04 \\
Finlandia & Parlamento & 2011 & True Finns (PS) & 19,1 \\
Francia & Asamblea Nacional & 2012 & National Front (FN) & 13,6 \\
Irlanda & & & & 0 \\
Islandia & & & & 0 \\
Italia & Cámara de los Diputados & 2013 & Forza Nuova (FN) & 0,26 \\
Noruega & Gran Asamblea & 2013 & Progress Party (FrP) & 16,3 \\
P. Bajos & Parlamento & 2012 & Party for Freedom (PV) & 10,1 \\
Portugal & Asamblea de la República & 2011 & Partido Nacional Renovador (PNR) & 0,3 \\
R.U. & Cámara de los Comunes & 2010 & United Kingdom Independence Party (UKIP) & 3,1 \\
Suecia & Asamblea Legislativa & 2010 & Sweden Democrats (SD) & 5,7 \\
Suiza & Consejo Nacional & 2011 & Swiss People's Party (SVP) & 26,6 \\
\hline & Fuente: elaboración propia &
\end{tabular}

${ }^{26}$ EI SVP puede ser considerado una formación populista de derecha, pero su discurso anti-inmigración es tan potente y demagogo como el del Frente Nacional y otras formaciones de extrema derecha) 
La tabla 4 muestra el porcentaje de votos válidos obtenido por las principales formaciones de extrema derecha de los países europeos considerados para el análisis. Los datos se han obtenido de la página web www.recursoselectorales.org que ofrece información electoral de países de todo el mundo. Se ha escogido el partido más votado en el caso de que hubiera dos o más partido ubicados en este lado del espectro ideológico en un mismo país. Los resultados se corresponden a los obtenidos en las elecciones legislativas (de la cámara baja, en caso de parlamentos bicamerales) celebradas entre 2010 y 2013 (se ha escogido para cada caso, la fecha más cercana a la realización de la ESE2012).

Los países que registraron porcentajes más altos de voto extremista de derecha fueron, de mayor a menor: Suiza, Finlandia, Noruega, Francia, Dinamarca, Países Bajos y Bélgica. Les sigue Suecia, Reino Unido y Alemania. El resto de países, Portugal, Italia, España, Irlanda e Islandia, cuentan con unas formaciones extremistas con resultados electorales por debajo del $1 \%$.

Observando los datos se puede apreciar que el mapa del extremismo (parlamentario) sólo se corresponde parcialmente con el mapa del rechazo hacia la inmigración. De los cuatro países que superaron el 50\% de actitud restrictiva hacia la inmigración en la ESE2012, sólo dos cuentan con partidos de extrema derecha consolidados electoralmente (Finlandia y Dinamarca). Francia y Bélgica, que cuentan con formaciones de extrema derecha sólidas y con trayectoria histórica, mostraron unos porcentajes de actitud restrictiva hacia la inmigración relativamente altos (en torno al 44-46\%) y valoraciones negativas del impacto de la inmigración en la economía y en las condiciones de vida del país.

Por su parte, los países que se mostraron más permisivos hacia la inmigración en la ESE2012, (Suecia, Islandia y Alemania), son también los que contaban con formaciones de extrema derecha con escaso o nulo éxito electoral (algo más alto en el caso de Suecia).

No obstante, se dan importantes excepciones que impiden hablar de una correspondencia entre extremismo político (de derecha) y rechazo hacia la inmigración. Portugal, el país que mayor rechazo mostró en la ESE2012 (68,6\%), carece de partidos de extrema derecha fuertes en términos electorales. El Partido Nacional Renovador, perteneciente al Frente Nacional Europeo, no alcanzó el 1\% en 
las últimas elecciones legislativas. Del mismo modo, Irlanda que mostró un alto porcentaje de rechazo hacia la inmigración en la ESE2012 (49,3\%) y valoraciones negativas del efecto de la inmigración en el país, no cuenta tampoco con formaciones de extrema derecha electoralmente sólidas. Por lo que respecta al Reino Unido (tercer país con el porcentaje más alto de rechazo hacia la inmigración), los éxitos electorales del United Kingdom Independence Party son más recientes (en las últimas elecciones europeas obtuvieron el $26,7 \%$ de los votos ${ }^{27}$, y un $25 \%$ en los municipios en los que se presentaba en las municipales de 2013, y queda por ver si se consolidan en el tiempo y en las elecciones legislativas. El British National Party, por su parte, es una formación política extremista que está en decadencia y que no supera el $1-2 \%$ de los votos en las elecciones legislativas.

Dentro de los países más permisivos, Noruega (el cuarto con el porcentaje más alto de actitud permisiva) vio como la formación extremista Progress Party obtenía un 16,3\% de los votos en la Gran Asamblea en 2013, pasando a formar un gobierno de coalición con los conservadores ${ }^{28}$

El análisis de correlación lineal (Tabla 5) de estas variables contextuales respecto a las variables dependientes -valoración del efecto de la inmigración en la economía, cultura y condiciones de vida del país-, ha mostrado que el contexto guarda cierta correlación con la valoración que se hace de la inmigración.

\footnotetext{
${ }^{27}$ www.recursoselectorales.org
}

${ }^{28}$ La extrema derecha xenófoba entra en el gobierno de Noruega por primera vez (2013, 1 de octubre) RTVE.es 


\begin{tabular}{lccc}
\hline $\begin{array}{l}\text { Tabla 5. Resultados del análisis de correlación de Pearson: Valoración del efecto de } \\
\text { la inmigración en el país receptos/Variables socioeconómicas y migratorias }\end{array}$ \\
\hline & Economía & Cultura & Lugar para vivir \\
\hline \% No-nacionales & 0,369 & $-0,035$ & 0,028 \\
\hline$\%$ De países miembros de la UE & 0,385 & 0,013 & 0,157 \\
\hline$\%$ No comunitarios & 0,228 & $-0,097$ & $-0,187$ \\
\hline$\%$ Desempleo & $-0,435$ & $-0,26$ & $-0,315$ \\
\hline \% Desempleo larga duración & $-0,549^{*}$ & $-0,609^{*}$ & $-0,628^{*}$ \\
\hline \% Crecimiento PIB anual & $0,572^{*}$ & 0,289 & $0,606^{*}$ \\
\hline PIB per cápita & $0,641^{* *}$ & 0,286 & 0,473 \\
\hline Indice GINI & $-0,607^{*}$ & $-0,655^{* *}$ & $-0,704^{* *}$ \\
\hline \% del PIB en Gasto protección social & $-0,324$ & $-0,039$ & $-0,092$ \\
\hline \% del PIB Gasto público en educación & 0,068 & $-0,383$ & $0,623^{*}$ \\
\hline \% del PIB Gasto público en sanidad & 0,034 & $-0,002$ & $-0,057$ \\
\hline \% Voto Extrema Derecha & 0,399 & 0,260 & 0,183 \\
\hline
\end{tabular}

Fuente: elaboración propia

*La correlación es significativa en el nivel 0,05

**La correlación es significativa en el nivel 0,01

El porcentaje de desempleo de larga duración y el Índice Gini han mostrado tener una correlación estadísticamente significativa con la valoración del efecto de la inmigración en los tres ámbitos (economía, cultura y lugar para vivir). La correlación es intensa y negativa, de forma que cuanto mayor es el porcentaje de desempleo de larga duración y el índice de desigualdad de ingresos, peor es la valoración que se realiza del efecto de la inmigración en los tres ámbitos (los valores bajos de la valoración se corresponden con una valoración negativa). Por ámbitos:

- La valoración que se realiza del efecto de la inmigración en la economía se correlaciona de forma significativa y negativa con el desempleo a larga duración y el Índice Gini, y de forma positiva con el crecimiento del PIB y la renta per cápita.

- La valoración del efecto de la inmigración en la cultura guarda una correlación estadísticamente significativa y negativa con el desempleo a larga duración y el Índice Gini. 
- La valoración del efecto de la inmigración en las condiciones de vida del país, se correlaciona de forma significativa y negativa con el desempleo a larga duración, el Índice Gini, y de forma positiva con el crecimiento del PIB y el gasto público en educación.

De forma que, a mayor porcentaje de desempleo de larga duración, mayor desigualdad en la riqueza, menor crecimiento del PIB, menos renta per cápita y gasto público en educación, peor es la valoración del efecto del efecto de la inmigración en los ámbitos citados.

Destaca el hecho de que el porcentaje de población inmigrante, ya sea comunitaria o no comunitaria, muestre unos valores de correlación lineal prácticamente nulos. Sí se identifican unos valores de correlación algo mayores (entre 0,2 y 0,38 ) en la valoración del efecto de la inmigración en la economía. El signo de la correlación es positivo, lo que indicaría que a mayor porcentaje de población inmigrante, mejor valoración del efecto de la inmigración en la economía, si bien el nivel de significación es mayor de 0,05 , por lo que no se acepta como estadísticamente significativo. Se puede afirmar entonces que la tasa de población inmigrante no guarda una correlación estadísticamente significativa con la valoración que se realiza del impacto de la inmigración en el país receptor.

Por último, el análisis ha mostrado que no existe una correlación lineal estadísticamente significativa entre la valoración del efecto de la inmigración y el voto extremista de derecha. Los valores de la correlación son muy bajos en el caso de la valoración del impacto de la inmigración en la cultura del país $(0,260)$ y en las condiciones de vida $(0,183)$, y algo mayor en la valoración que se hace de la economía $(0,399)$. El signo de la correlación es además positivo, indicando que los países con porcentajes más altos de voto extremista de derecha se corresponden con los que valoran mejor el efecto de la inmigración en la economía. La dirección de esta correlación tiene cierto sentido si se tiene en cuenta que los países con partidos de extrema derecha consolidados electoralmente coinciden con aquellos países que gozan de mejores condiciones socio-económicas en términos generales, como es el caso de Suiza, Finlandia, Noruega, Países Bajos y Dinamarca.

La Tabla 6 muestra los resultados del análisis de correlación de Pearson realizado entre el voto extremista de derecha y las variables socioeconómicas y migratorias. El 
análisis muestra que el porcentaje de desempleo y el PIB per cápita guardan una correlación estadísticamente significativa con el porcentaje de voto a partidos de extrema derecha. Esta correlación es negativa en el caso del desempleo: los países con menores tasas de paro son los que tienen porcentajes más alto de voto extremista de derecha; y, positiva en el caso del PIB per cápita: a mayor renta per cápita, mayor voto extremista de derecha (esta variable es la que obtiene la correlación más alta). El desempleo de larga duración y el Índice Gini, si bien no han pasado la prueba de significación, muestran valores de correlación relativamente altos: a menor porcentaje de desempleo de larga duración y menor desigualdad de ingresos, mayor porcentaje de voto extremista.

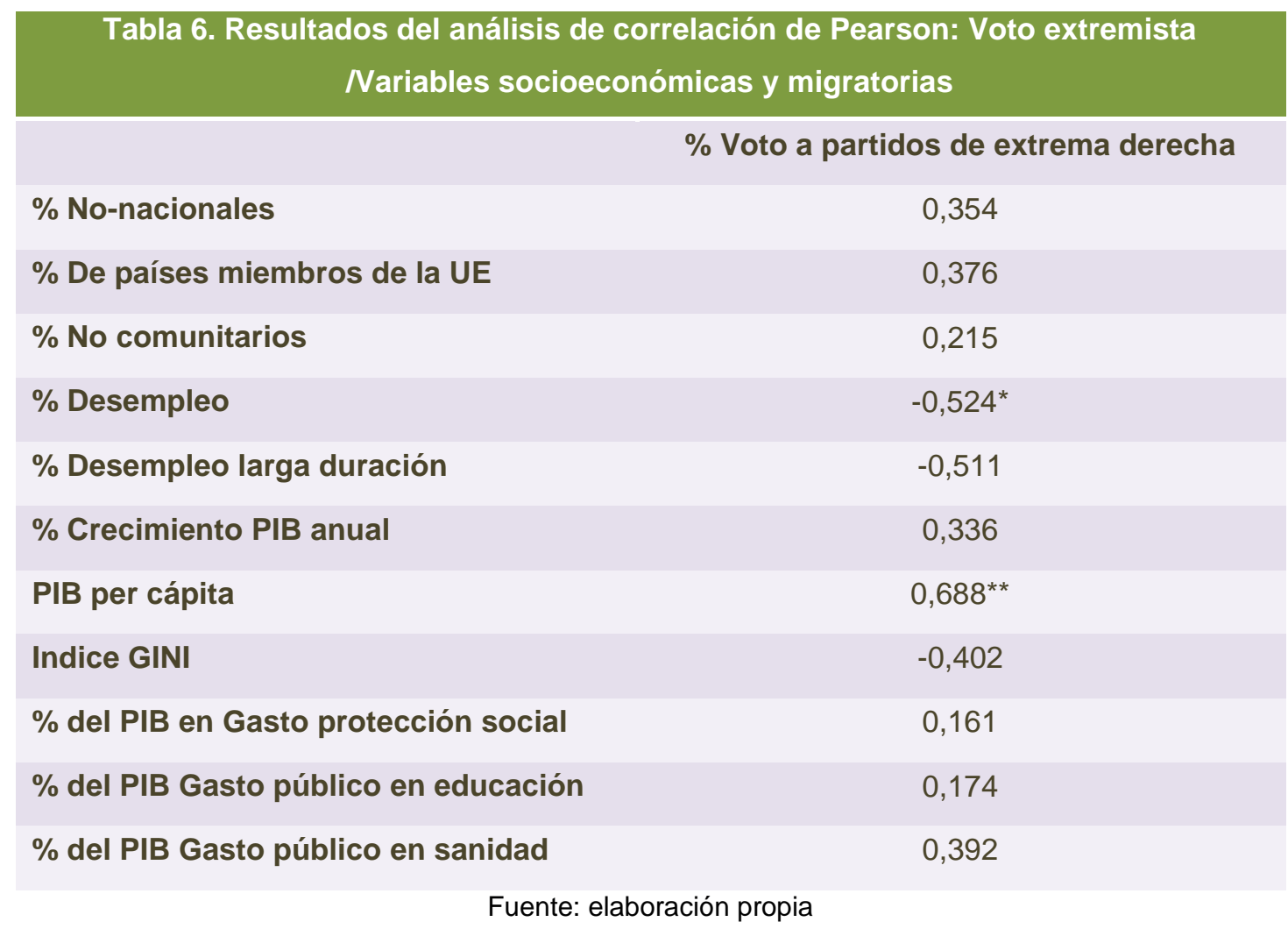

*La correlación es significativa en el nivel 0,05

**La correlación es significativa en el nivel 0,01

Los análisis de correlación permiten afirmar que el voto extremista y la valoración del impacto de la inmigración no se encuentran correlacionados de forma significativa. La valoración de la inmigración es más negativa en aquellos países con altas tasas 
de desempleo, con mayor desigualdad de ingresos y con menos renta per cápita, mientras que la correlación del voto extremista con estas variables es la inversa. En ninguno de los casos, la tasa de población inmigrante mantiene una correlación estadísticamente significativa, por lo que no se podría afirmar que a mayor población inmigrante peor valoración de ésta o mayor voto extremista.

En la medida en que el análisis de correlación ha mostrado que los países con porcentajes más altos de votos a formaciones de extrema derecha no son necesariamente los que peores valoran la inmigración ni los que cuentan con las actitudes más restrictivas hacia ésta, y viceversa, se ha procedido al análisis por tablas de contingencia ${ }^{29}$ del voto a partidos en las últimas elecciones nacionales y la actitud hacia la inmigración (ESE2012).

Para el análisis, se han descartado los partidos que representan un porcentaje válido inferior al 1\%. El resumen de los resultados de las tablas de contingencia se muestra en la Tabla 7, y recoge aquellos partidos que se han podido ubicar en la escala ideológica izquierda-derecha. Para la ubicación ideológica se ha consultado la página web de Manifiesto Project, elaborado por la Universidad de Berlín, que cubre los programas electorales de más de 50 países de las elecciones celebradas desde 1945 hasta la actualidad, otorgándoles a los partidos políticos una puntuación en función de su ubicación en la escala ideológica (-100 corresponde a la máxima puntuación de izquierda y +100 a la derecha). No obstante, también se ha utilizado literatura sobre el tema (Simón, 2007 y Martínez y Mella, 2012) para los casos más dudosos, así como el recurso a su afiliación internacional (especialmente a los grupos políticos del Parlamento Europeo).

La Tabla 7 muestra un total de 119 partidos políticos, de los cuales 52 se han clasificado como de izquierda y centro izquierda, 20 como partidos de centro, 37 de centro derecha y derecha, y 10 como partidos de extrema derecha.

En todos los países, con excepción de Portugal, el voto a partidos muestra una relación estadísticamente significativa (para un nivel de significación de 0,01) con la

\footnotetext{
${ }^{29}$ Anexo 6.
} 
variable dependiente: "Actitud hacia la inmigración procedente de países pobres de fuera de la UE". Islandia, muestra un nivel de significación observado de 0,042, por lo que sólo su relación con la variable dependiente sólo se puede aceptar como estadísticamente significativa en el nivel 0,05.

Por su parte, la diferencia de porcentajes señalan que:

- Los encuestados que votaron a la izquierda/centro-izquierda, son los que registran frecuencias de actitud restrictiva más bajas: sólo el $13,46 \%$ de los partidos de esta categoría tienen porcentajes de actitudes restrictivas por encima del $50 \%$

- Los encuestados que votaron al centro muestran frecuencias de actitud restrictiva más altas que los de izquierda/centro-izquierda y más bajas que los de centro-derecha/derecha: un $25 \%$ de los partidos clasificados como de centro registraron porcentajes de actitud restrictiva por encima del $50 \%$

- Los encuestados que votaron al centro-derecha/derecha muestran frecuencias de actitud restrictiva más alta que los dos grupos de partidos anteriores: un 48,7\% de los partidos clasificados en esta categoría registraron porcentajes de actitud restrictiva por encima del $50 \%$

- Finalmente, los encuestados que votaron a partidos de extrema derecha son los que mayor frecuencia de actitud restrictiva registran: todos superan el $50 \%$ de actitud restrictiva, y cinco de ellos, superan el $80 \%$.

Se puede afirmar entonces que, si bien la actitud restrictiva hacia la inmigración es mucho más frecuente dentro de los votantes de extrema derecha, y derecha, el rechazo hacia la inmigración no es exclusivo de éstos. Algunos votantes de izquierda y centro han mostrado porcentajes altos de rechazo hacia la entrada de inmigración procedente de países pobres de fuera de la Unión Europea. Asimismo, no todos los votantes de extrema derecha y derecha registran porcentajes altos de actitud restrictiva hacia la inmigración.

Por lo que refiere a la izquierda, los votantes de la formación francesa Lucha Obrera, partido de extrema izquierda, han mostrado una actitud restrictiva hacia la inmigración del 76,9\%. Un porcentaje similar de rechazo registran los votantes de la 
coalición formada por el Partido Comunista Portugués y el Partido Ecologista, CDU (72,2\%). El Partido Socialdemócrata Finés registra un 65,1\% de actitud restrictiva hacia la inmigración. La centro-izquierda británica muestra, por su parte, porcentajes cercanos al $60 \%$ de rechazo en los votantes laboristas y nacionalistas escoceses.

Los centristas finlandeses (Kesk) registran una actitud restrictiva hacia la entrada de inmigración del $73,2 \%$, porcentaje similar al de los votantes del Partido Socialista de Portugal, ubicado en el centro ideológico (69,3\%).

Dentro de la extrema derecha, los Demócratas Suecos y el FrP noruego no han mostrado porcentajes excesivamente altos de rechazo hacia la inmigración (53,1\% y $57,3 \%$ respectivamente). Por último, los partidos de derecha alemanes e islandeses han mostrado porcentajes de actitud restrictiva por debajo del $40 \%$, mientras que los partidos suecos de derecha no alcanzan el $20 \%$.

Tabla 7. Resumen tablas de contingencia: Actitud hacia la inmigración/voto a partidos por países

\begin{tabular}{|c|c|c|c|c|c|c|c|}
\hline \multicolumn{2}{|c|}{ Izquierda-centro izq. } & \multicolumn{2}{|c|}{ Centro } & \multicolumn{2}{|c|}{ Derecha-centro dcha. } & \multicolumn{2}{|c|}{ Ext. Derecha } \\
\hline Partido & $\begin{array}{c}\% \text { Act. } \\
\text { restrictiva }\end{array}$ & Partido & $\begin{array}{c}\% \text { Act. } \\
\text { restrictiva }\end{array}$ & Partido & $\begin{array}{c}\% \text { Act. } \\
\text { restrictiva }\end{array}$ & Partido & $\begin{array}{c}\% \text { Act. } \\
\text { restrictiva }\end{array}$ \\
\hline \multicolumn{8}{|c|}{ ALEMANIA } \\
\hline SPD & 27,2 & & & $\mathrm{CDU} / \mathrm{CSU}$ & 36 & NPD & 91,7 \\
\hline GRÜNE & 12,6 & & & FDP & 38,6 & & \\
\hline Die Linke & 39,7 & & & & & & \\
\hline PIRATEN & 45,5 & & & & & & \\
\hline \multicolumn{8}{|c|}{ BÉLGICA } \\
\hline SP.A & 33,6 & Green! & 17,5 & $\mathrm{CD} \& \mathrm{~V}$ & 42,3 & VB & 68,1 \\
\hline Ecolo & 27,5 & $\mathrm{CDH}$ & 40,3 & $\mathrm{~N}-\mathrm{VA}$ & 52,1 & $\mathrm{FN}$ & 87,5 \\
\hline PS & 49,8 & $\mathrm{MR}$ & 57,4 & Open VLD & 47,7 & & \\
\hline \multicolumn{8}{|c|}{ DINAMARCA } \\
\hline$S$ & 46 & RV & 35,3 & $\mathrm{KF}$ & 51,7 & $\mathrm{DF}$ & 83,3 \\
\hline SF & 30,2 & & & $\begin{array}{l}\text { Cristianos- } \\
\text { demócratas }\end{array}$ & 46,2 & & \\
\hline \multirow[t]{2}{*}{$\begin{array}{l}\text { Alianza roji- } \\
\text { verde }\end{array}$} & 20,2 & & & $\begin{array}{l}\text { Alianza } \\
\text { liberal }\end{array}$ & 64,9 & & \\
\hline & & & & V & 69 & & \\
\hline \multicolumn{8}{|c|}{ ESPAÑA } \\
\hline PSOE & 43,3 & & & PP & 53,6 & & \\
\hline
\end{tabular}




\begin{tabular}{|c|c|c|c|c|c|c|c|}
\hline IU & 20 & & & $\mathrm{CiU}$ & 38,8 & & \\
\hline UPyD & 33,3 & & & PNV & 57,1 & & \\
\hline ERC & 38,9 & & & & & & \\
\hline EQUO & 21,4 & & & & & & \\
\hline \multicolumn{8}{|c|}{ FINLANDIA } \\
\hline SFP & 32,1 & KESK & 73,2 & KOK & 65,5 & PS & 80,1 \\
\hline VHR & 33,3 & $K D$ & 51,4 & & & & \\
\hline SDP & 65,1 & & & & & & \\
\hline VAS & 53 & & & & & & \\
\hline \multicolumn{8}{|c|}{ FRANCIA } \\
\hline NPA & 20 & MODEM & 35,7 & NC & 64,3 & $\mathrm{FN}$ & 76,2 \\
\hline LO & 76,9 & & & MPF & 58,8 & & \\
\hline FDG & 26,2 & & & UMP & 58,9 & & \\
\hline PRG & 55 & & & & & & \\
\hline PS & 37 & & & & & & \\
\hline EELV & 20,8 & & & & & & \\
\hline $\begin{array}{l}\text { Otros mov. } \\
\text { Ecologistas }\end{array}$ & 38,5 & & & & & & \\
\hline \multicolumn{8}{|c|}{ IRLANDA } \\
\hline GP & 40,5 & & & $\mathrm{FF}$ & 57,7 & & \\
\hline Lab & 43,2 & & & $\mathrm{FG}$ & 54 & & \\
\hline SF & 48,9 & & & & & & \\
\hline \multicolumn{8}{|c|}{ ISLANDIA } \\
\hline AS & 21,4 & PP & 30 & $\mathrm{PI}$ & 37,8 & & \\
\hline IV & 21,2 & & & $\mathrm{PL}$ & 25 & & \\
\hline \multicolumn{8}{|c|}{ ITALIA } \\
\hline PD & 22,1 & Con Monti & 11,1 & UDC & 55,6 & & \\
\hline SEL & 12,5 & & & $\mathrm{PdL}$ & 50,6 & & \\
\hline $\mathrm{RC}$ & 15,4 & & & LN & 42,9 & & \\
\hline M5S & 15,4 & & & FARE & 0 & & \\
\hline \multicolumn{8}{|c|}{ NORUEGA } \\
\hline SV & 8,7 & $\mathrm{Sp}$ & 36,7 & $\mathrm{KrF}$ & 10 & $\mathrm{FrP}$ & 57,3 \\
\hline A/ap & 28,3 & & & $\mathrm{H}$ & 41,8 & & \\
\hline v & 19 & & & & & & \\
\hline \multicolumn{8}{|c|}{ PAÍSES BAJOS } \\
\hline PvdA & 32,7 & & & VVD & 51,7 & PVV & 84,4 \\
\hline SP & 34,5 & D66 & 29,6 & CDA & 50 & & \\
\hline Izq-Verde & 26,3 & Part. de los & 40,7 & $\mathrm{CU}$ & 45 & & \\
\hline
\end{tabular}




\begin{tabular}{|c|c|c|c|c|c|c|c|}
\hline & & animales & & & & & \\
\hline & & & & SGP & 47,1 & & \\
\hline \multicolumn{8}{|c|}{ PORTUGAL } \\
\hline $\mathrm{BE}$ & 55,6 & PS & 69,3 & CDS-PP & 62,5 & & \\
\hline CDU & 72,2 & & & PSD & 67,5 & & \\
\hline \multicolumn{8}{|c|}{ REINO UNIDO } \\
\hline Lab & 59,4 & LDP & 50,6 & Cons & 69,1 & & \\
\hline SNP & 56,8 & & & & & & \\
\hline GP & 50 & & & & & & \\
\hline \multicolumn{8}{|c|}{ SUECIA } \\
\hline $\mathrm{MP}$ & 9,4 & $\mathrm{C}$ & 11,1 & KD & 6,4 & SD & 53,1 \\
\hline $\mathrm{S}$ & 14,2 & FP & 7,8 & $\mathrm{M}$ & 18 & & \\
\hline V & 8 & & & & & & \\
\hline \multicolumn{8}{|c|}{ SUIZA } \\
\hline SP & 22,7 & PLR & 41,5 & $\mathrm{BDP}$ & 42,5 & SVP & 75,4 \\
\hline \multirow[t]{3}{*}{ PES } & 20,3 & GLP & 31,9 & UDF & 50 & & \\
\hline & & EVP & 28,6 & & & & \\
\hline & & PDC & 46 & & & & \\
\hline
\end{tabular}

Fuente: elaboración propia a partir de la ESE 2012 


\section{CONCLUSIONES:}

\section{A. CONTRASTE DE HIPÓTESIS:}

Esta investigación tenía como como objetivo general estudiar las actitudes hacia la inmigración en Europa, con el objetivo último de dar con las variables tanto individuales como contextuales que inciden en la actitud de rechazo hacia la población inmigrante.

En primer lugar, el análisis univariante ha mostrado que la población receptora es más permisiva hacia la inmigración si ésta comparte el origen étnico/racial de la mayoría, menos permisiva si mantienen un origen étnico/racial diferente, y mayoritariamente restrictiva si la población inmigrante procede de países pobres de fuera de la Unión Europea. Esta última categoría de inmigrante es la menos deseable en términos sociales (Martín, Molina y Meardi, 2013), ya que reúne la condición de "pobres" además de la diferencia étnico/racial y cultural. Esta menor deseabilidad social se ha podido corroborar en el análisis de frecuencias de la Encuesta Social Europea de 2012, y en su evolución desde 2002. En todas las encuestas realizadas, la permisividad hacia la inmigración ha sido bastante mayor en el caso de que la población inmigrante comparta los rasgos étnico/raciales con la mayoría de la sociedad receptora. Por el contrario, la actitud es mayoritariamente restrictiva hacia la entrada de población inmigrante pobre y diferente en términos étnico/raciales.

En cuanto a su evolución, la actitud restrictiva hacia la entrada de población inmigrante procedente de países pobres ha sufrido una tendencia creciente desde 2002 hasta 2010, reduciéndose ligeramente en 2012. La evolución de la actitud hacia la entrada de población inmigrante de diferente origen étnico/racial ha sido más bien estable, mientras que el rechazo hacia la entrada de población de la misma raza o etnia que la mayoría ha seguido una tendencia decreciente alcanzando su mínimo en 2012. 
Por lo que respecta a la valoración media del impacto de la inmigración en el país receptor, ésta es negativa en el ámbito económico y en las condiciones de vida del país, mientras que es positiva (aunque con una puntuación muy baja) en el ámbito cultural. En la evolución de la Encuesta Social Europea, desde 2002 hasta 2010, el efecto de la inmigración en la economía y en las condiciones de vida del país ha sido valorado de forma más negativa que el impacto de la inmigración en la cultura del país. Las valoraciones se han ido polarizando a lo largo de los diez años que cubren la Encuesta Social Europea.

La primera hipótesis se confirma en parte: el rechazo hacia la inmigración se ha extendido en los últimos años por Europa. Eso sí, su extensión ha sido moderada y con un ligero descenso en 2012. Depende también del origen étnico/racial de la población inmigrante y su procedencia, crece el rechazo hacia la población inmigrante considerada "pobre" y extra-comunitaria (conlleva la diferencia étnico/racial y/o cultural). Asimismo, en los últimos años (a excepción de 2012) la valoración negativa del efecto de la inmigración ha crecido y se ha polarizado en cierto modo.

El análisis bivariante y multivariante permiten confirmar la segunda hipótesis: la actitud hacia la entrada de población inmigrante depende en buena medida del perfil socio-económico, pero tienen tanta o más incidencia el perfil ideológico y cultural de la persona, así como la valoración y actitud que se tenga ante la actualidad políticoeconómica y social.

Desde el punto de vista socioeconómico, el rechazo de la inmigración es más frecuente entre las personas con un nivel educativo bajo, escasos ingresos, de clase social baja o media-baja, inactivos desde el punto de vista laboral -con excepción de los estudiantes- y entre trabajadores con ocupaciones que requieren baja cualificación y/o de carácter manual.

Desde el punto de vista ideológico, las personas de extrema derecha y que no contestan sobre su ideología son las más reacias hacia la recepción de población inmigrante, seguidos de quienes se declaran de derecha. En el análisis por países, se ha constatado que los encuestados que votan a la extrema derecha muestran los 
porcentajes más altos de actitud restrictiva hacia la inmigración, mientras que los de izquierda son los que registran porcentajes los más bajos. No obstante, el rechazo hacia la inmigración no es exclusivo de la extrema derecha: también se registran porcentajes altos entre los votantes de centro-derecha, y algunos casos en el centro e izquierda.

Desde el punto de vista confesional, las personas que profesan el judaísmo, y la religión ortodoxa, son las que mayor rechazo hacia la inmigración registran, seguidas de musulmanes y católicos. El rechazo hacia la inmigración coincide también con un mayor conservadurismo en lo referente a las personas de orientación homosexual, y entre aquellos que no conceden importancia a la protección de los derechos de las minorías.

Por otra parte, los que valoran de forma negativa la situación económica, la labor del gobierno de su nación, la integración europea y el funcionamiento de la democracia en su país, son también los que más reacios se muestran ante la inmigración. Del mismo modo, los que se sienten inseguros en sus barrios y los que creen que la vida de la mayoría de los ciudadanos de su país va a peor, presentan frecuencias altas de rechazo hacia la inmigración. Por último, la actitud restrictiva es también más frecuente entre aquellos que desconfían de la gente y de las instituciones, como el sistema judicial y los partidos políticos.

El control de la relación entre las principales variables socioeconómicas y la dependiente por terceras variables ha mostrado, por su parte, que:

i. El nivel de ingresos no es una variable que afecte a la actitud hacia la inmigración que mantienen los más jóvenes (15-29 años), afectando a los mayores de sesenta años más que al resto de grupos de edad. También tienen mayor incidencia entre quienes tienen bajos estudios, y poca o ninguna incidencia entre quienes tienen estudios superiores.

ii. La relación entre la edad y la actitud hacia la inmigración no es independiente del todo al nivel educativo: entre los que tienen estudios superiores, la actitud permisiva es mayoritaria en todos los grupos de edad (incluido los mayores de sesenta) y las diferencias porcentuales son mínimas.

iii. La situación laboral no es del todo independiente al nivel educativo de los encuestados: sólo los estudiantes mantienen firme su actitud hacia la 
inmigración (mayoritariamente permisiva) con independencia de su nivel educativo. El resto de categorías ve aumentada de forma muy drástica la actitud restrictiva hacia la inmigración conforme se reduce el nivel educativo.

iv. Los ingresos es otra variable que introduce matices en la relación entre la situación laboral y la actitud hacia la inmigración. Las tres categorías que menos ingresan, jubilados/as e incapacitados/as, desempleados/as y amas de casa, son las únicas que se ven afectadas por la variable ingresos: la actitud restrictiva crece de forma muy considerable conforme se reducen los ingresos.

v. Por lo que respecta a la ocupación, las categorías ocupacionales con mayor nivel educativo y mayores ingresos, coinciden con aquellas que muestran una actitud más permisiva hacia la inmigración, y viceversa (con excepción de los militares, que muestran una actitud restrictiva mayoritaria a pesar de ser una de las categorías que mayor mediana de ingresos registra).

vi. La incidencia del nivel educativo en la actitud hacia la inmigración no sólo no desaparece al cruzarla con terceras variables, sino que además explica el comportamiento de éstas en su relación con la actitud hacia la inmigración. La edad y los ingresos tienen un efecto similar, pero con menor intensidad que el nivel educativo de los encuestados.

Con los árboles de segmentación se ha estudiado la interacción entre las principales variables socioeconómicas y político-culturales, mostrando que:

A. Los mayores niveles de actitud restrictiva hacia la entrada de población inmigrante se dan entre: i) jubilados/as e incapacitados/as para el trabajo, de clase baja y mayores de 44 años; ii) entre quienes tienen estudios inferiores e ingresos bajos/medio-bajos; iii) entre quienes siguen la confesión judía y no contestan sobre su ideología o se declaran de derecha.

B. Los mayores niveles de actitud permisiva hacia la entrada de población inmigrante se da entre: i) estudiantes de clase media y alta; ii) entre quienes tienen estudios superiores, son de izquierda y tienen ingresos medio-altos y altos; iii) entre quienes siguen religiones orientales y otras no cristianas menores de 45 años, y protestantes y de otras confesiones cristianas, de izquierda y menores de 45. 
Por último, el análisis por países de Europa Occidental ha mostrado, en primer lugar, diferencias muy significativas entre los quince países considerados. Portugal, Finlandia y Reino Unido fueron los que mostraron un porcentaje mayor de actitud restrictiva hacia la inmigración, mientras que Islandia y Suecia fueron los que más permisivos se mostraron. En cuanto a las valoraciones que del efecto de la inmigración se hacen, Portugal, Reino Unido, Francia e Irlanda son los que dan una valoración negativa en todos los ámbitos considerados: economía, cultura y condiciones de vida. En el otro extremo, Suiza, Noruega e Islandia son los que mejor valoran el efecto de la inmigración en la economía; Finlandia, Suecia e Islandia en la cultura, e Islandia Suecia y Dinamarca, en las condiciones de vida.

El análisis de correlación de las variables contextuales con las variables dependientes -Valoración del efecto de la inmigración-, ha mostrado que el desempleo de larga duración, el crecimiento del PIB, la renta per cápita, la desigualdad de ingresos y el gasto público en educación guardan una correlación estadísticamente significativa y sustancial con la valoración que en cada país se realiza del efecto de la inmigración en la economía, cultura y condiciones de vida del país receptor. Los signos de la correlación muestran que a mejores condiciones socioeconómicas del país, mejor es la valoración del efecto de la inmigración, y viceversa.

Si bien el análisis de correlación muestran que ni la tasa de población inmigrante, ni el porcentaje de voto extremista de derecha, guardan una correlación estadísticamente significativa con la valoración de la inmigración, en ambos casos, los valores de la correlación son positivos y rozando el 0,4 sobre 1 (en la valoración del efecto de la inmigración en la economía). La correlación con la tasa de población inmigrante y el voto extremista es de 0,369 y 0,399 respectivamente, lo que indicaría que los países que mejores valoraciones dan al efecto de la inmigración en la economía, son también los que mayor tasa de población inmigrante y mayor porcentaje de voto extremista registran.

Aunque el valor de la correlación sea relativamente bajo y estadísticamente no significativo, sorprende que los países que cuentan con mayor porcentaje de población inmigrante no sean los que mayor porcentaje de actitud restrictiva ni peor 
valoración dan a la inmigración. Portugal, Finlandia y Dinamarca -el primero, segundo y cuarto país que mayor porcentaje de actitud restrictiva registran-, están entre los cinco países de los considerados con menores tasas de población inmigrante.

El análisis de correlación también muestra que no existe una correlación estadísticamente significativa entre voto extremista, valoración de la inmigración y tasa de población inmigrante: no se puede afirmar entonces que a mayor tasa de población inmigrante, peor valoración de ésta o mayor voto extremista de derecha. De hecho, el valor de la correlación entre voto extremista y tasa de población inmigrante es de 0,354 que, si bien es baja y no significativa, muestra un signo positivo.

Por último, el análisis de correlación ha mostrado que la relación que mantiene la valoración de la inmigración con las variables contextuales de carácter socioeconómicas, es la inversa en el caso del extremismo político: el voto a la extrema derecha se correlaciona de forma negativa con la tasa de desempleo y de forma positiva con la renta per cápita. Lo que indicaría que los partidos políticos de extrema derecha obtienen mejores resultados electorales en los países con menor tasa de desempleo y con mayor renta per cápita, y viceversa. El voto extremista también muestra unos valores de correlación sustanciales y negativos con el índice de desigualdad de ingresos y con el desempleo de larga duración (aunque no pasan por poco, la prueba de significación del 0,05 ), indicando que los partidos de extrema derecha registran mejores resultados en los países con menor desigualdad y menor desempleo de larga duración.

Se confirma entonces la tercera y última hipótesis: se producen diferencias muy significativas en la actitud media hacia la inmigración que mantiene cada país de los analizados. La valoración media del efecto de la inmigración es negativa en diez de los quince países en el ámbito económico y de las condiciones de vida, mientras que la valoración de la cultura es positiva en once de ellos. Respecto a las variables contextuales, no existe una correlación estadísticamente significativa entre la valoración de la inmigración con la tasa de población inmigrante y el mapa del extremismo político de derecha. Dentro de las variables contextuales macroeconómicas y sociales, el desempleo, la desigualdad social, el crecimiento del 
PIB, la renta per cápita y la inversión pública en educación, son las que mantienen una correlación estadísticamente significativa y sustancial con la valoración de la inmigración: a mejor contexto socioeconómico, mejor valoración de la inmigración, y viceversa.

\section{B. PRINCIPALES CONCLUSIONES:}

La estructura de esta investigación ha estado orientada por el esquema propuesto por Martín, Molina y Meardi (2003), que distinguen tres grandes grupos de variables explicativas en los principales estudios sobre actitudes hacia la inmigración: económicas, culturales-ideológicas y contextuales.

En primer lugar, el perfil socioeconómico del rechazo de la inmigración obtenido está en la línea de otros estudios sobre actitudes hacia la inmigración (Díez Nicolás, 2005). Este se caracteriza por un bajo nivel de estudios y de ingresos, clase social baja, inactividad laboral u ocupaciones poco cualificadas y/o manuales y avanzada edad. Este perfil puede hacernos reflexionar en un doble sentido. Por un lado, podría explicarse en clave de competencia entre la población autóctona menos favorecida y la población inmigrante (Solé et al. 2000). Este tipo de rechazo tiene como trasfondo la percepción de amenaza por la competencia en el mercado de trabajo y por las prestaciones sociales, de presión a la baja en las condiciones laborales y de encarecimiento de las viviendas. Desde esta perspectiva, no sorprende que la población inmigrante menos deseable en términos sociales sea la procedente de países pobres, pues se les presupone mayores necesidades por cubrir.

Por otro lado, lo que podría denominarse como "racismo popular" o "racismo de la clase obrera" (Van Dijk, 1993, Balibar y Wallerstein, 1988), puede aparecer sobrerrepresentado en las encuestas y en los medios, por los errores en su medición (Cea D’Anconna, 2002 y 2009), y/o de forma intencionada por las elites para exculpar sus propios prejuicios étnicos.

En segundo lugar, la dimensión cultural e ideológica de las actitudes hacia la inmigración hace referencia por un lado, a la convivencia entre autóctonos e 
inmigrantes, especialmente en términos de adopción de las costumbres y pautas culturales autóctonas por parte de éstos (Rodríguez Monter, 2009). El hecho de que la actitud hacia la inmigración sea más permisiva en el caso de que ésta comparta los rasgos étnico/raciales de la mayoría de la población receptora, demuestra que es más deseable en términos sociales recibir población inmigrante a los que se les presupone una mayor facilidad de integración. Por otro lado, los problemas de los modelos de gestión de la diversidad son politizados por los que son contrarios a las políticas migratorias permisivas, como los partidos de extrema derecha y algunos de centro-derecha. La creciente islamofobia que caracteriza al discurso xenófobo actual en Europa (D’Appollonia, 2007), puede explicarse tanto por la repercusión de los atentados terroristas perpetrados tras el 11 de septiembre de 2001, como por el uso demagógico que han hecho del integrismo musulmán los que se oponen al multiculturalismo en Europa.

En tercer lugar, los contextos de crisis económicas y el aumento de las desigualdades sociales y económicas, favorecen la politización de la inmigración y los discursos anti-inmigración (Cea D’Anconna, 2005). En el análisis de resultados se ha mostrado cómo el desempleo, la desigualdad de ingresos, una menor renta per cápita y decrecimiento del PIB, guarda relación con una peor valoración de la inmigración. Estos contextos socioeconómicos son potencialmente peligrosos si las clases dirigentes e institucionales banalizan la cuestión migratoria y utilizan como chivo expiatorio a la población inmigrante, con el objetivo de exculpar la incapacidad de aquéllos para dar solución a los problemas sociales y económicos.

Queda por saber si la actitud de rechazo hacia la inmigración en la Europa actual se debe a la extensión del racismo o xenofobia propiamente dichos, o si estamos ante una pura discriminación económica, en términos de clase social. Numerosos estudios apuntan a esta última posibilidad (Díez Nicolás, 2005), señalando que tras las diferencias culturales y los discursos xenófobos, se esconden otras de carácter socioeconómicas (Solé et al. 2000). 
En esta investigación, se obtienen datos que permiten hablar tanto de un rechazo hacia la inmigración por pura cuestión económica, como por una cuestión de diferencias culturales. El rechazo mostrado por la inmigración es bastante mayor en el caso de que la población inmigrante proceda de países pobres de fuera de la Unión Europea y menor, si es de la misma raza/grupo étnico que la mayoría. Se podría argumentar que los encuestados se dejaron llevar por la condición de "pobre" del primer grupo de inmigrantes (pues sería una población con mayores necesidades por cubrir), pero el rechazo es también mayor en el caso de que los inmigrantes sean de diferente raza/grupo étnico que la mayoría, sin especificar su perfil socioeconómico. Asimismo, la pregunta sobre la población inmigrante de la misma raza/grupo étnico no desvela el que sea población con mayores o menores recursos, mientras que se sobre-entiende que las personas "pobres de fuera de la UE" no comparten los rasgos culturales y raciales de la mayoría de europeos. Esto haría pensar en una discriminación de la población inmigrante por motivos étnico/raciales. Sin embargo, en la valoración que se hace del impacto de la inmigración en el país receptor, el impacto en el ámbito cultural es el mejor valorados de los tres, y el único que obtiene una puntuación media positiva. Las otras dos, economía y condiciones de vida, obtienen de media una puntuación negativa.

Parece entonces, que el racismo "diferencialista" y el "racismo de clase" (Balibar y Wallerstein, 1991) se entrelazan. El inmigrante excluido es, sobre todo, el procedente de países pobres. Si bien la discriminación o el rechazo pueden tener como causa estructural su posición en la escala social, no es menos cierto que las diferencias culturales son politizadas y utilizadas para crear los prejuicios étnico/raciales y culturales, que tienen la función de reproducir la exclusión. Y aquí es donde entran en escena los actores encargados de construir socialmente la figura del inmigrante.

Las extremas derechas europeas han asignado un significado particular y pernicioso a la inmigración en la construcción de ésta como problema social (en términos de invasión tercermundista e islamista, sobre todo). Los gobernantes, por su parte, hacen de la inmigración el chivo expiatorio de los problemas que son incapaces de 
atajar, tales como el desempleo, el mal funcionamiento de los servicios públicos o la inseguridad ciudadana. Los medios de comunicación permiten la transmisión y difusión de estos significados, extendiendo la percepción de una supuesta avalancha de inmigrantes dirigida hacia Europa. Los medios juegan un papel fundamental en la medida en que lo audiovisual facilita la comprensión de las categorías o significados que se crean en torno a la inmigración.

Estos significados no se quedan en el ámbito de la interpretación, sino que conforman actitudes hacia la inmigración en la población receptora, influyendo finalmente en el comportamiento de ésta. Este comportamiento puede materializarse en forma de discriminación, ya sea sutil o manifiesta, en el voto a formaciones extremistas, en acciones violentas, o en apoyos a las iniciativas gubernamentales con tintes xenófobas.

\section{FUTURAS LÍNEAS DE INVESTIGACIÓN:}

El estudio de las actitudes hacia la inmigración abre un abanico muy amplio de posibles líneas de investigación, desde un estudio más profundo del tipo de actitudes que se mantienen hacia los colectivos inmigrantes, la exteriorización de estas actitudes en acciones o comportamientos, los actores responsables de la construcción social de la inmigración, y los contextos que favorecen actitudes más tolerantes 0 , por el contrario, más xenófobas. En este estudio concreto, quedan abiertas las siguientes líneas de investigación:

- Analizar por qué los niveles de intolerancia hacia los inmigrantes varían de un país a otro, y en el tiempo. Resulta interesante que los niveles de xenofobia o racismo no se correspondan siempre con los países con mayor tasa de población inmigrante.

- Analizar la relación entre xenofobia y extremismos: la geografía de la xenofobia no coincide siempre con la geografía del extremismo político. Los países con altos niveles de racismo o xenofobia no se corresponden siempre con países que cuentan con partidos de extrema derecha sólidos, ni con grupos extremistas altamente organizados. Si bien los programas políticos de estos partidos no están centrados de forma exclusiva en el discurso anti- 
inmigración, si es cierto que éste es uno de sus ejes principales (junto a la denuncia de la corrupción de los partidos tradicionales y la pérdida de soberanía nacional por la integración europea).

- Profundizar en la incidencia que el contexto socio-económico tiene en la conformación de las actitudes hacia la inmigración: el estudio ha mostrado que los países más desarrollados muestran porcentajes más bajos de actitud restrictiva hacia la inmigración y, sin embargo, coinciden en buena parte de los casos con los países que cuentan con los partidos de extrema derecha más sólidos. En el estudio se ha hecho referencia a los problemas de medición de las actitudes xenófobas y racistas a través de la encuesta. ¿Es posible que los países más desarrollados sean más vulnerables al sesgo de la deseabilidad social y que por ello queden menos representadas las actitudes reacias a la inmigración que en el resto de países?

- Comprender el círculo vicioso que se produce entre el discurso político institucional, medios de comunicación, partidos y organizaciones extremistas. Mientras gobernantes y partidos tradicionales denuncian públicamente los discursos extremistas y los acontecimientos violentos o discriminatorios dirigidos a la población inmigrante, hacen de ésta su chivo expiatorio en momentos de crisis para obtener réditos electorales. Al mismo tiempo, el avance en las políticas migratorias restrictivas van legitimando y fortaleciendo a los extremistas, que toman estas medidas como pequeñas victorias. Los medios de comunicación, por su parte, se encargan de reproducir los discursos anti-inmigración, criminalizando la imagen del inmigrante, al tiempo que denuncian las posturas extremistas. A largo plazo, estas pequeñas acciones van calando profundamente en el imaginario colectivo de la población autóctona, sembrando el campo electoral a las formaciones de extrema derecha y al discurso xenófobo.

\section{APLICABILIDAD DE LOS RESULTADOS:}

Si bien el debate en torno a los cambios socio-demográficos que los países europeos han experimentado en los últimos años son perfectamente legítimos y necesarios, la banalización y uso demagógico de la cuestión migratoria por parte de 
instituciones públicas, partidos políticos, medios de comunicación y otros agentes sociales son potencialmente peligrosos. Por un lado, están allanando el terreno a las formaciones extremistas (Simón, 2007), y por otro, multiplican los riesgos de aparición de conflicto social, violencia y discriminación (Morales y Ros, 2012). Son utilizados para exculpar y disimular las incapacidades de los gobiernos de hacer frente a los problemas estructurales de Europa como el desempleo, así como para disimular los prejuicios étnicos de las élites (Van Dijk, 1993).

En cualquier caso, los estudios de las actitudes de rechazo hacia la inmigración, los factores que las propician, tanto individuales como contextuales, y el análisis de su politización por los diversos actores político-sociales, son absolutamente necesarios para intervenir (desde un punto de vista educativo, social y económico) sobre un problema que tiene el potencial de legitimar un clima de exclusión y discriminación social, en base a la procedencia y a las diferencias étnico/raciales y culturales. 


\section{BIBLIOGRAFÍA}

Balibar, E y Wallerstein, I. (1991). Raza, nación y clase, Madrid: IEPALA

Bruquetas Callejo, M. y Moreno Fuentes, F. J.: Inmigración y Estado de Bienestar en España, Obra Social La Caixa, Colección de Estudios Sociales, Núm. 31, 2011

Burkhardt, C. y Mau, S. (2009). Migration and welfare state solidarity in Western Europe. Journal of European Social Policy, 19; 213

Casals Meseguer, X. (2003). Ultrapatriotas. Extrema derecha y nacionalismo de la Guerra Fría a la era de la globalización, Madrid: Editorial Crítica

Cea D'Ancona, M.A. (2002). La medición de las actitudes ante la inmigración: Evaluación de los indicadores tradicionales de racismo. Revista Española de Investigaciones Sociológicas (REIS), № 99, pp. 87-112

Cea D’Ancona, M. A. (2005). La exteriorización de la xenofobia. Revista Española de Investigaciones Sociológicas (REIS), № 112, pp. 197-230

Cea D’Ancona, M. A. (2009). La compleja detección del racismo y la xenofobia a través de encuesta. Un paso adelante en su medición. Revista Española de Investigaciones Sociológicas (REIS), nº 125, pp.13-45

Cea D’Ancona, M.A.; Vallés, M.S. (2010). Evolución del racismo y la xenofobia en España. Informe 2010. Ministerio de Trabajo e Inmigración

Colectivo IOÉ (1998). Inmigración y trabajo. Trabajadores inmigrantes en el sector de la construcción. Colectivo Observatorio Permanente de la Inmigración, № 1 , Madrid: IMSERSO

D’Appollonia, A. (2007). Xenofobia y extremas derechas en Europa. En Simón, M.A., (Ed): La extrema derecha en Europa desde 1945 a nuestros días, (pp. 187-203) Madrid: Tecnos 
Díez Nicolás, J. (2005). Las dos caras de la inmigración, Documentos del Observatorio Permanente de la Inmigración, № 3, Madrid: Ministerio de Trabajo y Asuntos Sociales

Escobar Mercado, M. (2007). El análisis de segmentación: técnicas y aplicaciones de los árboles de clasificación, Madrid: Centro de Investigaciones Sociológicas

Flecha, R. (2001). Racismo moderno y postmoderno en Europa: un enfoque dialógico y pedagogías antirracistas, Revista Española de Investigaciones Sociológicas (REIS), no 94/01 - pp. 79-103

Flecha, R., Gómez, J., Puigvert, L. (2001). Teoría sociológica contemporánea. Barcelona: Paidós Studio

Front National. Notre Projet. Programme politique du Front National. Descargado de www.frontnational.com/pdf/programme/pdf

García Borrego, I. (2005). La construcción social de la inmigración: el papel de la universidad en La condición del inmigrante (coordinadores Andrés Pedreño Cánovas, Manuel Hernández Pedreño). Murcia: Universidad de Murcia.

Giménez, C. y Malgesini, G. (2000). Guía de conceptos sobre migraciones, racismo e interculturalidad. Madrid: Libros de Catarata

Innerarity, C.; Acha, B. (2010). Los discursos sobe ciudadanía e inmigración en Europea: Universalismo, extremismo y educación. Revista Política y Sociedad, vol. 47, no 2, pp.63-84.

Izquierdo, A. (1995). La inmigración inesperada. Madrid: Trotta

López-Aranguen, E. (2005). Problemas sociales. Desigualdad, pobreza, exclusión social. Madrid: Biblioteca Nueva

Mayda, A.M. (2006). Who is Against Immigration? Review of Economic and Statistics, August 88 (2006), pp.510-530.

Martín Artiles, A., Molina, O., y Meardi, G. (2013). Incertidumbre socio-económica y actitudes hacia la inmigración en Europa, Cuadernos de Relaciones Laborales, Vol. 31, Num. 1, 167-194 
Martínez Cuadrado, M. y Mella Márquez, M. (Ed) (2012). Partidos políticos y sistemas de partidos, Madrid: Trotta

Morales, L. y Ros, V. (2012). La politización de la inmigración en España en perspectiva comparada, Documentos CIDOB, Migraciones, ํํ 25

Naïr, S. (2010). La Europa mestiza. Inmigración, ciudadanía, codesarrollo. Barcelona: Galaxia Gutenberg

Parlamento Europeo. Comisión de Investigación del Racismo y la Xenofobia (1991). Informe Ford sobre el racismo en Europa: Madrid, Instituto Nacional de Servicios Sociales

Rodríguez Monter, M. (2009). Los valores culturales y el fenómeno de las migraciones internacionales. Athenea Digital, ํㅜ 15, 217-228

Sáchez Carrión, J. J. (1999). Manual de análisis estadístico de los datos, Madrid: Alianza Editorial

Simón, M.A., (Ed) (2007). La extrema derecha en Europa desde 1945 a nuestros días, Madrid: Tecnos

Sobrados León, M. (2011). La inmigración como problema. Percepciones sociales y representaciones mediáticas, Prisma Social, № 6

Solé, C.; Parella; S. Alarcón, A.; Bergalli, V.; Gibert, F. (2000). El impacto de la inmigración en la sociedad receptora. Revista Española de Investigaciones Sociológicas (REIS), ㄲo 90, 131-157

Traverso, E. (2011). La fábrica del odio. Xenofobia y racismo en Europa, El Viejo Topo 285/octubre.

http://www.elviejotopo.com/web/archivo revista.php?arch=1646.pdff

UDC-SVP. SVP-The party for Switzerland. Party programme 2011-2015. Descargado de www.udc.ch/positions/programme/politique/

United Kingdom Independence Party. Create an earthquake. UKIP Manifiesto 2014. Descargado de www.ukip.org 
Van Dijk, T. A. (1987). Communicating racism. Ethnic prejudice in thought and talk, London: SAGE Publications

Van Dijk, T. A. (1993). El racismo de la elite. Archipiélago, oํ 14, 106-111

Van Dijk, T. A. (2005). Nuevo racismo y noticias. Un enfoque discursivo. En Benach, N., Nash, M., Tello i Rovira, R. (Ed.) Inmigración, género y espacios urbanos: Ios retos de la diversidad (pp. 33-56). Barcelona: Ed. Bellaterra 


\section{ANEXO № 1: ACTITUD HACIA LA INMIGRACIÓN Y VALORACIÓN EFECTO DE LA INMIGRACIÓN}

\begin{tabular}{|c|c|c|c|}
\hline \multicolumn{4}{|c|}{ Tabla I.I. Evolución "Actitud hacia la inmigración" (Total N válido) } \\
\hline & $\begin{array}{c}\text { Inmigrantes de la misma } \\
\text { raza/grupo étnico que la } \\
\text { mayoría }\end{array}$ & $\begin{array}{c}\text { Inmigrantes de diferente } \\
\text { raza/grupo étnico que la } \\
\text { mayoría }\end{array}$ & $\begin{array}{c}\text { Inmigrantes procedentes } \\
\text { de países pobres de fuera } \\
\text { de la UE }\end{array}$ \\
\hline 2012 & 52405 & 52262 & 52023 \\
\hline 2010 & 50483 & 50349 & 50102 \\
\hline 2008 & 54438 & 54200 & 53814 \\
\hline 2006 & 41599 & 41465 & 41138 \\
\hline 2004 & 45870 & 45738 & 45577 \\
\hline 2002 & 40317 & 40263 & 40179 \\
\hline
\end{tabular}

Fuente: elaboración propia a partir de la ESE 2002-2012

\begin{tabular}{|cccc|}
\hline & $\begin{array}{c}\text { Tabla I.II. Evolución "Actitud hacia la inmigración" } \\
\text { Inmigrantes de la misma } \\
\text { raza/grupo étnico que la } \\
\text { mayoría }\end{array}$ & $\begin{array}{c}\text { Inmigrantes de diferente } \\
\text { raza/grupo étnico que la } \\
\text { mayoría }\end{array}$ & $\begin{array}{c}\text { Inmigrantes procedentes } \\
\text { de países pobres de fuera } \\
\text { de la UE }\end{array}$ \\
\hline $\mathbf{2 0 1 2}$ & 4,1 & 4,4 & 4,8 \\
\hline $\mathbf{2 0 1 0}$ & 3,8 & 4 & 4,5 \\
\hline $\mathbf{2 0 0 8}$ & 4,1 & 4,5 & 5,2 \\
\hline $\mathbf{2 0 0 6}$ & 3,3 & 3,6 & 4,3 \\
\hline $\mathbf{2 0 0 4}$ & 3,5 & 3,8 & 4,1 \\
\hline $\mathbf{2 0 0 2}$ & 4,8 & 4,9 & 5,1 \\
\hline \multicolumn{4}{r}{} \\
\hline
\end{tabular}

Fuente: elaboración propia a partir de la ESE 2002-2012

\begin{tabular}{|cccc|}
\hline \multicolumn{3}{|c|}{$\begin{array}{c}\text { Tabla I.III. Valoración efecto de la inmigración (Total } \\
\text { N válido) }\end{array}$} \\
\hline $\mathbf{2 0 1 2}$ & 51769 & 51884 & $\begin{array}{c}\text { Lugar para } \\
\text { vivir }\end{array}$ \\
\hline $\mathbf{2 0 1 0}$ & 49719 & 49778 & 49379 \\
\hline $\mathbf{2 0 0 8}$ & 53515 & 53548 & 53285 \\
\hline $\mathbf{2 0 0 6}$ & 40437 & 40568 & 40469 \\
\hline $\mathbf{2 0 0 4}$ & 44833 & 44933 & 44648 \\
\hline $\mathbf{2 0 0 2}$ & 39769 & 39969 & 40164 \\
\hline
\end{tabular}

Fuente: elaboración propia a partir de la ESE 2002-2012

\begin{tabular}{|cccc|}
\hline & $\begin{array}{c}\text { Tabla I.IV. Valoración efecto de la inmigración (\% } \\
\text { casos perdidos) }\end{array}$ & $\begin{array}{c}\text { Economía } \\
\text { Cultura }\end{array}$ & $\begin{array}{c}\text { Luara } \\
\text { vivir }\end{array}$ \\
\hline $\mathbf{2 0 1 2}$ & 5,3 & 5,1 & 5,7 \\
\hline $\mathbf{2 0 1 0}$ & 5,2 & 5,1 & 5,9 \\
\hline $\mathbf{2 0 0 8}$ & 5,7 & 5,6 & 6,1 \\
\hline $\mathbf{2 0 0 6}$ & 6 & 5,7 & 5,9 \\
\hline $\mathbf{2 0 0 4}$ & 5,7 & 5,5 & 6,1 \\
\hline $\mathbf{2 0 0 2}$ & 6,1 & 5,6 & 5,2 \\
\hline
\end{tabular}

Fuente: elaboración propia a partir de la ESE 2002-2012 
ANEXO 2.1: TABLAS DE CONTINGENCIA VARIABLES SOCIOECONÓMICAS / VARIABLE DEPENDIENTE: “ACTITUD HACIA LA INMIGRACIÓN PROCEDENTE DE PAÍSES POBRES DE FUERA DE LA UE".

Tabla de contingencia: Género/Actitud hacia la inmigración

\begin{tabular}{|c|c|c|c|c|c|}
\hline & & & \multicolumn{2}{|c|}{ Actitud hacia la inmigración } & \multirow{2}{*}{ Total } \\
\hline & & & Permisiva & Restrictiva & \\
\hline \multirow[t]{4}{*}{ Género } & Hombre & Recuento & 11321 & 12624 & 23945 \\
\hline & & $\%$ & $47,3 \%$ & $52,7 \%$ & $100,0 \%$ \\
\hline & Mujer & Recuento & 13171 & 14891 & 28062 \\
\hline & & $\%$ & $46,9 \%$ & $53,1 \%$ & $100,0 \%$ \\
\hline \multirow[t]{2}{*}{ Total } & & Recuento & 24492 & 27515 & 52007 \\
\hline & & $\%$ & $47,1 \%$ & $52,9 \%$ & $100,0 \%$ \\
\hline
\end{tabular}

Fuente: Elaboración propia a partir de la ESE 2012

Tabla de contingencia: Edad/Actitud hacia la inmigración

\begin{tabular}{|c|c|c|c|c|c|}
\hline & & & \multicolumn{2}{|c|}{ Actitud hacia la inmigración } & \multirow{2}{*}{ Total } \\
\hline & & & Permisiva & Restrictiva & \\
\hline \multirow[t]{8}{*}{ Edad } & $15-29$ & Recuento & 5625 & 4588 & 10213 \\
\hline & & $\%$ & $55,1 \%$ & $44,9 \%$ & $100,0 \%$ \\
\hline & \multirow[t]{2}{*}{$30-44$} & Recuento & 6406 & 6146 & 12552 \\
\hline & & $\%$ & $51,0 \%$ & $49,0 \%$ & $100,0 \%$ \\
\hline & \multirow[t]{2}{*}{$45-59$} & Recuento & 6226 & 7076 & 13302 \\
\hline & & $\%$ & $46,8 \%$ & $53,2 \%$ & $100,0 \%$ \\
\hline & \multirow[t]{2}{*}{$>60$} & Recuento & 6195 & 9645 & 15840 \\
\hline & & $\%$ & $39,1 \%$ & $60,9 \%$ & $100,0 \%$ \\
\hline
\end{tabular}




\begin{tabular}{|c|c|c|c|c|}
\hline \multirow[t]{2}{*}{ Total } & Recuento & 24452 & 27455 & 51907 \\
\hline & $\%$ & $47,1 \%$ & $52,9 \%$ & $100,0 \%$ \\
\hline
\end{tabular}

Fuente: Elaboración propia a partir de la ESE 2012

Tabla de contingencia: Estado civil/Actitud hacia la inmigración

\begin{tabular}{|c|c|c|c|c|c|}
\hline & & & \multicolumn{2}{|c|}{ Actitud Hacia la inmigración } & \multirow{2}{*}{ Total } \\
\hline & & & Permisiva & Restrictiva & \\
\hline \multirow[t]{8}{*}{ Estado civil } & Casado/a, pareja de hecho & Recuento & 12210 & 14374 & 26584 \\
\hline & & $\%$ & $45,9 \%$ & $54,1 \%$ & $100,0 \%$ \\
\hline & Divorciado/a, separado/a & Recuento & 2177 & 2915 & 5092 \\
\hline & & $\%$ & $42,8 \%$ & $57,2 \%$ & $100,0 \%$ \\
\hline & Viudo/a & Recuento & 1725 & 3169 & 4894 \\
\hline & & $\%$ & $35,2 \%$ & $64,8 \%$ & $100,0 \%$ \\
\hline & Soltero/a & Recuento & 8130 & 6752 & 14882 \\
\hline & & $\%$ & $54,6 \%$ & $45,4 \%$ & $100,0 \%$ \\
\hline \multirow[t]{2}{*}{ Total } & & Recuento & 24242 & 27210 & 51452 \\
\hline & & $\%$ & $47,1 \%$ & $52,9 \%$ & $100,0 \%$ \\
\hline
\end{tabular}

Fuente: Elaboración propia a partir de la ESE 2012

Tabla de contingencia: Nivel de estudios/Actitud hacia la inmigración

\begin{tabular}{|lc|c|c|c|}
\hline \multirow{2}{*}{} & \multicolumn{2}{|c|}{ Actitud hacia la inmigración } & \multirow{2}{*}{ Total } \\
\cline { 2 - 4 } & Permisiva & Restrictiva & \\
\hline Nivel de $\quad$ Estudios primarios o sin Recuento & 2594 & 4560 & \multirow{2}{*}{7154} \\
\hline
\end{tabular}




\begin{tabular}{|lll|c|c|c|}
\hline estudios & estudios & & $36,3 \%$ & $63,7 \%$ & $100,0 \%$ \\
\cline { 2 - 6 } & Estudios secundarios & Recuento & 12974 & 16018 & 28992 \\
& $\%$ & $44,8 \%$ & $55,2 \%$ & $100,0 \%$ \\
\hline Estudios superiores & Recuento & 8762 & 6729 & 15491 \\
& $\%$ & $56,6 \%$ & $43,4 \%$ & $100,0 \%$ \\
\hline Total & $\%$ & 24330 & 27307 & 51637 \\
& & & $47,1 \%$ & $52,9 \%$ & $100,0 \%$ \\
\hline
\end{tabular}

Fuente: Elaboración propia a partir de la ESE 2012

Tabla de contingencia: Situación laboral/Actitud hacia la inmigración

\begin{tabular}{|c|c|c|c|c|c|}
\hline & & & \multicolumn{2}{|c|}{ Actitud hacia la inmigración } & \multirow{2}{*}{ Total } \\
\hline & & & Permisiva & Restrictiva & \\
\hline \multirow[t]{12}{*}{ Situación Laboral } & Trabajo remunerado & Recuento & 12412 & 12361 & 24773 \\
\hline & & $\%$ & $50,1 \%$ & $49,9 \%$ & $100,0 \%$ \\
\hline & Estudiante & Recuento & 2759 & 1739 & 4498 \\
\hline & & $\%$ & $61,3 \%$ & $38,7 \%$ & $100,0 \%$ \\
\hline & Desempleado/a & Recuento & 1717 & 2198 & 3915 \\
\hline & & $\%$ & $43,9 \%$ & $56,1 \%$ & $100,0 \%$ \\
\hline & $\begin{array}{l}\text { Jubilado/a o incapacitado/a para el } \\
\text { trabajo }\end{array}$ & Recuento & 5074 & 8194 & 13268 \\
\hline & & $\%$ & $38,2 \%$ & $61,8 \%$ & $100,0 \%$ \\
\hline & $\begin{array}{l}\text { Labores del hogar y/o cuidados de } \\
\text { familiares }\end{array}$ & Recuento & 2053 & 2426 & 4479 \\
\hline & & $\%$ & $45,8 \%$ & $54,2 \%$ & $100,0 \%$ \\
\hline & Otros & Recuento & 285 & 286 & 571 \\
\hline & & $\%$ & $49,9 \%$ & $50,1 \%$ & $100,0 \%$ \\
\hline
\end{tabular}




\begin{tabular}{|l|l|l|l|l|} 
Total & Recuento & 24300 & 27204 & 51504 \\
& $\%$ & $47,2 \%$ & $52,8 \%$ & $100,0 \%$ \\
\hline
\end{tabular}

Fuente: Elaboración propia a partir de la ESE 2012

Tabla de contingencia: Ocupación/Actitud hacia la inmigración

\begin{tabular}{|c|c|c|c|c|c|}
\hline & & & \multicolumn{2}{|c|}{ Actitud hacia la inmigración } & \multirow{2}{*}{ Total } \\
\hline & & & Permisiva & Restrictiva & \\
\hline \multirow[t]{17}{*}{ Ocupación } & Ocupaciones militares & Recuento & 80 & 91 & 171 \\
\hline & & Recuento & $46,8 \%$ & $53,2 \%$ & $100,0 \%$ \\
\hline & Gerentes & $\%$ & 1797 & 1463 & 3260 \\
\hline & & Recuento & $55,1 \%$ & $44,9 \%$ & $100,0 \%$ \\
\hline & Profesionales & $\%$ & 4623 & 3257 & 7880 \\
\hline & & Recuento & $58,7 \%$ & $41,3 \%$ & $100,0 \%$ \\
\hline & Técnicos y profesionales de nivel medio & $\%$ & 3213 & 3166 & 6379 \\
\hline & & Recuento & $50,4 \%$ & $49,6 \%$ & $100,0 \%$ \\
\hline & Personal de apoyo administrativo & $\%$ & 1837 & 2146 & 3983 \\
\hline & & Recuento & $46,1 \%$ & $53,9 \%$ & $100,0 \%$ \\
\hline & Trabajadores de los servicios y de & $\%$ & 3943 & 4721 & 8664 \\
\hline & & Recuento & $45,5 \%$ & $54,5 \%$ & $100,0 \%$ \\
\hline & $\begin{array}{l}\text { Trabajadores expertos en agricultura, } \\
\text { pesca y forestal }\end{array}$ & $\%$ & 518 & 754 & 1272 \\
\hline & & Recuento & $40,7 \%$ & $59,3 \%$ & $100,0 \%$ \\
\hline & Artesanía y otros oficios & $\%$ & 2200 & 3300 & 5500 \\
\hline & & Recuento & $40,0 \%$ & $60,0 \%$ & $100,0 \%$ \\
\hline & Operadores de instalaciones y & $\%$ & 1529 & 2459 & 3988 \\
\hline
\end{tabular}




\begin{tabular}{|c|c|c|c|c|c|}
\hline & máquinas & Recuento & $38,3 \%$ & $61,7 \%$ & $100,0 \%$ \\
\hline & Ocupaciones elementales & $\%$ & 2078 & 2994 & 5072 \\
\hline & & Recuento & $41,0 \%$ & $59,0 \%$ & $100,0 \%$ \\
\hline Total & & Recuento & 21818 & 24351 & 46169 \\
\hline & & $\%$ & $47,3 \%$ & $52,7 \%$ & $100,0 \%$ \\
\hline
\end{tabular}

Fuente: Elaboración propia a partir de la ESE 2012

Tabla de contingencia: Ingresos/Actitud hacia la inmigración

\begin{tabular}{|c|c|c|c|c|c|}
\hline & & & \multicolumn{2}{|c|}{ Actitud hacia la inmigración } & \multirow{2}{*}{ Total } \\
\hline & & & Permisiva & Restrictiva & \\
\hline \multirow[t]{8}{*}{ Ingresos } & Bajos & Recuento & 4124 & 5504 & 9628 \\
\hline & & $\%$ & $42,8 \%$ & $57,2 \%$ & $100,0 \%$ \\
\hline & Medio-bajos & Recuento & 6286 & 7543 & 13829 \\
\hline & & $\%$ & $45,5 \%$ & $54,5 \%$ & $100,0 \%$ \\
\hline & Medio-altos & Recuento & 6046 & 5801 & 11847 \\
\hline & & $\%$ & $51,0 \%$ & $49,0 \%$ & $100,0 \%$ \\
\hline & Altos & Recuento & 3824 & 2968 & 6792 \\
\hline & & $\%$ & $56,3 \%$ & $43,7 \%$ & $100,0 \%$ \\
\hline \multirow[t]{2}{*}{ Total } & & Recuento & 20280 & 21816 & 42096 \\
\hline & & $\%$ & $48,2 \%$ & $51,8 \%$ & $100,0 \%$ \\
\hline
\end{tabular}

Fuente: Elaboración propia a partir de la ESE 2012 
Tabla de contingencia: Clase social subjetiva/Actitud hacia la inmigración

\begin{tabular}{|c|c|c|c|c|c|}
\hline & & & \multicolumn{2}{|c|}{ Actitud hacia la inmigración } & \multirow{2}{*}{ Total } \\
\hline & & & Permisiva & Restrictiva & \\
\hline \multirow[t]{10}{*}{ Clase social subjetiva } & Baja & Recuento & 1148 & 2033 & 3181 \\
\hline & & $\%$ & $36,1 \%$ & $63,9 \%$ & $100,0 \%$ \\
\hline & Media-baja & Recuento & 3769 & 5370 & 9139 \\
\hline & & $\%$ & $41,2 \%$ & $58,8 \%$ & $100,0 \%$ \\
\hline & Media & Recuento & 6475 & 7795 & 14270 \\
\hline & & $\%$ & $45,4 \%$ & $54,6 \%$ & $100,0 \%$ \\
\hline & Media-alta & Recuento & 9159 & 8592 & 17751 \\
\hline & & $\%$ & $51,6 \%$ & $48,4 \%$ & $100,0 \%$ \\
\hline & Alta & Recuento & 3519 & 3152 & 6671 \\
\hline & & $\%$ & $52,8 \%$ & $47,2 \%$ & $100,0 \%$ \\
\hline \multirow[t]{2}{*}{ Total } & & Recuento & 24070 & 26942 & 51012 \\
\hline & & $\%$ & $47,2 \%$ & $52,8 \%$ & $100,0 \%$ \\
\hline
\end{tabular}

Fuente: Elaboración propia a partir de la ESE 2012

Tabla de contingencia: Nacionalidad/Actitud hacia la inmigración

\begin{tabular}{|c|c|c|c|c|c|}
\hline & & & \multicolumn{2}{|c|}{ Actitud hacia la inmigración } & \multirow{2}{*}{ Total } \\
\hline & & & Permisiva & Restrictiva & \\
\hline \multirow{4}{*}{$\begin{array}{l}\text { Nacionalidad del país } S \\
\text { donde habita }\end{array}$} & Sí & Recuento & 23243 & 26599 & 49842 \\
\hline & & $\%$ & $46,6 \%$ & $53,4 \%$ & $100,0 \%$ \\
\hline & No & Recuento & 1249 & 901 & 2150 \\
\hline & & $\%$ & $58,1 \%$ & $41,9 \%$ & $100,0 \%$ \\
\hline Total & & Recuento & 24492 & 27500 & 51992 \\
\hline
\end{tabular}




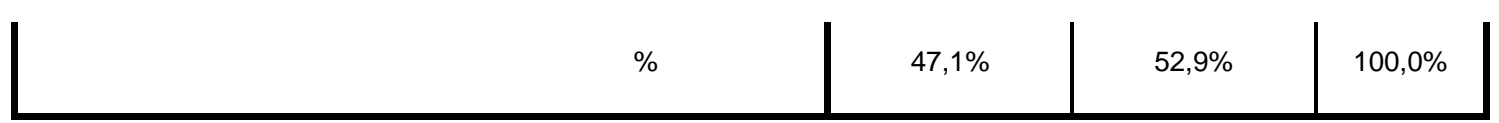

Fuente: Elaboración propia a partir de la ESE 2012

Tabla de contingencia: Lugar residencia/Actitud hacia la inmigración

\begin{tabular}{|c|c|c|c|c|c|}
\hline & & & \multicolumn{2}{|c|}{ Actitud hacia la inmigración } & \multirow{2}{*}{ Total } \\
\hline & & & Permisiva & Restrictiva & \\
\hline \multirow[t]{8}{*}{ Lugar de residencia } & En la gran ciudad & Recuento & 5588 & 6602 & 12190 \\
\hline & & $\%$ & $45,8 \%$ & $54,2 \%$ & $100,0 \%$ \\
\hline & $\begin{array}{l}\text { A las afueras o suburbios de } \\
\text { una gran ciudad }\end{array}$ & Recuento & 2949 & 2577 & 5526 \\
\hline & & $\%$ & $53,4 \%$ & $46,6 \%$ & $100,0 \%$ \\
\hline & $\begin{array}{l}\text { En una ciudad de tamaño } \\
\text { mediio/pequeño }\end{array}$ & Recuento & 7505 & 8562 & 16067 \\
\hline & & $\%$ & $46,7 \%$ & $53,3 \%$ & $100,0 \%$ \\
\hline & $\begin{array}{l}\text { En un pueblo o casa en el } \\
\text { campo }\end{array}$ & Recuento & 8399 & 9717 & 18116 \\
\hline & & $\%$ & $46,4 \%$ & $53,6 \%$ & $100,0 \%$ \\
\hline \multirow[t]{2}{*}{ Total } & & Recuento & 24441 & 27458 & 51899 \\
\hline & & $\%$ & $47,1 \%$ & $52,9 \%$ & $100,0 \%$ \\
\hline
\end{tabular}

Fuente: Elaboración propia a partir de la ESE 2012 
ANEXO 2.2.: TABLAS DE CONTINGENCIA VARIABLES POLÍTICO-CULTURALES / VARIABLE DEPENDIENTE: “ACTITUD HACIA LA INMIGRACIÓN PROCEDENTE DE PAÍSES POBRES DE FUERA DE LA UE"

Tabla de contingencia: Ideología/Actitud hacia la inmigración

\begin{tabular}{|c|c|c|c|c|c|}
\hline & & & \multicolumn{2}{|c|}{ Actitud hacia la inmigración } & \multirow{2}{*}{ Total } \\
\hline & & & Permisiva & Restrictiva & \\
\hline \multirow[t]{12}{*}{ Ideología } & Extrema izquierda & Recuento & 1546 & 1461 & 3007 \\
\hline & & $\%$ & $51,4 \%$ & $48,6 \%$ & $100,0 \%$ \\
\hline & Centro-izquierda & Recuento & 5919 & 4450 & 10369 \\
\hline & & $\%$ & $57,1 \%$ & $42,9 \%$ & $100,0 \%$ \\
\hline & Centro & Recuento & 6891 & 7887 & 14778 \\
\hline & & $\%$ & $46,6 \%$ & $53,4 \%$ & $100,0 \%$ \\
\hline & Centro-derecha & Recuento & 5850 & 7047 & 12897 \\
\hline & & $\%$ & $45,4 \%$ & $54,6 \%$ & $100,0 \%$ \\
\hline & Extrema derecha & Recuento & 1452 & 2394 & 3846 \\
\hline & & $\%$ & $37,8 \%$ & $62,2 \%$ & $100,0 \%$ \\
\hline & No sabe/no contesta & Recuento & 2844 & 4282 & 7126 \\
\hline & & $\%$ & $39,9 \%$ & $60,1 \%$ & $100,0 \%$ \\
\hline \multirow[t]{2}{*}{ Total } & & Recuento & 24502 & 27521 & 52023 \\
\hline & & $\%$ & $47,1 \%$ & $52,9 \%$ & $100,0 \%$ \\
\hline
\end{tabular}

Fuente: Elaboración propia a partir de la ESE 2012 
Tabla de contingencia: Confesión religiosa/Actitud hacia la inmigración

\begin{tabular}{|c|c|c|c|c|c|}
\hline & & & \multicolumn{2}{|c|}{ Actitud hacia la inmigración } & \multirow{2}{*}{ Total } \\
\hline & & & Permisiva & Restrictiva & \\
\hline \multirow{14}{*}{$\begin{array}{l}\text { Confesión } \\
\text { Religiosa }\end{array}$} & Católica & Recuento & 6855 & 7475 & 14330 \\
\hline & & $\%$ & $47,8 \%$ & $52,2 \%$ & $100,0 \%$ \\
\hline & Protestante & Recuento & 3111 & 3051 & 6162 \\
\hline & & $\%$ & $50,5 \%$ & $49,5 \%$ & $100,0 \%$ \\
\hline & Ortodoxa & Recuento & 1988 & 3697 & 5685 \\
\hline & & $\%$ & $35,0 \%$ & $65,0 \%$ & $100,0 \%$ \\
\hline & $\begin{array}{l}\text { Otras confesiones } \\
\text { cristianas }\end{array}$ & Recuento & 338 & 290 & 628 \\
\hline & & $\%$ & $53,8 \%$ & $46,2 \%$ & $100,0 \%$ \\
\hline & Judía & Recuento & 499 & 1482 & 1981 \\
\hline & & $\%$ & $25,2 \%$ & $74,8 \%$ & $100,0 \%$ \\
\hline & Musulmana & Recuento & 1276 & 1415 & 2691 \\
\hline & & $\%$ & $47,4 \%$ & $52,6 \%$ & $100,0 \%$ \\
\hline & $\begin{array}{l}\text { Religiones orientales y } \\
\text { otras no cristianas }\end{array}$ & Recuento & 228 & 115 & 343 \\
\hline & & $\%$ & $66,5 \%$ & $33,5 \%$ & $100,0 \%$ \\
\hline \multirow[t]{2}{*}{ Total } & & Recuento & 14295 & 17525 & 31820 \\
\hline & & $\%$ & $44,9 \%$ & $55,1 \%$ & $100,0 \%$ \\
\hline
\end{tabular}

Fuente: Elaboración propia a partir de la ESE 2012 
Tabla de contingencia: Interés por la política/Actitud hacia la inmigración

\begin{tabular}{|c|c|c|c|c|c|}
\hline & & & \multicolumn{2}{|c|}{ Actitud hacia la inmigración } & \multirow{2}{*}{ Total } \\
\hline & & & Permisiva & Restrictiva & \\
\hline \multirow{4}{*}{$\begin{array}{l}\text { Interés por la } \\
\text { política }\end{array}$} & Mucho o bastante & Recuento & 12280 & 11194 & 23474 \\
\hline & & $\%$ & $52,3 \%$ & $47,7 \%$ & $100,0 \%$ \\
\hline & Poco o nada & Recuento & 12123 & 16214 & 28337 \\
\hline & & $\%$ & $42,8 \%$ & $57,2 \%$ & $100,0 \%$ \\
\hline \multirow[t]{2}{*}{ Total } & & Recuento & 24403 & 27408 & 51811 \\
\hline & & $\%$ & $47,1 \%$ & $52,9 \%$ & $100,0 \%$ \\
\hline
\end{tabular}

Fuente: Elaboración propia a partir de la ESE 2012

Tabla de contingencia: Confianza en la gente/Actitud hacia la inmigración

\begin{tabular}{|c|c|c|c|c|c|}
\hline & & & \multicolumn{2}{|c|}{ Actitud hacia la inmigración } & \multirow[b]{2}{*}{ Total } \\
\hline & & & Permisiva & Restrictiva & \\
\hline \multirow{10}{*}{$\begin{array}{l}\text { Confianza en la } \\
\text { gente }\end{array}$} & Muy desconfiado & Recuento & 3389 & 5996 & 9385 \\
\hline & & $\%$ & $36,1 \%$ & $63,9 \%$ & $100,0 \%$ \\
\hline & Desconfiado & Recuento & 4406 & 6100 & 10506 \\
\hline & & $\%$ & $41,9 \%$ & $58,1 \%$ & $100,0 \%$ \\
\hline & $\begin{array}{l}\text { Ni desconfiado, ni } \\
\text { confiado }\end{array}$ & Recuento & 4611 & 5358 & 9969 \\
\hline & & $\%$ & $46,3 \%$ & $53,7 \%$ & $100,0 \%$ \\
\hline & Confiado & Recuento & 7298 & 6349 & 13647 \\
\hline & & $\%$ & $53,5 \%$ & $46,5 \%$ & $100,0 \%$ \\
\hline & Muy confiado & Recuento & 4738 & 3611 & 8349 \\
\hline & & $\%$ & $56,7 \%$ & $43,3 \%$ & $100,0 \%$ \\
\hline
\end{tabular}




\begin{tabular}{|ll|l|l|l|} 
Total & Recuento & 24442 & 27414 & 51856 \\
& $\%$ & $47,1 \%$ & $52,9 \%$ & $100,0 \%$ \\
\hline
\end{tabular}

Fuente: Elaboración propia a partir de la ESE 2012

Tabla de contingencia: Confianza en las instituciones: partidos políticos/Actitud hacia la inmigración

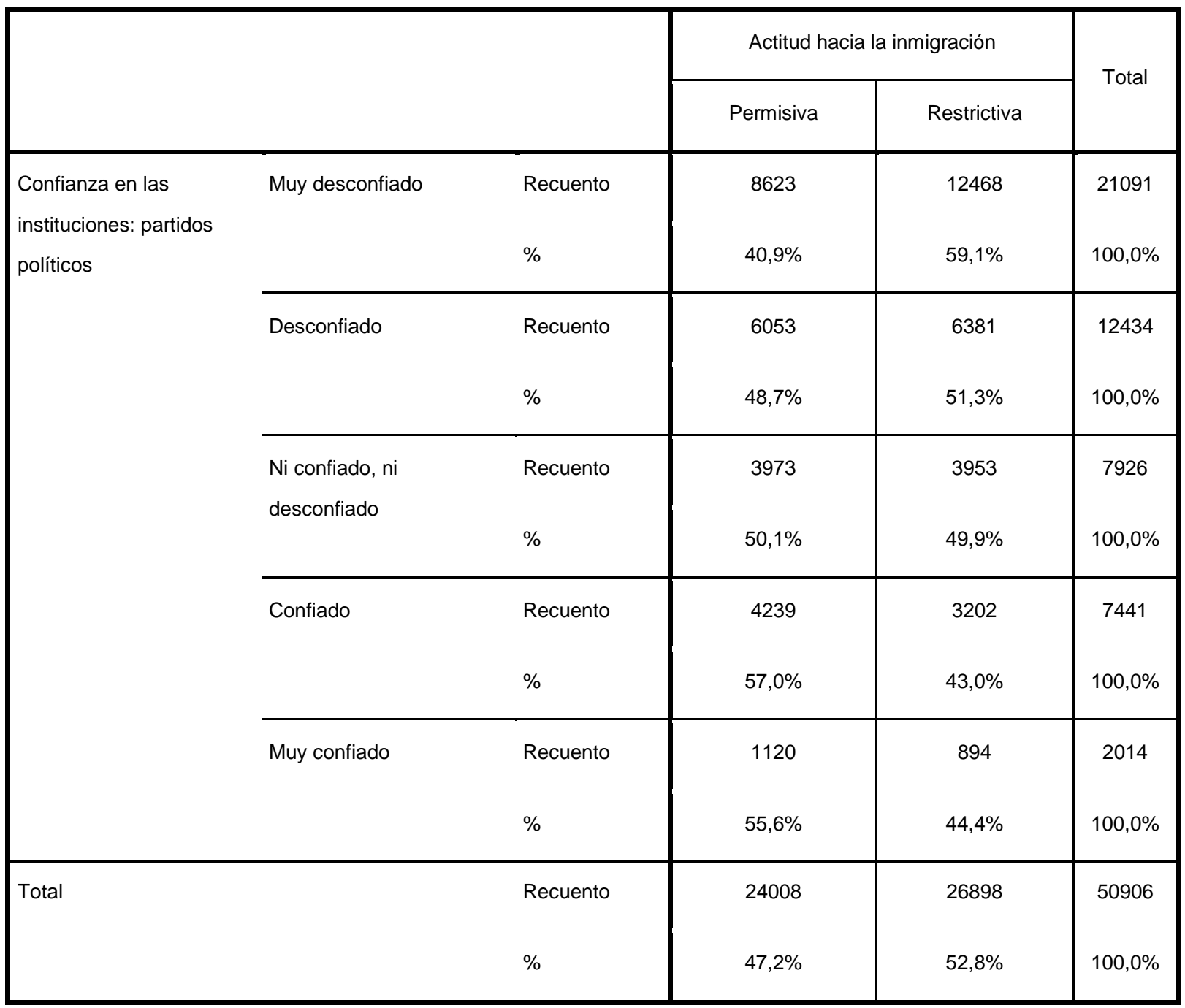

Fuente: Elaboración propia a partir de la ESE 2012 
Tabla de contingencia: Confianza en las instituciones: sistema judicial/Actitud hacia la

\section{inmigración}

\begin{tabular}{|c|c|c|c|c|c|}
\hline & & & \multicolumn{2}{|c|}{ Actitud hacia la inmigración } & \multirow{2}{*}{ Total } \\
\hline & & & Permisiva & Restrictiva & \\
\hline \multirow{10}{*}{$\begin{array}{l}\text { Confianza en las } \\
\text { instituciones: sistema } \\
\text { judicial }\end{array}$} & Muy desconfiado & Recuento & 4734 & 7511 & 12245 \\
\hline & & $\%$ & $38,7 \%$ & $61,3 \%$ & $100,0 \%$ \\
\hline & Desconfiado & Recuento & 4255 & 5444 & 9699 \\
\hline & & $\%$ & $43,9 \%$ & $56,1 \%$ & $100,0 \%$ \\
\hline & Ni confiado, ni desconfiado & Recuento & 3496 & 4045 & 7541 \\
\hline & & $\%$ & $46,4 \%$ & $53,6 \%$ & $100,0 \%$ \\
\hline & Confiado & Recuento & 5758 & 5212 & 10970 \\
\hline & & $\%$ & $52,5 \%$ & $47,5 \%$ & $100,0 \%$ \\
\hline & Muy confiado & Recuento & 5745 & 4606 & 10351 \\
\hline & & $\%$ & $55,5 \%$ & $44,5 \%$ & $100,0 \%$ \\
\hline \multirow[t]{2}{*}{ Total } & & Recuento & 23988 & 26818 & 50806 \\
\hline & & $\%$ & $47,2 \%$ & $52,8 \%$ & $100,0 \%$ \\
\hline
\end{tabular}

Fuente: Elaboración propia a partir de la ESE 2012

Tabla de contingencia: Protección de las minorías/Actitud hacia la inmigración

\begin{tabular}{|lcc|c|c|c|}
\hline & & \multicolumn{2}{|c|}{ Actitud hacia la inmigración } & \multirow{2}{*}{ Total } \\
\cline { 3 - 5 } & & Permisiva & Restrictiva & \\
\hline $\begin{array}{l}\text { Importante para la } \\
\text { democracia: que los } \\
\text { derechos de las minorías } \\
\text { estén protegidos }\end{array}$ & Nada importante & Recuento & 294 & 806 & 1100 \\
\cline { 2 - 5 } & Poco importante & Recuento & $26,7 \%$ & $73,3 \%$ & $100,0 \%$ \\
& & $\%$ & 576 & 1069 & 1645 \\
\hline
\end{tabular}




\begin{tabular}{|c|c|c|c|c|c|}
\hline & $\begin{array}{l}\text { Ni poco, ni muy } \\
\text { importante }\end{array}$ & $\begin{array}{l}\text { Recuento } \\
\%\end{array}$ & $\begin{array}{r}1022 \\
33,2 \%\end{array}$ & $\begin{array}{l}2053 \\
66,8 \%\end{array}$ & $\begin{array}{c}3075 \\
100,0 \%\end{array}$ \\
\hline & Bastante importante & $\begin{array}{l}\text { Recuento } \\
\%\end{array}$ & $\begin{array}{l}2994 \\
38,8 \%\end{array}$ & $\begin{array}{l}4725 \\
61,2 \%\end{array}$ & $\begin{array}{c}7719 \\
100,0 \%\end{array}$ \\
\hline & $\begin{array}{l}\text { Extremadamente } \\
\text { importante }\end{array}$ & $\begin{array}{l}\text { Recuento } \\
\%\end{array}$ & $\begin{array}{l}19058 \\
51,8 \%\end{array}$ & $\begin{array}{l}17713 \\
48,2 \%\end{array}$ & $\begin{array}{r}36771 \\
100,0 \%\end{array}$ \\
\hline Total & & $\begin{array}{l}\text { Recuento } \\
\%\end{array}$ & $\begin{array}{l}23944 \\
47,6 \%\end{array}$ & $\begin{array}{l}26366 \\
52,4 \%\end{array}$ & $\begin{array}{r}50310 \\
100,0 \%\end{array}$ \\
\hline
\end{tabular}

Fuente: Elaboración propia a partir de la ESE 2012

Tabla de contingencia: Actitud hacia personas de orientación homosexual/Actitud hacia la inmigración

\begin{tabular}{|c|c|c|c|c|c|}
\hline & & & \multicolumn{2}{|c|}{ Actitud hacia la inmigración } & \multirow{2}{*}{ Total } \\
\hline & & & Permisiva & Restrictiva & \\
\hline \multirow{9}{*}{$\begin{array}{l}\text { Gays y lesbianas deben de } \\
\text { ser libres para vivir como } \\
\text { quieran }\end{array}$} & Muy de acuerdo & Recuento & 9423 & 6047 & 15470 \\
\hline & De acuerdo & Recuento & 8160 & 8823 & 16983 \\
\hline & & $\%$ & $48,0 \%$ & $52,0 \%$ & $100,0 \%$ \\
\hline & $\begin{array}{l}\text { Ni de acuerdo, ni en } \\
\text { desacuerdo }\end{array}$ & Recuento & 2817 & 4449 & 7266 \\
\hline & & $\%$ & $38,8 \%$ & $61,2 \%$ & $100,0 \%$ \\
\hline & En desacuerdo & Recuento & 1689 & 3090 & 4779 \\
\hline & & $\%$ & $35,3 \%$ & $64,7 \%$ & $100,0 \%$ \\
\hline & Muy en desacuerdo & Recuento & 1532 & 3546 & 5078 \\
\hline & & $\%$ & $30,2 \%$ & $69,8 \%$ & $100,0 \%$ \\
\hline
\end{tabular}




\begin{tabular}{|c|c|c|c|c|}
\hline Total & Recuento & 23621 & 25955 & 49576 \\
\hline & $\%$ & $47,6 \%$ & $52,4 \%$ & $100,0 \%$ \\
\hline
\end{tabular}

Fuente: Elaboración propia a partir de la ESE 2012 
ANEXO 2.3.: TABLAS DE CONTINGENCIA VARIABLES: VALORACIÓN ACTUALIDAD POLÍTICA, SOCIAL Y ECONÓMICA / VARIABLE DEPENDIENTE: “ACTITUD HACIA LA INMIGRACIÓN PROCEDENTE DE PAÍSES POBRES DE FUERA DE LA UE"

Tabla de contingencia: Situación económica/Actitud hacia la inmigración

\begin{tabular}{|c|c|c|c|c|c|}
\hline & & & \multicolumn{2}{|c|}{ Actitud hacia la inmigración } & \multirow{2}{*}{ Total } \\
\hline & & & Permisiva & Restrictiva & \\
\hline \multirow{10}{*}{$\begin{array}{l}\text { Satisfacción con el estado } \\
\text { de la economía en su país }\end{array}$} & Muy insatisfecho & Recuento & 5976 & 9513 & 15489 \\
\hline & & $\%$ & $38,6 \%$ & $61,4 \%$ & $100,0 \%$ \\
\hline & Insatisfecho & Recuento & 5974 & 7014 & 12988 \\
\hline & & $\%$ & $46,0 \%$ & $54,0 \%$ & $100,0 \%$ \\
\hline & $\begin{array}{l}\text { Ni satisfecho, ni } \\
\text { insatisfecho }\end{array}$ & Recuento & 3361 & 3619 & 6980 \\
\hline & & $\%$ & $48,2 \%$ & $51,8 \%$ & $100,0 \%$ \\
\hline & Satisfecho & Recuento & 5728 & 4850 & 10578 \\
\hline & & $\%$ & $54,2 \%$ & $45,8 \%$ & $100,0 \%$ \\
\hline & Muy satisfecho & Recuento & 3105 & 2103 & 5208 \\
\hline & & $\%$ & $59,6 \%$ & $40,4 \%$ & $100,0 \%$ \\
\hline \multirow[t]{2}{*}{ Total } & & Recuento & 24144 & 27099 & 51243 \\
\hline & & $\%$ & $47,1 \%$ & $52,9 \%$ & $100,0 \%$ \\
\hline
\end{tabular}

Fuente: Elaboración propia a partir de la ESE 2012 
Tabla de contingencia: Labor del Gobierno/Actitud hacia la inmigración

\begin{tabular}{|c|c|c|c|c|c|}
\hline & & & \multicolumn{2}{|c|}{ Actitud hacia la inmigración } & \multirow{2}{*}{ Total } \\
\hline & & & Permisiva & Restrictiva & \\
\hline \multirow{10}{*}{$\begin{array}{l}\text { Satisfacción con la labor } \\
\text { del Gobierno de su país }\end{array}$} & Muy insatisfecho & Recuento & 6294 & 9380 & 15674 \\
\hline & & $\%$ & $40,2 \%$ & $59,8 \%$ & $100,0 \%$ \\
\hline & Insatisfecho & Recuento & 5449 & 6496 & 11945 \\
\hline & & $\%$ & $45,6 \%$ & $54,4 \%$ & $100,0 \%$ \\
\hline & $\begin{array}{l}\text { Ni satisfecho, ni } \\
\text { insatisfecho }\end{array}$ & Recuento & 3859 & 3951 & 7810 \\
\hline & & $\%$ & $49,4 \%$ & $50,6 \%$ & $100,0 \%$ \\
\hline & Satisfecho & Recuento & 5927 & 5004 & 10931 \\
\hline & & $\%$ & $54,2 \%$ & $45,8 \%$ & $100,0 \%$ \\
\hline & Muy satisfecho & Recuento & 2392 & 2058 & 4450 \\
\hline & & $\%$ & $53,8 \%$ & $46,2 \%$ & $100,0 \%$ \\
\hline \multirow[t]{2}{*}{ Total } & & Recuento & 23921 & 26889 & 50810 \\
\hline & & $\%$ & $47,1 \%$ & $52,9 \%$ & $100,0 \%$ \\
\hline
\end{tabular}

Fuente: Elaboración propia a partir de la ESE 2012

Tabla de contingencia: Funcionamiento de la democracia/Actitud hacia la inmigración

\begin{tabular}{|lcc|c|c|}
\hline & & \multicolumn{2}{|c|}{ Actitud hacia la inmigración } \\
\cline { 3 - 5 } & & Permisiva & Restrictiva \\
\hline $\begin{array}{l}\text { Satisfacción con el } \\
\text { funcionamiento de la } \\
\text { democracia en su país }\end{array}$ & Muy insatisfecho & Recuento & 3313 & 5134 \\
\cline { 2 - 5 } & Insatisfecho & Recuento & $39,2 \%$ & 8447 \\
& & $\%$ & 4222 & $50,8 \%$ \\
\end{tabular}




\begin{tabular}{|c|c|c|c|c|c|}
\hline & $\begin{array}{l}\text { Ni satisfecho, ni } \\
\text { insatisfecho }\end{array}$ & $\begin{array}{l}\text { Recuento } \\
\%\end{array}$ & $\begin{array}{r}3560 \\
43,5 \%\end{array}$ & $\begin{array}{l}4620 \\
56,5 \%\end{array}$ & $\begin{array}{c}8180 \\
100,0 \%\end{array}$ \\
\hline & Satisfecho & $\begin{array}{l}\text { Recuento } \\
\%\end{array}$ & $\begin{array}{r}6880 \\
50,7 \%\end{array}$ & $\begin{array}{r}6695 \\
49,3 \%\end{array}$ & $\begin{array}{c}13575 \\
100,0 \%\end{array}$ \\
\hline & Muy satisfecho & $\begin{array}{l}\text { Recuento } \\
\%\end{array}$ & $\begin{array}{l}5949 \\
56,7 \%\end{array}$ & $\begin{array}{r}4538 \\
43,3 \%\end{array}$ & $\begin{array}{c}10487 \\
100,0 \%\end{array}$ \\
\hline Total & & $\begin{array}{l}\text { Recuento } \\
\%\end{array}$ & $\begin{array}{l}23924 \\
47,5 \%\end{array}$ & $\begin{array}{l}26475 \\
52,5 \%\end{array}$ & $\begin{array}{c}50399 \\
100,0 \%\end{array}$ \\
\hline
\end{tabular}

Fuente: Elaboración propia a partir de la ESE 2012

Tabla de contingencia: Integración europea/Actitud hacia la inmigración

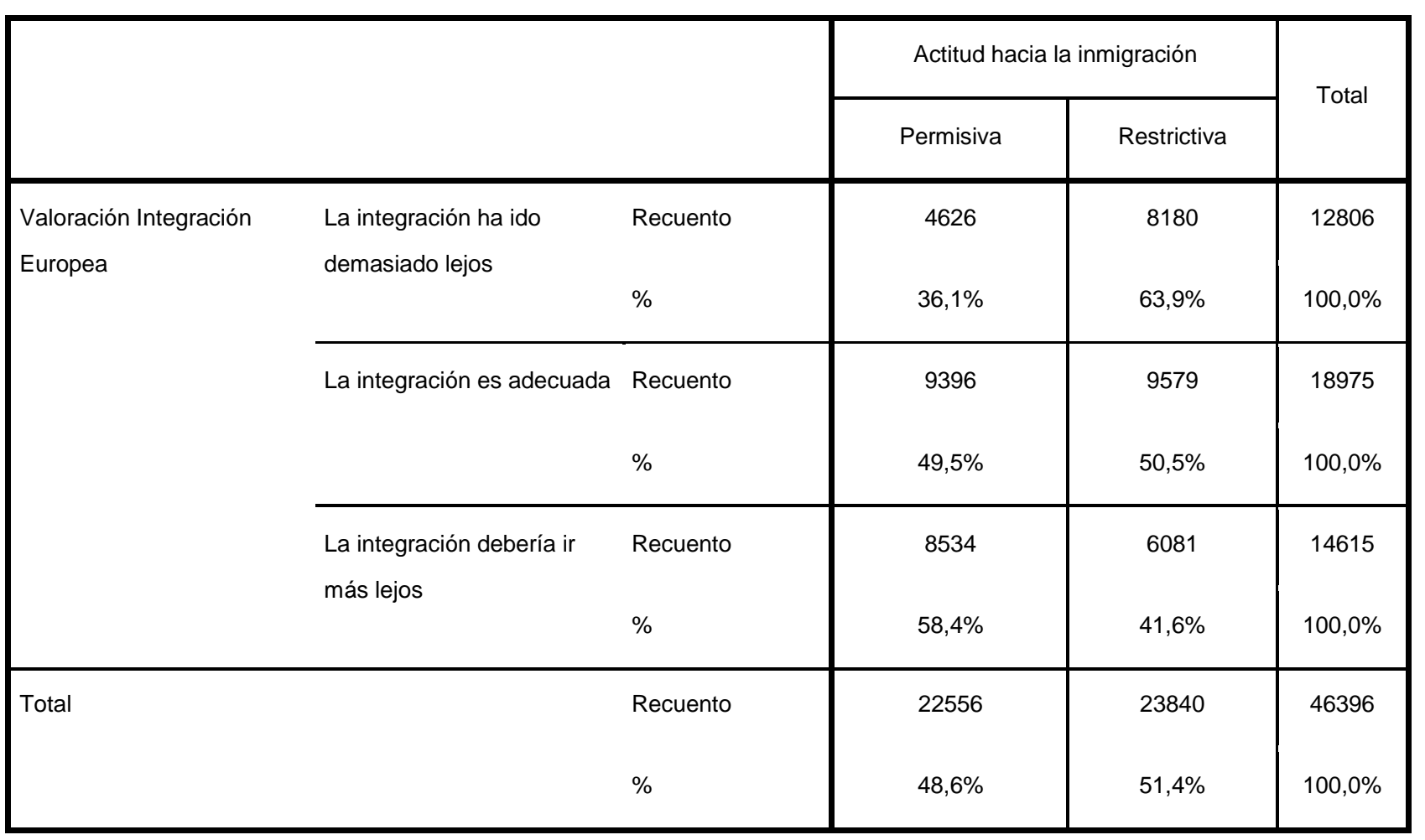

Fuente: Elaboración propia a partir de la ESE 2012 
Tabla de contingencia: Condiciones de vida/Actitud hacia la inmigración

\begin{tabular}{|c|c|c|c|c|c|}
\hline & & & \multicolumn{2}{|c|}{ Actitud hacia la inmigración } & \multirow{2}{*}{ Total } \\
\hline & & & Permisiva & Restrictiva & \\
\hline \multirow{9}{*}{$\begin{array}{l}\text { La vida de la mayoría de los } \\
\text { ciudadanos de su país está } \\
\text { yendo a peor }\end{array}$} & Muy de acuerdo & Recuento & 4721 & 7986 & 12707 \\
\hline & De acuerdo & Recuento & 9645 & 11162 & 20807 \\
\hline & & $\%$ & $46,4 \%$ & $53,6 \%$ & $100,0 \%$ \\
\hline & $\begin{array}{l}\text { Ni de acuerdo, ni en } \\
\text { desacuerdo }\end{array}$ & Recuento & 5176 & 4715 & 9891 \\
\hline & & $\%$ & $52,3 \%$ & $47,7 \%$ & $100,0 \%$ \\
\hline & En desacuerdo & Recuento & 4130 & 2932 & 7062 \\
\hline & & $\%$ & $58,5 \%$ & $41,5 \%$ & $100,0 \%$ \\
\hline & Muy en desacuerdo & Recuento & 506 & 389 & 895 \\
\hline & & $\%$ & $56,5 \%$ & $43,5 \%$ & $100,0 \%$ \\
\hline \multirow[t]{2}{*}{ Total } & & Recuento & 24178 & 27184 & 51362 \\
\hline & & $\%$ & $47,1 \%$ & $52,9 \%$ & $100,0 \%$ \\
\hline
\end{tabular}

Fuente: Elaboración propia a partir de la ESE 2012 
Tabla de contingencia: Seguridad de su barrio/Actitud hacia la inmigración

\begin{tabular}{|c|c|c|c|c|c|}
\hline & & & \multicolumn{2}{|c|}{ Actitud hacia la inmigración } & \multirow{2}{*}{ Total } \\
\hline & & & Permisiva & Restrictiva & \\
\hline \multirow{4}{*}{$\begin{array}{l}\text { Valoración seguridad de } \\
\text { su barrio }\end{array}$} & Es seguro o muy seguro & Recuento & 19349 & 19456 & 38805 \\
\hline & & $\%$ & $49,9 \%$ & $50,1 \%$ & $100,0 \%$ \\
\hline & $\begin{array}{l}\text { Es inseguro o muy } \\
\text { inseguro }\end{array}$ & Recuento & 4939 & 7720 & 12659 \\
\hline & & $\%$ & $39,0 \%$ & $61,0 \%$ & $100,0 \%$ \\
\hline \multirow[t]{2}{*}{ Total } & & Recuento & 24288 & 27176 & 51464 \\
\hline & & $\%$ & $47,2 \%$ & $52,8 \%$ & $100,0 \%$ \\
\hline
\end{tabular}

Fuente: Elaboración propia a partir de la ESE 2012 
ANEXO 3. TABLAS DE CONTROL POR TERCERAS VARIABLES

A) Control por edad:

Tabla de contingencia Edad/Ingresos/Actitud hacia la inmigración

\begin{tabular}{|c|c|c|c|c|c|c|}
\hline \multirow[b]{2}{*}{ Edad } & & & & \multicolumn{2}{|c|}{ Actitud hacia la inmigración } & \multirow{2}{*}{ Total } \\
\hline & & & & Permisiva & Restrictiva & \\
\hline \multirow[t]{10}{*}{ 15-29 } & Ingresos & Bajos & & 920 & 684 & 1604 \\
\hline & & & & $57,4 \%$ & $42,6 \%$ & $100,0 \%$ \\
\hline & & Medio-bajos & & 1252 & 1071 & 2323 \\
\hline & & & & $53,9 \%$ & $46,1 \%$ & $100,0 \%$ \\
\hline & & Medio-altos & & 1201 & 881 & 2082 \\
\hline & & & & $57,7 \%$ & $42,3 \%$ & $100,0 \%$ \\
\hline & & Altos & & 725 & 561 & 1286 \\
\hline & & & & $56,4 \%$ & $43,6 \%$ & $100,0 \%$ \\
\hline & Total & & Recuento & 4098 & 3197 & 7295 \\
\hline & & & $\%$ & $56,2 \%$ & $43,8 \%$ & $100,0 \%$ \\
\hline \multirow[t]{8}{*}{$30-44$} & Ingresos & Bajos & & 802 & 891 & 1693 \\
\hline & & & & $47,4 \%$ & $52,6 \%$ & $100,0 \%$ \\
\hline & & Medio-bajos & & 1517 & 1505 & 3022 \\
\hline & & & & $50,2 \%$ & $49,8 \%$ & $100,0 \%$ \\
\hline & & Medio-altos & & 1872 & 1663 & 3535 \\
\hline & & & & $53,0 \%$ & $47,0 \%$ & $100,0 \%$ \\
\hline & & Altos & & 1299 & 910 & 2209 \\
\hline & & & & $58,8 \%$ & $41,2 \%$ & $100,0 \%$ \\
\hline
\end{tabular}




\begin{tabular}{|c|c|c|c|c|c|c|}
\hline & \multicolumn{2}{|l|}{ Total } & \multirow{2}{*}{$\begin{array}{l}\text { Recuento } \\
\%\end{array}$} & \multirow{2}{*}{$\begin{array}{r}5490 \\
52,5 \%\end{array}$} & \multirow{2}{*}{$\begin{array}{r}4969 \\
47,5 \%\end{array}$} & \multirow{2}{*}{$\begin{array}{r}10459 \\
100,0 \%\end{array}$} \\
\hline & & & & & & \\
\hline \multirow[t]{10}{*}{$45-59$} & Ingresos & Bajos & & 898 & 1176 & 2074 \\
\hline & & & & $43,3 \%$ & $56,7 \%$ & $100,0 \%$ \\
\hline & & Medio-bajos & & 1496 & 1809 & 3305 \\
\hline & & & & $45,3 \%$ & $54,7 \%$ & $100,0 \%$ \\
\hline & & Medio-altos & & 1717 & 1754 & 3471 \\
\hline & & & & $49,5 \%$ & $50,5 \%$ & $100,0 \%$ \\
\hline & & Altos & & 1222 & 970 & 2192 \\
\hline & & & & $55,7 \%$ & $44,3 \%$ & $100,0 \%$ \\
\hline & Total & & Recuento & 5333 & 5709 & 11042 \\
\hline & & & $\%$ & $48,3 \%$ & $51,7 \%$ & $100,0 \%$ \\
\hline \multirow[t]{10}{*}{$>60$} & Ingresos & Recuento & & 1496 & 2742 & 4238 \\
\hline & & & & $35,3 \%$ & $64,7 \%$ & $100,0 \%$ \\
\hline & & Recuento & & 2013 & 3147 & 5160 \\
\hline & & & & $39,0 \%$ & $61,0 \%$ & $100,0 \%$ \\
\hline & & Medio-altos & & 1251 & 1497 & 2748 \\
\hline & & & & $45,5 \%$ & $54,5 \%$ & $100,0 \%$ \\
\hline & & Altos & & 572 & 522 & 1094 \\
\hline & & & & $52,3 \%$ & $47,7 \%$ & $100,0 \%$ \\
\hline & Total & & Recuento & 5332 & 7908 & 13240 \\
\hline & & & $\%$ & $40,3 \%$ & $59,7 \%$ & $100,0 \%$ \\
\hline \multirow[t]{3}{*}{ Total } & Ingresos & Bajos & & 4116 & 5493 & 9609 \\
\hline & & & & $42,8 \%$ & $57,2 \%$ & $100,0 \%$ \\
\hline & & Medio-bajos & & 6278 & 7532 & 13810 \\
\hline
\end{tabular}




\begin{tabular}{|c|c|c|c|c|} 
& & $45,5 \%$ & $54,5 \%$ & $100,0 \%$ \\
\cline { 2 - 5 } & & 6041 & 5795 & 11836 \\
& & $51,0 \%$ & $49,0 \%$ & $100,0 \%$ \\
\hline & & 3818 & 2963 & 6781 \\
\hline & & $56,3 \%$ & $43,7 \%$ & $100,0 \%$ \\
\hline & Redio-altos & 20253 & 21783 & 42036 \\
& $\%$ & $48,2 \%$ & $51,8 \%$ & $100,0 \%$ \\
\hline
\end{tabular}

\begin{tabular}{|lcccc|}
\hline \multicolumn{4}{c}{ Pruebas de Chi-cuadrado } & \\
Edad & Valor & gl & \multicolumn{2}{c|}{ Sig. asintótica (2 } \\
caras) \\
$15-29$ & $7,761^{\mathrm{b}}$ & 3 &, 051 \\
$30-44$ & $59,781^{\mathrm{C}}$ & 3 &, 000 \\
$45-59$ & $83,565^{\mathrm{d}}$ & 3 &, 000 \\
$>60$ & $144,120^{\mathrm{e}}$ & 3 &, 000 \\
Total & $368,915^{\mathrm{a}}$ & 3 &, 000 \\
\hline
\end{tabular}

Fuente: elaboración propia a partir de la ESE 2012 
B) Control por nivel educativo:

Tabla de contingencia Nivel de estudios/Edad/Actitud hacia la inmigración

\begin{tabular}{|c|c|c|c|c|c|c|}
\hline \multirow[b]{2}{*}{ Nivel de estudios } & & & & \multicolumn{2}{|c|}{ Actitud hacia la inmigración } & \multirow[b]{2}{*}{ Total } \\
\hline & & & & Permisiva & Restrictiva & \\
\hline \multirow{9}{*}{$\begin{array}{l}\text { Estudios primarios o sin } \\
\text { estudios }\end{array}$} & Edad & $15-29$ & & 291 & 254 & 545 \\
\hline & & $30-44$ & & 346 & 432 & 778 \\
\hline & & & & $44,5 \%$ & $55,5 \%$ & $100,0 \%$ \\
\hline & & $45-59$ & & 541 & 820 & 1361 \\
\hline & & & & $39,8 \%$ & $60,2 \%$ & $100,0 \%$ \\
\hline & & $>60$ & & 1411 & 3048 & 4459 \\
\hline & & & & $31,6 \%$ & $68,4 \%$ & $100,0 \%$ \\
\hline & Total & & Recuento & 2589 & 4554 & 7143 \\
\hline & & & $\%$ & $36,2 \%$ & $63,8 \%$ & $100,0 \%$ \\
\hline \multirow[t]{9}{*}{ Estudios secundarios } & Edad & $15-29$ & & 3590 & 3067 & 6657 \\
\hline & & & & $53,9 \%$ & $46,1 \%$ & $100,0 \%$ \\
\hline & & $30-44$ & & 2879 & 3546 & 6425 \\
\hline & & & & $44,8 \%$ & $55,2 \%$ & $100,0 \%$ \\
\hline & & $45-59$ & & 3375 & 4470 & 7845 \\
\hline & & & & $43,0 \%$ & $57,0 \%$ & $100,0 \%$ \\
\hline & & $>60$ & & 3105 & 4898 & 8003 \\
\hline & & & & $38,8 \%$ & $61,2 \%$ & $100,0 \%$ \\
\hline & Total & & Recuento & 12949 & 15981 & 28930 \\
\hline
\end{tabular}




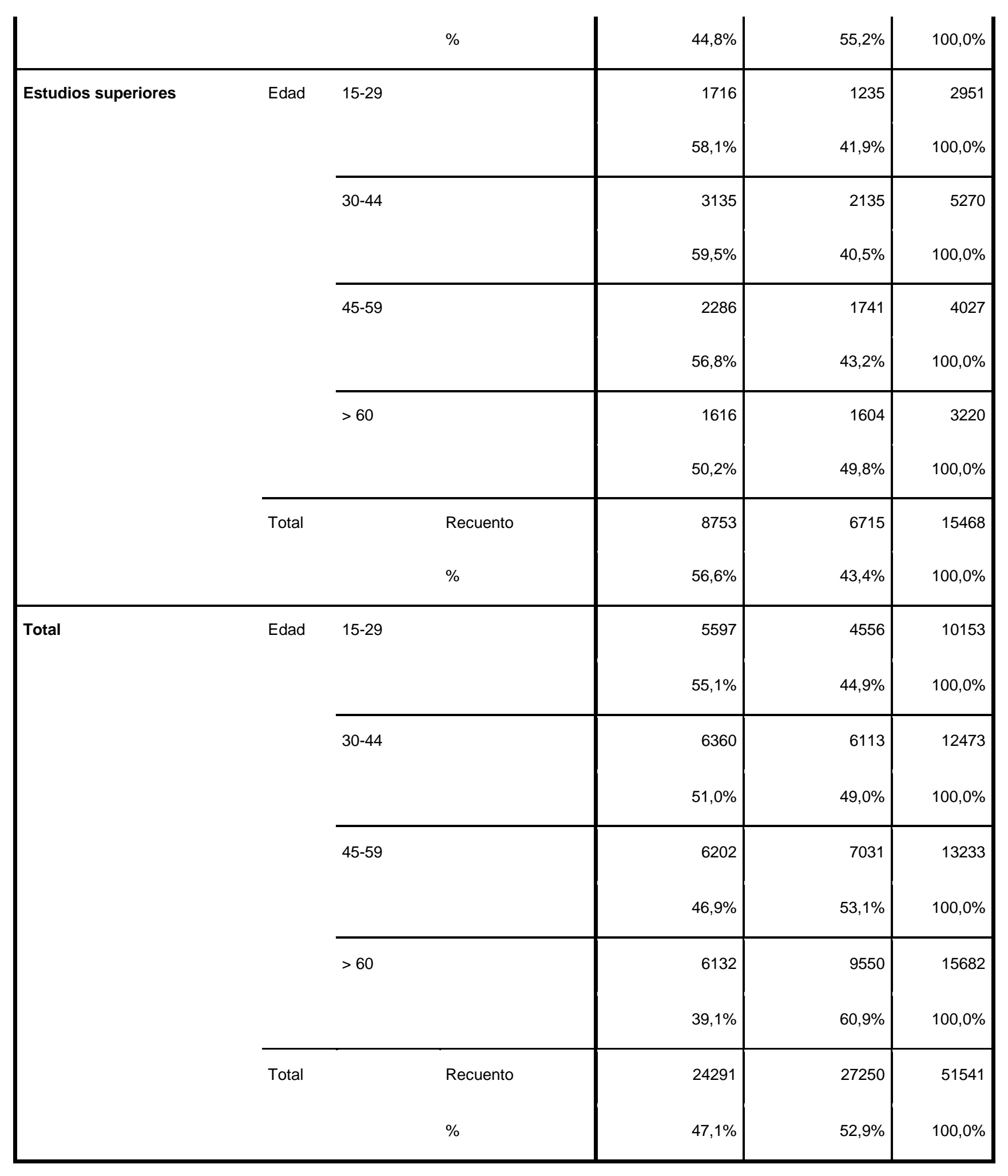

\begin{tabular}{|c|c|c|c|}
\hline \multicolumn{4}{|c|}{ Pruebas de Chi-cuadrado } \\
\hline Nivel de estudios & Valor & $\mathrm{gl}$ & (2 caras) \\
\hline
\end{tabular}




\begin{tabular}{|lccc|}
\hline $\begin{array}{l}\text { Estudios primarios o sin } \\
\text { estudios }\end{array}$ & $140,245^{\mathrm{b}}$ & 3 &, 000 \\
Estudios secundarios & $350,964^{\mathrm{c}}$ & 3 &, 000 \\
Estudios superiores & $74,736^{\mathrm{d}}$ & 3 &, 000 \\
Total & $741,102^{\mathrm{a}}$ & 3 &, 000 \\
\hline
\end{tabular}

Fuente: elaboración propia a partir de la ESE 2012

Tabla de contingencia Nivel de estudios/Ingresos/Actitud hacia la inmigración

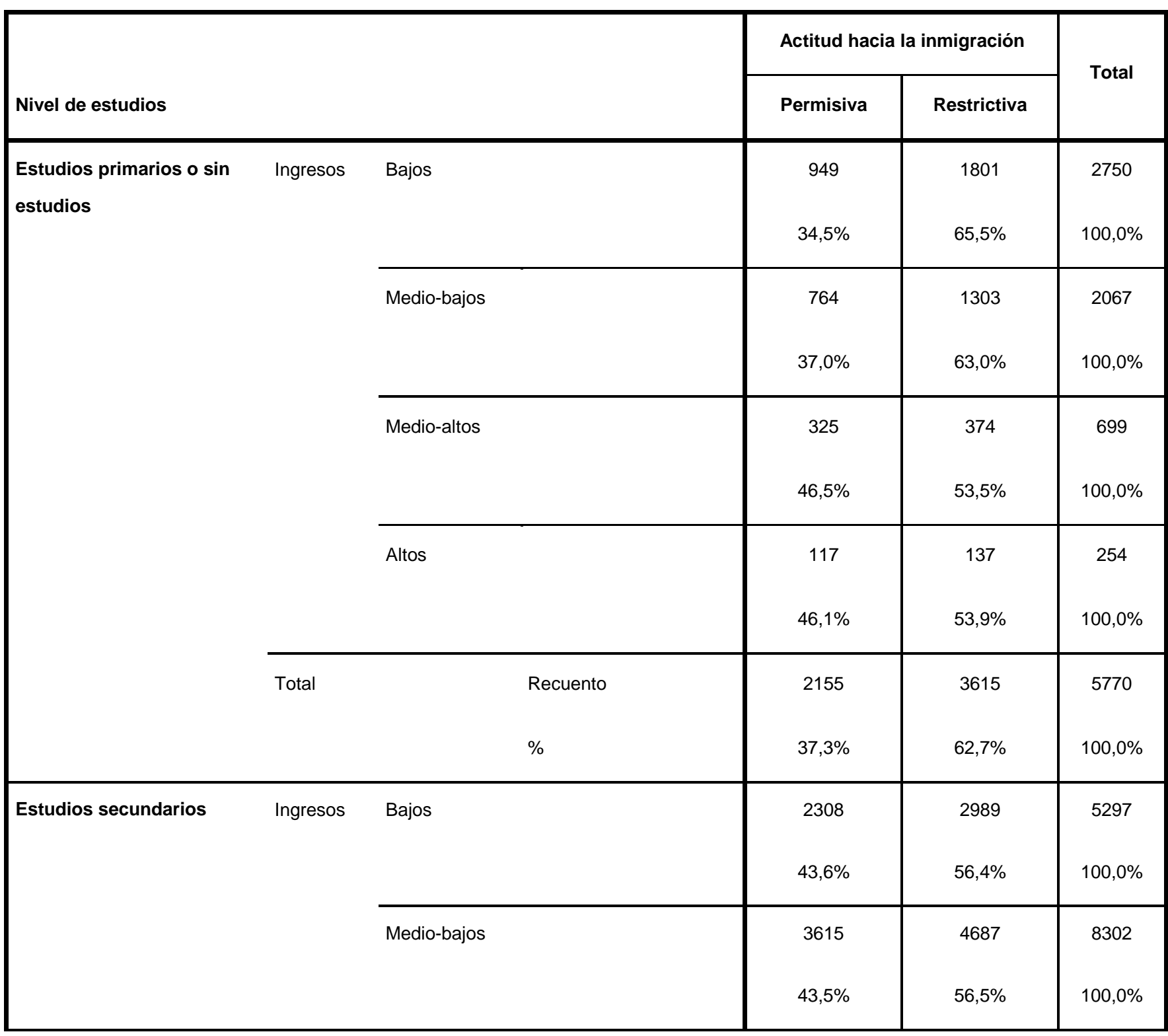




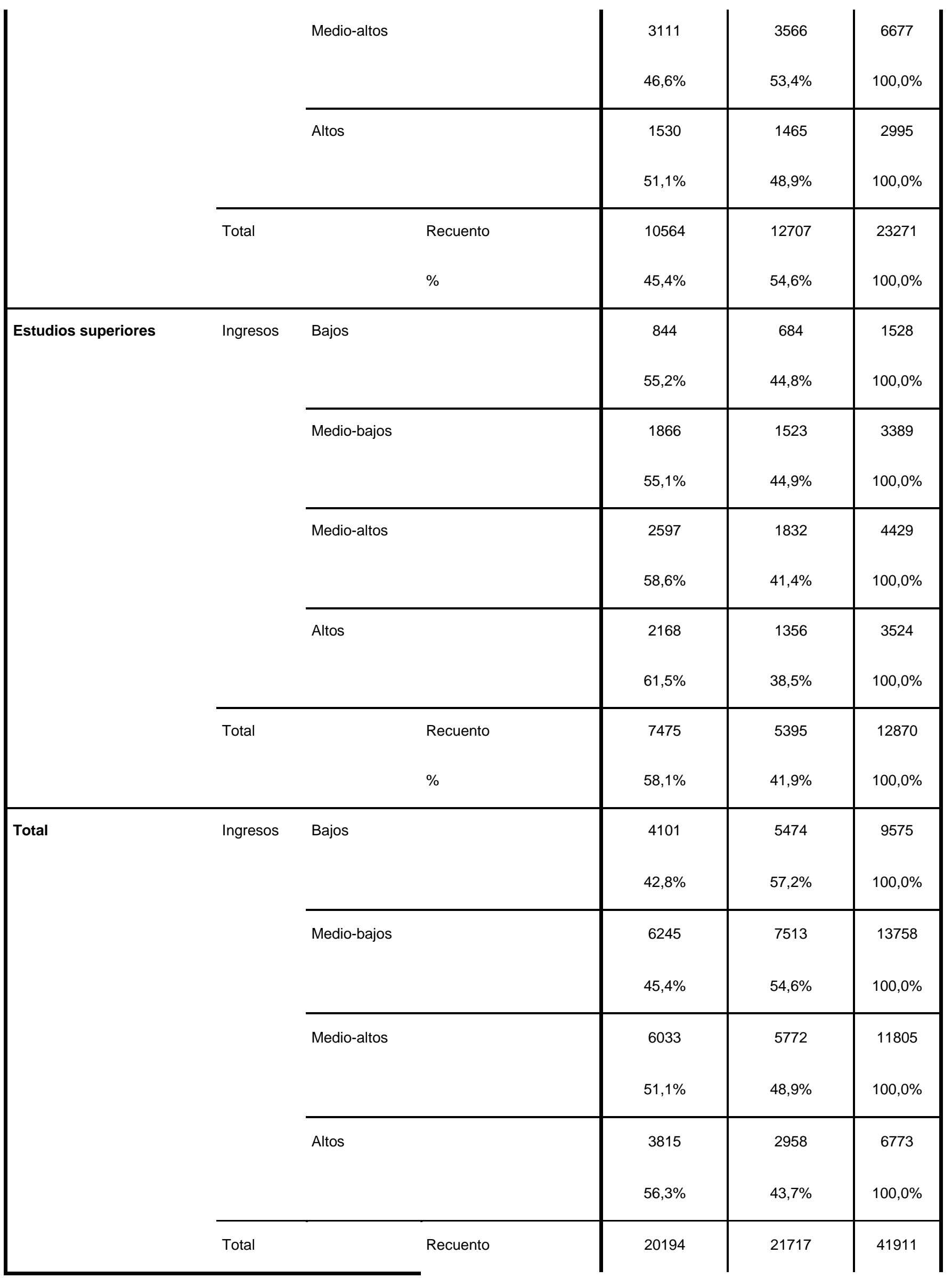




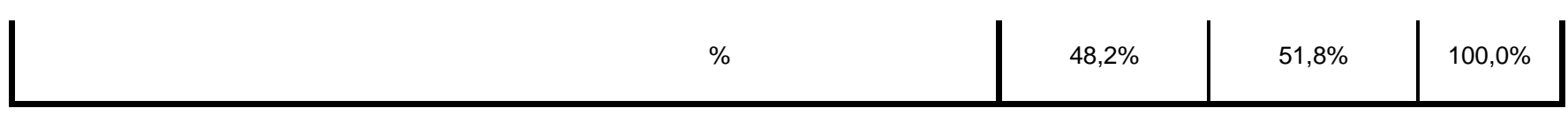

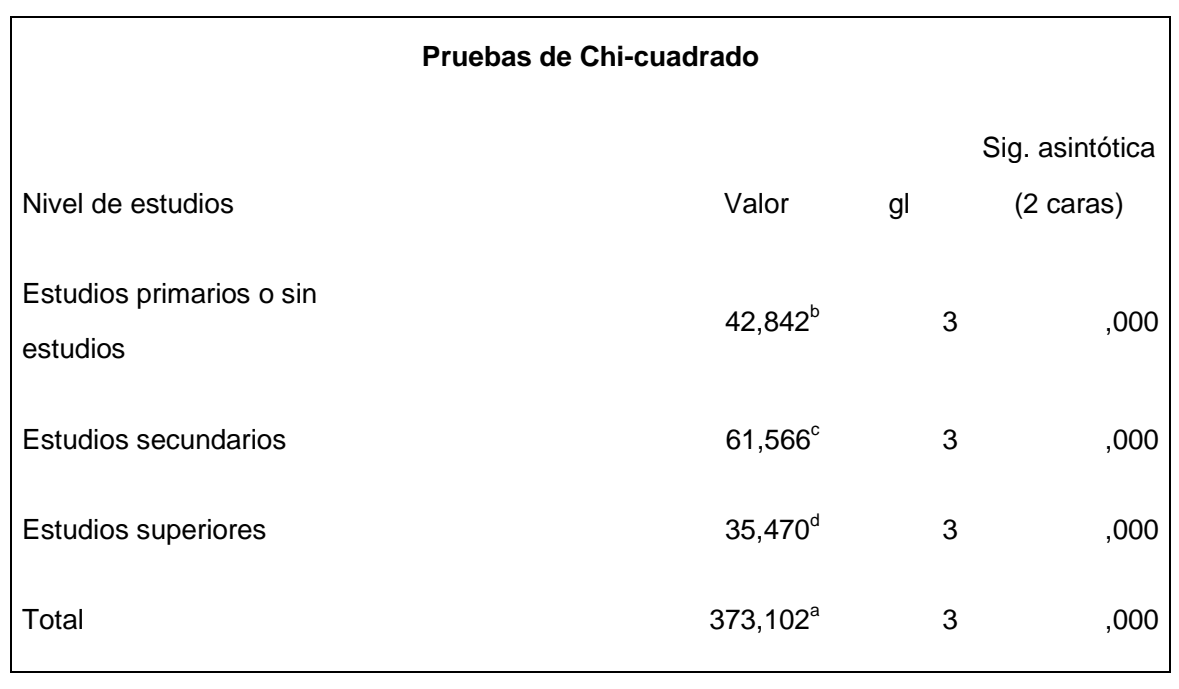

Fuente: elaboración propia a partir de la ESE 2012 


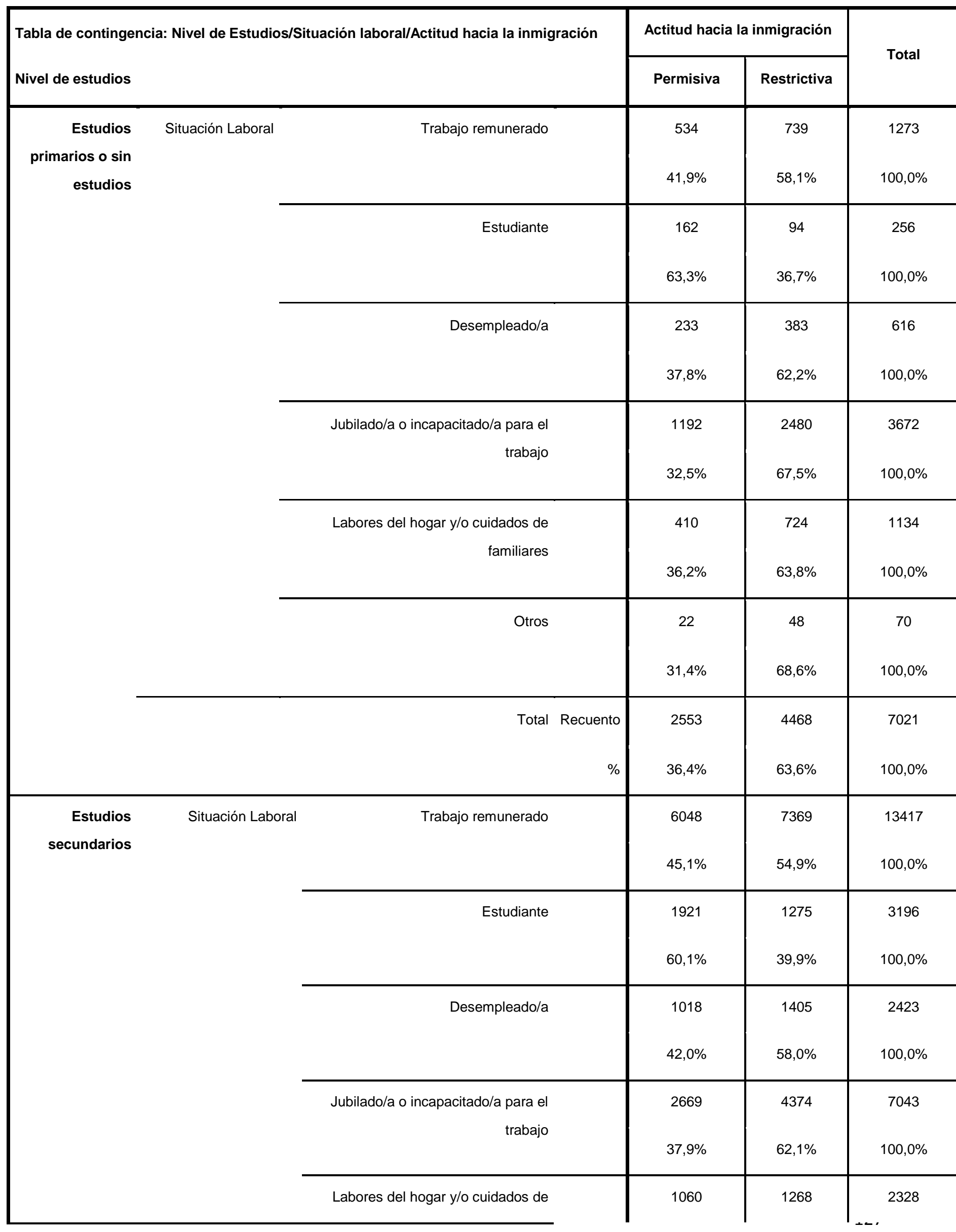




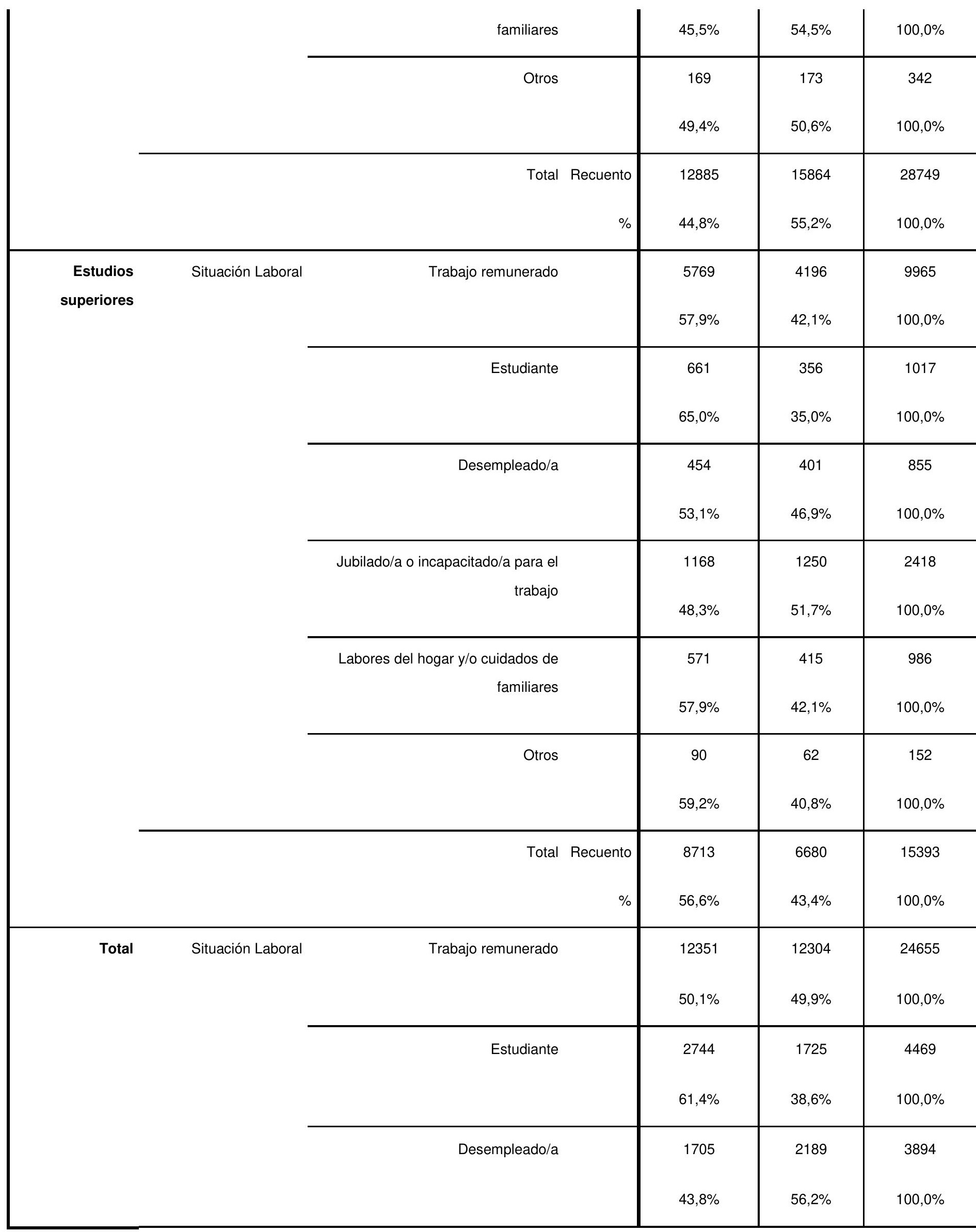




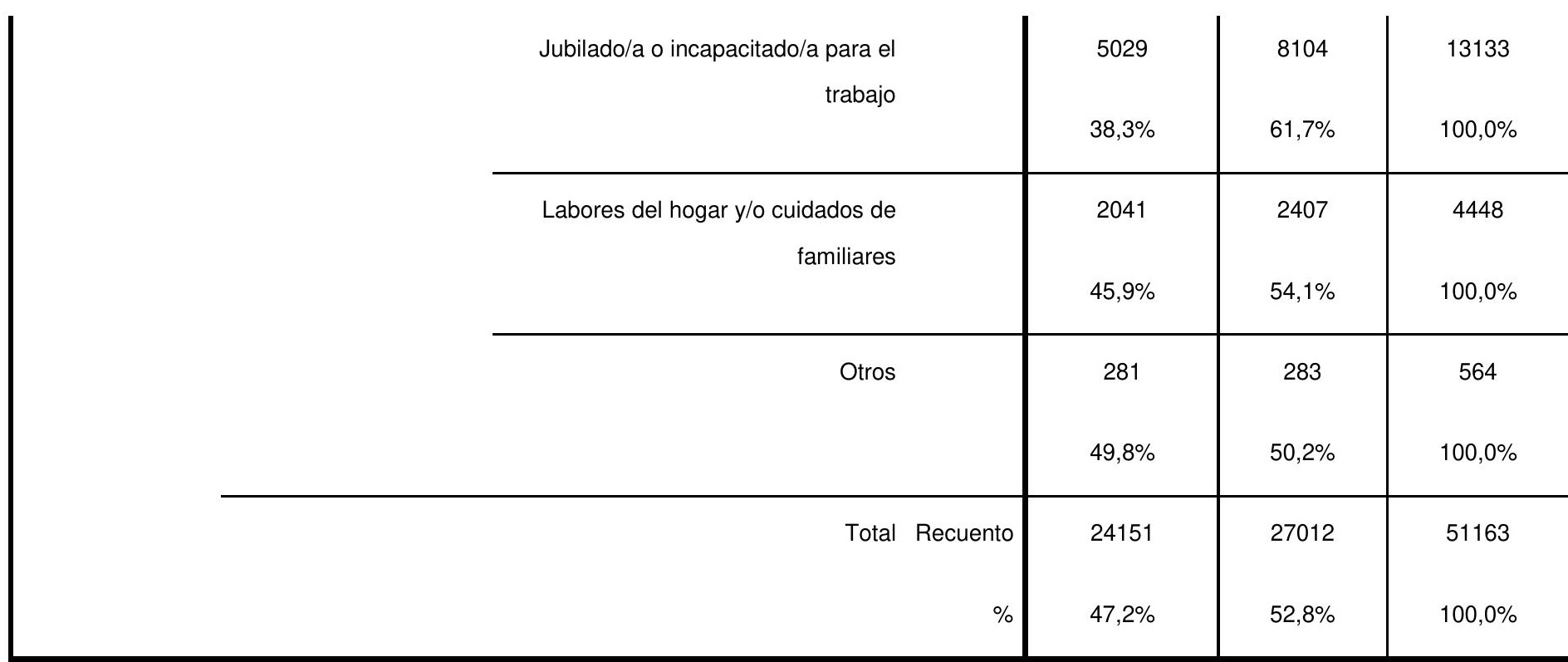

\begin{tabular}{|lccc|}
\hline & Pruebas de chi-cuadrado & & \\
Nivel de estudios & Valor & gl & Sig. asintótica \\
(2 caras) \\
Estudios primarios o sin & & & \\
estudios & $122,799^{\mathrm{b}}$ & 5 &, 000 \\
Estudios secundarios & & 5 &, 000 \\
Estudios superiores & $449,977^{\mathrm{c}}$ & 500 &, 000 \\
Total & $109,076^{\mathrm{d}}$ & 5 &, 000 \\
\hline
\end{tabular}

Fuente: elaboración propia a partir de la ESE 2012 
C) Control por ingresos:

Tabla de contingencia Ingresos/Situación laboral/Actitud hacia la inmigración

\begin{tabular}{|c|c|c|c|c|c|c|}
\hline \multirow{2}{*}{ Ingresos } & & & & \multicolumn{2}{|c|}{ Actitud hacia la inmigración } & \multirow{2}{*}{ Total } \\
\hline & & & & Permisiva & Restrictiva & \\
\hline \multirow{7}{*}{ Bajos } & \multirow{6}{*}{ Situación Laboral } & Trabajo remunerado & & $\begin{array}{l}1015 \\
50,2 \%\end{array}$ & $\begin{array}{r}1005 \\
49,8 \%\end{array}$ & $\begin{array}{c}2020 \\
100,0 \%\end{array}$ \\
\hline & & Estudiante & & $\begin{array}{c}477 \\
65,5 \%\end{array}$ & $\begin{array}{c}251 \\
34,5 \%\end{array}$ & $\begin{array}{c}728 \\
100,0 \%\end{array}$ \\
\hline & & Desempleado/a & & $\begin{array}{c}649 \\
41,8 \%\end{array}$ & $\begin{array}{c}904 \\
58,2 \%\end{array}$ & $\begin{array}{c}1553 \\
100,0 \%\end{array}$ \\
\hline & & $\begin{array}{l}\text { Jubilado/a o } \\
\text { incapacitado/a para el } \\
\text { trabajo }\end{array}$ & & $\begin{array}{l}1373 \\
35,5 \%\end{array}$ & $\begin{array}{l}2492 \\
64,5 \%\end{array}$ & $\begin{array}{c}3865 \\
100,0 \%\end{array}$ \\
\hline & & $\begin{array}{l}\text { Labores del hogar y/o } \\
\text { cuidados de familiares }\end{array}$ & & $\begin{array}{r}506 \\
41,9 \%\end{array}$ & $\begin{array}{c}702 \\
58,1 \%\end{array}$ & $\begin{array}{c}1208 \\
100,0 \%\end{array}$ \\
\hline & & Otros & & $\begin{array}{c}58 \\
50,9 \%\end{array}$ & $\begin{array}{c}56 \\
49,1 \%\end{array}$ & $\begin{array}{c}114 \\
100,0 \%\end{array}$ \\
\hline & Total & & $\begin{array}{l}\text { Recuento } \\
\%\end{array}$ & $\begin{array}{r}4078 \\
43,0 \%\end{array}$ & $\begin{array}{l}5410 \\
57,0 \%\end{array}$ & $\begin{array}{c}9488 \\
100,0 \%\end{array}$ \\
\hline \multirow{4}{*}{ Medio-bajos } & \multirow{4}{*}{ Situación Laboral } & Trabajo remunerado & & $\begin{array}{l}2906 \\
48,7 \%\end{array}$ & $\begin{array}{r}3058 \\
51,3 \%\end{array}$ & $\begin{array}{c}5964 \\
100,0 \%\end{array}$ \\
\hline & & Estudiante & & $\begin{array}{c}519 \\
60,1 \%\end{array}$ & $\begin{array}{c}345 \\
39,9 \%\end{array}$ & $\begin{array}{c}864 \\
100,0 \%\end{array}$ \\
\hline & & Desempleado/a & & $\begin{array}{c}485 \\
46,4 \%\end{array}$ & $\begin{array}{c}561 \\
53,6 \%\end{array}$ & $\begin{array}{c}1046 \\
100,0 \%\end{array}$ \\
\hline & & Jubilado/a o & & 1743 & 2743 & 4486 \\
\hline
\end{tabular}




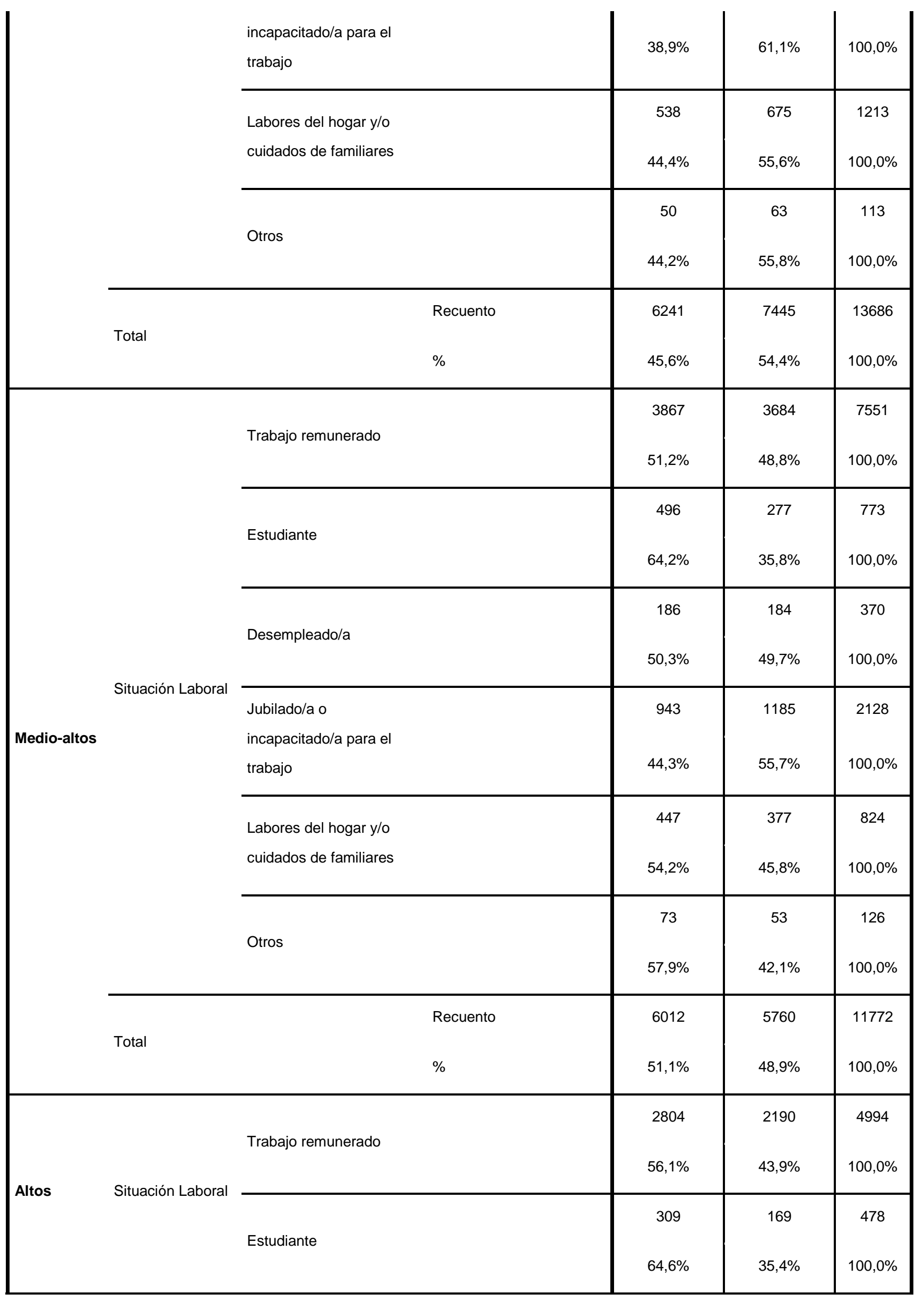




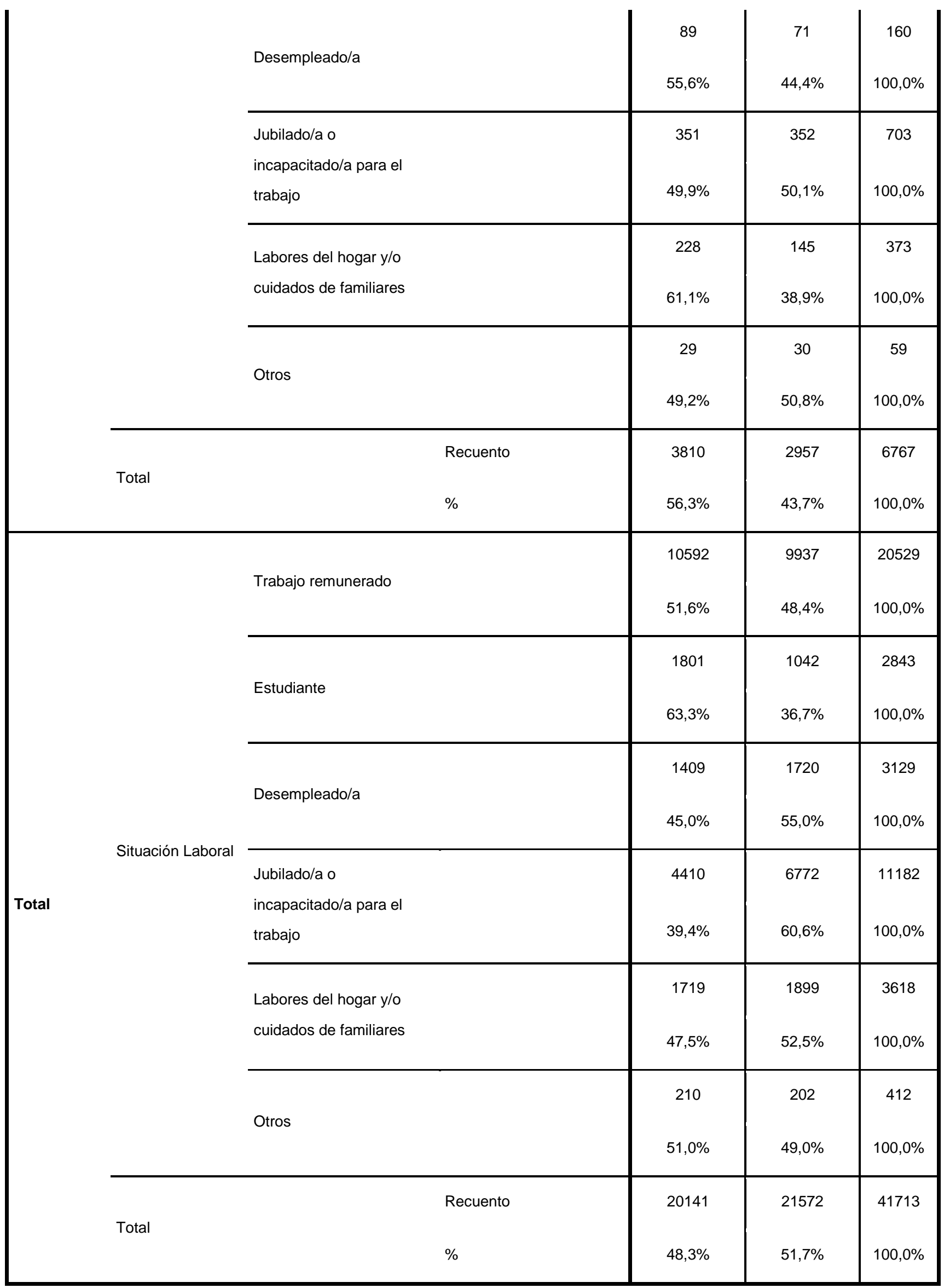

Fuente: elaboración propia a partir de la ESE 2012 
D) Nivel de estudios e ingresos: ocupación

Media de años de estudios completados por categoría ocupacional

\begin{tabular}{|c|c|c|c|}
\hline Ocupación & Media & $\mathrm{N}$ & $\begin{array}{l}\text { Desviación } \\
\text { estándar }\end{array}$ \\
\hline Ocupaciones militares & 13,79 & 179 & 3,454 \\
\hline Gerentes & 14,77 & 3349 & 3,738 \\
\hline Profesionales & 16,37 & 8132 & 3,494 \\
\hline $\begin{array}{l}\text { Técnicos y profesionales de } \\
\text { nivel medio }\end{array}$ & 13,83 & 6590 & 3,430 \\
\hline $\begin{array}{l}\text { Personal de apoyo } \\
\text { administrativo }\end{array}$ & 12,87 & 4123 & 3,204 \\
\hline $\begin{array}{l}\text { Trabajadores de los servicios y } \\
\text { de ventas }\end{array}$ & 12,05 & 8994 & 3,287 \\
\hline $\begin{array}{l}\text { Trabajadores expertos en } \\
\text { agricultura, pesca y forestal }\end{array}$ & 9,39 & 1358 & 3,941 \\
\hline Artesanía y otros oficios & 11,17 & 5732 & 3,164 \\
\hline $\begin{array}{l}\text { Operadores de instalaciones y } \\
\text { máquinas }\end{array}$ & 10,62 & 4178 & 3,162 \\
\hline Ocupaciones elementales & 10,03 & 5363 & 3,439 \\
\hline Total & 12,76 & 47998 & 4,004 \\
\hline
\end{tabular}

Fuente: elaboración propia a partir de la ESE 2012 
Mediana de ingresos por categoría ocupacional

\begin{tabular}{|c|c|c|c|}
\hline Ocupación & $\mathrm{N}$ & $\begin{array}{l}\text { Desviación } \\
\text { estándar }\end{array}$ & Mediana \\
\hline Ocupaciones militares & 141 & 2,740 & 7,00 \\
\hline Gerentes & 2786 & 2,820 & 7,00 \\
\hline Profesionales & 6856 & 2,670 & 7,00 \\
\hline $\begin{array}{l}\text { Técnicos y profesionales de } \\
\text { nivel medio }\end{array}$ & 5627 & 2,687 & 6,00 \\
\hline $\begin{array}{l}\text { Personal de apoyo } \\
\text { administrativo }\end{array}$ & 3324 & 2,641 & 5,00 \\
\hline $\begin{array}{l}\text { Trabajadores de los servicios y } \\
\text { de ventas }\end{array}$ & 7235 & 2,707 & 4,00 \\
\hline $\begin{array}{l}\text { Trabajadores expertos en } \\
\text { agricultura, pesca y forestal }\end{array}$ & 1099 & 2,607 & 3,00 \\
\hline Artesanía y otros oficios & 4832 & 2,644 & 4,00 \\
\hline $\begin{array}{l}\text { Operadores de instalaciones y } \\
\text { máquinas }\end{array}$ & 3510 & 2,594 & 4,00 \\
\hline Ocupaciones elementales & 4431 & 2,499 & 3,00 \\
\hline Total & 39841 & 2,814 & 5,00 \\
\hline
\end{tabular}

Fuente: elaboración propia a partir de la ESE 2012 
ANEXO 4: ACTITUDES HACIA LA INMIGRACIÓN POR PAÍSES

\begin{tabular}{|c|c|c|c|c|}
\hline ALEMANIA & $\begin{array}{l}\text { Permisiva } \\
\text { Restrictiva } \\
\text { Válido } \\
\text { Perdidos } \\
\mathrm{N} \text { total }\end{array}$ & $\begin{array}{l}\text { Frecuencia } \\
1963 \\
962 \\
2925 \\
33 \\
2958 \\
\end{array}$ & $\begin{array}{l}\text { Porcentaje } \\
66,4 \\
32,5 \\
98,9 \\
1,1 \\
100 \\
\end{array}$ & $\begin{array}{l}\text { Porcentaje } \\
\text { válido } \\
67,1 \\
32,9 \\
100\end{array}$ \\
\hline BÉLGICA & $\begin{array}{l}\text { Permisiva } \\
\text { Restrictiva } \\
\text { Válido } \\
\text { Perdidos } \\
\mathrm{N} \text { total }\end{array}$ & $\begin{array}{l}\text { Frecuencia } \\
1042 \\
823 \\
1865 \\
4 \\
1869 \\
\end{array}$ & $\begin{array}{l}\text { Porcentaje } \\
55,8 \\
44 \\
99,8 \\
0,2 \\
100 \\
\end{array}$ & $\begin{array}{l}\text { Porcentaje } \\
\text { válido } \\
55,9 \\
44,1 \\
100\end{array}$ \\
\hline DINAMARCA & $\begin{array}{l}\text { Permisiva } \\
\text { Restrictiva } \\
\text { Válido } \\
\text { Perdidos } \\
\mathrm{N} \text { total }\end{array}$ & $\begin{array}{l}\text { Frecuencia } \\
786 \\
814 \\
1600 \\
50 \\
1650\end{array}$ & $\begin{array}{l}\text { Porcentaje } \\
47,6 \\
49,3 \\
97 \\
3 \\
100\end{array}$ & $\begin{array}{l}\text { Porcentaje } \\
\text { válido } \\
49,1 \\
50,9 \\
100\end{array}$ \\
\hline ESPAÑA & $\begin{array}{l}\text { Permisiva } \\
\text { Restrictiva } \\
\text { Válido } \\
\text { Perdidos } \\
\mathrm{N} \text { total }\end{array}$ & $\begin{array}{l}\text { Frecuencia } \\
1010 \\
806 \\
1816 \\
73 \\
1889 \\
\end{array}$ & $\begin{array}{l}\text { Porcentaje } \\
53,5 \\
42,7 \\
96,1 \\
3,9 \\
100 \\
\end{array}$ & $\begin{array}{l}\text { Porcentaje } \\
\text { válido } \\
55,6 \\
44,4 \\
100\end{array}$ \\
\hline FINLANDIA & $\begin{array}{l}\text { Permisiva } \\
\text { Restrictiva } \\
\text { Válido } \\
\text { Perdidos } \\
\mathrm{N} \text { total }\end{array}$ & $\begin{array}{l}\text { Frecuencia } \\
806 \\
1357 \\
2163 \\
34 \\
2197 \\
\end{array}$ & $\begin{array}{l}\text { Porcentaje } \\
36,7 \\
61,8 \\
98,5 \\
1,5 \\
100 \\
\end{array}$ & $\begin{array}{l}\text { Porcentaje } \\
\text { válido } \\
37,3 \\
62,7 \\
100\end{array}$ \\
\hline FRANCIA & $\begin{array}{l}\text { Permisiva } \\
\text { Restrictiva } \\
\text { Válido } \\
\text { Perdidos } \\
\mathrm{N} \text { total }\end{array}$ & $\begin{array}{l}\text { Frecuencia } \\
1034 \\
910 \\
1944 \\
24 \\
1968 \\
\end{array}$ & $\begin{array}{l}\text { Porcentaje } \\
52,5 \\
46,2 \\
98,8 \\
1,2 \\
100 \\
\end{array}$ & $\begin{array}{l}\text { Porcentaje } \\
\text { válido } \\
53,2 \\
46,8 \\
100\end{array}$ \\
\hline IRLANDA & $\begin{array}{l}\text { Permisiva } \\
\text { Restrictiva } \\
\text { Válido }\end{array}$ & $\begin{array}{l}\text { Frecuencia } \\
1311 \\
1273 \\
2584 \\
\end{array}$ & $\begin{array}{l}\text { Porcentaje } \\
49,9 \\
48,4 \\
98,3\end{array}$ & $\begin{array}{l}\text { Porcentaje } \\
\text { válido } \\
50,7 \\
49,3 \\
100\end{array}$ \\
\hline
\end{tabular}




\begin{tabular}{|c|c|c|c|c|}
\hline & $\begin{array}{l}\text { Perdidos } \\
\mathrm{N} \text { total }\end{array}$ & $\begin{array}{l}44 \\
2628\end{array}$ & $\begin{array}{l}1,7 \\
100\end{array}$ & \\
\hline ISLANDIA & $\begin{array}{l}\text { Permisiva } \\
\text { Restrictiva } \\
\text { Válido } \\
\text { Perdidos } \\
\mathrm{N} \text { total }\end{array}$ & $\begin{array}{l}\text { Frecuencia } \\
545 \\
178 \\
723 \\
29 \\
752\end{array}$ & $\begin{array}{l}\text { Porcentaje } \\
72,5 \\
23,7 \\
96,1 \\
3,9 \\
100\end{array}$ & $\begin{array}{l}\text { Porcentaje } \\
\text { válido } \\
75,4 \\
24,6 \\
100\end{array}$ \\
\hline ITALIA & $\begin{array}{l}\text { Permisiva } \\
\text { Restrictiva } \\
\text { Válido } \\
\text { Perdidos } \\
\mathrm{N} \text { total }\end{array}$ & $\begin{array}{l}\text { Frecuencia } \\
603 \\
330 \\
933 \\
27 \\
960\end{array}$ & $\begin{array}{l}\text { Porcentaje } \\
62,8 \\
34,4 \\
97,2 \\
2,8 \\
100\end{array}$ & $\begin{array}{l}\text { Porcentaje } \\
\text { válido } \\
64,6 \\
35,4 \\
100\end{array}$ \\
\hline NORUEGA & $\begin{array}{l}\text { Permisiva } \\
\text { Restrictiva } \\
\text { Válido } \\
\text { Perdidos } \\
\mathrm{N} \text { total }\end{array}$ & $\begin{array}{l}\text { Frecuencia } \\
1081 \\
529 \\
1610 \\
14 \\
1624\end{array}$ & $\begin{array}{l}\text { Porcentaje } \\
66,6 \\
32,6 \\
99,1 \\
0,9 \\
100\end{array}$ & $\begin{array}{l}\text { Porcentaje } \\
\text { válido } \\
67,1 \\
32,9 \\
100\end{array}$ \\
\hline PAÍSES BAJOS & $\begin{array}{l}\text { Permisiva } \\
\text { Restrictiva } \\
\text { Válido } \\
\text { Perdidos } \\
\mathrm{N} \text { total }\end{array}$ & $\begin{array}{l}\text { Frecuencia } \\
990 \\
826 \\
1816 \\
29 \\
1845\end{array}$ & $\begin{array}{l}\text { Porcentaje } \\
53,7 \\
44,8 \\
98,4 \\
1,6 \\
100\end{array}$ & $\begin{array}{l}\text { Porcentaje } \\
\text { válido } \\
54,5 \\
45,5 \\
100\end{array}$ \\
\hline PORTUGAL & $\begin{array}{l}\text { Permisiva } \\
\text { Restrictiva } \\
\text { Válido } \\
\text { Perdidos } \\
\mathrm{N} \text { total }\end{array}$ & $\begin{array}{l}\text { Frecuencia } \\
650 \\
1420 \\
2070 \\
81 \\
2151\end{array}$ & $\begin{array}{l}\text { Porcentaje } \\
30,2 \\
66 \\
96,2 \\
3,8 \\
100\end{array}$ & $\begin{array}{l}\text { Porcentaje } \\
\text { válido } \\
31,4 \\
68,6 \\
100\end{array}$ \\
\hline REINO UNIDO & $\begin{array}{l}\text { Permisiva } \\
\text { Restrictiva } \\
\text { Válido } \\
\text { Perdidos } \\
\text { N total }\end{array}$ & $\begin{array}{l}\text { Frecuencia } \\
900 \\
1327 \\
2227 \\
59 \\
2286\end{array}$ & $\begin{array}{l}\text { Porcentaje } \\
39,4 \\
58 \\
97,4 \\
2,6 \\
100\end{array}$ & $\begin{array}{l}\text { Porcentaje } \\
\text { válido } \\
40,4 \\
59,6 \\
100\end{array}$ \\
\hline SUECIA & $\begin{array}{l}\text { Permisiva } \\
\text { Restrictiva } \\
\text { Válido } \\
\text { Perdidos } \\
\mathrm{N} \text { total }\end{array}$ & $\begin{array}{l}\text { Frecuencia } \\
1531 \\
291 \\
1822 \\
25 \\
1847\end{array}$ & $\begin{array}{l}\text { Porcentaje } \\
82,9 \\
15,8 \\
98,6 \\
1,4 \\
100\end{array}$ & $\begin{array}{l}\text { Porcentaje } \\
\text { válido } \\
84 \\
16 \\
100\end{array}$ \\
\hline
\end{tabular}




\begin{tabular}{|l|l|l|l|l|}
\hline SUIZA & & Frecuencia & Porcentaje & $\begin{array}{l}\text { Porcentaje } \\
\text { válido }\end{array}$ \\
& Permisiva & 862 & 57,7 & 59,1 \\
& Restrictiva & 596 & 39,9 & 40,9 \\
& Válido & 1458 & 97,7 & 100 \\
& Perdidos & 35 & 2,3 & \\
& N total & 1493 & 100 & \\
\hline
\end{tabular}

Fuente: elaboración propia a partir de la ESE 2012

ANEXO 5. VALORACIÓN MEDIA DEL EFECTO DE LA INMIGRACIÓN EN EL PAÍS RECEPTOR

\begin{tabular}{|lllll|}
\hline \multicolumn{4}{|c|}{ Valoración del efecto de la inmigración en la economía } \\
\hline & Media & Desv. Estándar & $\begin{array}{l}\mathrm{N} \\
\text { válidos }\end{array}$ & Perdidos \\
\hline Alemania & 5,71 & 2,288 & 2914 & 44 \\
Bélgica & 4,57 & 2,206 & 1859 & 10 \\
Dinamarca & 5,11 & 2,319 & 1600 & 50 \\
España & 5,23 & 2,55 & 1838 & 51 \\
Finlandia & 5,46 & 2,083 & 2177 & 20 \\
Francia & 4,68 & 2,488 & 1953 & 15 \\
Irlanda & 4,83 & 2,675 & 2589 & 39 \\
Islandia & 5,9 & 2,084 & 705 & 47 \\
Italia & 5,18 & 2,809 & 936 & 24 \\
Noruega & 5,94 & 2,059 & 1607 & 17 \\
Países & 5,25 & 2,039 & 1806 & 39 \\
Bajos & & 2,417 & 2007 & 144 \\
Portugal & 4,37 & 2,446 & 2233 & 53 \\
Reino & 4,43 & 2,272 & 1795 & 52 \\
Unido & 5,6 & 2,043 & 1476 & 17 \\
Suecia & 5,1 & &
\end{tabular}

Fuente: elaboración propia a partir de la ESE 2012 


\begin{tabular}{|lcccc|}
\hline \multicolumn{5}{|c|}{ Valoración del efecto de la inmigración en la cultura } \\
\hline & Media & Desv. Estándar & $\begin{array}{l}\mathrm{N} \\
\text { válidos }\end{array}$ & Perdidos \\
\hline Alemania & 6,2 & 2,366 & 291840 & 40 \\
Bélgica & 5,77 & 2,243 & 1856 & 13 \\
Dinamarca & 6,26 & 2,438 & 1621 & 29 \\
España & 6,22 & 2,485 & 1836 & 53 \\
Finlandia & 7,14 & 1,803 & 2181 & 16 \\
Francia & 5,19 & 2,698 & 1960 & 8 \\
Irlanda & 5,47 & 2,641 & 2563 & 65 \\
Islandia & 6,77 & 2,026 & 733 & 19 \\
Italia & 5,61 & 2,793 & 943 & 17 \\
Noruega & 6,05 & 2,272 & 1614 & 10 \\
Países & 6,26 & 1,96 & 1814 & 31 \\
Bajos & & & & \\
Portugal & 5,04 & 2,345 & 2011 & 140 \\
Reino & 5,03 & 2,571 & 2206 & 80 \\
Unido & & & & \\
Suecia & 6,97 & 2,244 & 1819 & 28 \\
Suiza & 6,09 & 2,209 & 1461 & 32
\end{tabular}

\begin{tabular}{|lcccc|}
\hline \multicolumn{5}{|c|}{ Valoración del efecto de la inmigración en las } \\
condiciones de vida \\
\hline & Media & Desv. Estándar & $\begin{array}{l}\text { N } \\
\text { válidos }\end{array}$ & Perdidos \\
\hline Alemania & 5,35 & 2,18 & 2921 & 37 \\
Bélgica & 4,74 & 2,113 & 1859 & 10 \\
Dinamarca & 6,05 & 2,218 & 1622 & 28 \\
España & 5,34 & 2,411 & 1843 & 46 \\
Finlandia & 5,61 & 1,911 & 2173 & 24 \\
Francia & 4,54 & 2,284 & 1943 & 25 \\
Irlanda & 5,37 & 2,623 & 2582 & 46 \\
Islandia & 6,48 & 1,979 & 724 & 28 \\
Italia & 4,4 & 2,497 & 937 & 23 \\
Noruega & 5,69 & 1,985 & 1610 & 14 \\
Países & 5,4 & 1,818 & 1819 & 26 \\
Bajos & & & & \\
Portugal & 3,88 & 2,057 & 2036 & 115 \\
Reino & 4,61 & 2,464 & 2229 & 57 \\
Unido & & & & \\
Suecia & 6,37 & 2,165 & 1817 & 30 \\
Suiza & 5,38 & 1,875 & 1451 & 42
\end{tabular}

Fuente: elaboración propia a partir de la ESE 2012 


\begin{tabular}{|c|c|c|c|}
\hline & $\begin{array}{l}\text { Valor Chi- } \\
\text { cuadrado }\end{array}$ & Sig. asintótica & $\begin{array}{c}\% \text { de casos que } \\
\text { han esperado un } \\
\text { recuento menor } \\
\text { que } 5\end{array}$ \\
\hline Alemania & 73,999 & 0 & 6,3 \\
\hline Bélgica & 66,214 & 0 & 9,1 \\
\hline Dinamarca & 169,528 & 0 & 0 \\
\hline España & 43,764 & 0 & 0 \\
\hline Finlandia & 135,293 & 0 & 0 \\
\hline Francia & 121,037 & 0 & 0 \\
\hline Irlanda & 20,494 & 0,001 & 0 \\
\hline Islandia & 13,075 & 0,042 & 21,4 \\
\hline Italia & 42,275 & 0 & 27,8 \\
\hline Noruega & 90,521 & 0 & 0 \\
\hline Países Bajos & 115,617 & 0 & 0 \\
\hline Portugal & 5,135 & 0,274 & 0 \\
\hline Reino Unido & 26,78 & 0 & 0 \\
\hline Suecia & 88,452 & 0 & 0 \\
\hline Suiza & 95,94 & 0 & 11,1 \\
\hline
\end{tabular}

\section{Alemania}

\begin{tabular}{|c|c|c|c|c|c|}
\hline & & & \multicolumn{2}{|c|}{ Actitud hacia la inmigración } & \multirow{2}{*}{ Total } \\
\hline & & & Permisiva & Restrictiva & \\
\hline \multirow{6}{*}{ Voto a partidos } & $\begin{array}{l}\text { Social Democratic Party of } \\
\text { Germany } \\
\text { (SPD) }\end{array}$ & Recuento & $\begin{array}{c}434 \\
72,8 \%\end{array}$ & $\begin{array}{c}162 \\
27,2 \%\end{array}$ & $\begin{array}{c}596 \\
100,0 \%\end{array}$ \\
\hline & $\begin{array}{l}\text { Christian Democratic } \\
\text { Union/Christian Social } \\
\text { Union (CDU/CSU) }\end{array}$ & $\begin{array}{l}\text { Recuento } \\
\%\end{array}$ & $\begin{array}{c}474 \\
64,0 \%\end{array}$ & $\begin{array}{r}267 \\
36,0 \%\end{array}$ & $\begin{array}{c}741 \\
100,0 \%\end{array}$ \\
\hline & $\begin{array}{l}\text { Alliance 90/The Greens } \\
\text { (GRÜNE) }\end{array}$ & Recuento & 174 & 25 & 199 \\
\hline & & $\%$ & $87,4 \%$ & $12,6 \%$ & $100,0 \%$ \\
\hline & $\begin{array}{l}\text { Free Democratic } \\
\text { Party (FDP) }\end{array}$ & Recuento & 43 & 27 & 70 \\
\hline & & $\%$ & $61,4 \%$ & $38,6 \%$ & $100,0 \%$ \\
\hline
\end{tabular}




\begin{tabular}{|c|c|c|c|c|c|}
\hline & The Left (Die Linke) & $\begin{array}{l}\text { Recuento } \\
\%\end{array}$ & $\begin{array}{c}91 \\
60,3 \%\end{array}$ & $\begin{array}{c}60 \\
39,7 \%\end{array}$ & $\begin{array}{c}151 \\
100,0 \%\end{array}$ \\
\hline & $\begin{array}{l}\text { National Democratic Party } \\
\text { of Germany (NPD) }\end{array}$ & $\begin{array}{l}\text { Recuento } \\
\%\end{array}$ & $\begin{array}{c}1 \\
8,3 \%\end{array}$ & $\begin{array}{c}11 \\
91,7 \%\end{array}$ & $\begin{array}{c}12 \\
100,0 \%\end{array}$ \\
\hline & $\begin{array}{l}\text { Pirate Party of Germany } \\
\text { (PIRATEN) }\end{array}$ & Recuento & 12 & 10 & 22 \\
\hline & & $\%$ & $54,5 \%$ & $45,5 \%$ & $100,0 \%$ \\
\hline & Otros partidos & Recuento & & & \\
\hline & & $\%$ & $70,8 \%$ & $29,2 \%$ & $100,0 \%$ \\
\hline & & Recuento & 1246 & 569 & 1815 \\
\hline & & $\%$ & $68,7 \%$ & $31,3 \%$ & $100,0 \%$ \\
\hline
\end{tabular}

Fuente: elaboración propia a partir de la ESE 2012

Bélgica

\begin{tabular}{|c|c|c|c|c|c|}
\hline & & & \multicolumn{2}{|c|}{ Actitud hacia la inmigración } & \multirow{2}{*}{ Total } \\
\hline & & & Permisiva & Restrictiva & \\
\hline \multirow{9}{*}{ Voto a partidos } & Green! & Recuento & 52 & 11 & 63 \\
\hline & & $\%$ & $82,5 \%$ & $17,5 \%$ & $100,0 \%$ \\
\hline & $\begin{array}{l}\text { Christian Democratic \& } \\
\text { Flemish (CD\&V) }\end{array}$ & Recuento & 112 & 82 & 194 \\
\hline & & $\%$ & $57,7 \%$ & $42,3 \%$ & $100,0 \%$ \\
\hline & New Flemish Alliance (N-VA) & Recuento & 93 & 101 & 194 \\
\hline & & $\%$ & $47,9 \%$ & $52,1 \%$ & $100,0 \%$ \\
\hline & $\begin{array}{l}\text { Socialist Party. Different } \\
\text { (SP.A) }\end{array}$ & Recuento & 95 & 48 & 143 \\
\hline & & $\%$ & $66,4 \%$ & $33,6 \%$ & $100,0 \%$ \\
\hline & Flemish Interest (Vlaams & Recuento & 15 & 32 & 47 \\
\hline
\end{tabular}




\begin{tabular}{|c|c|c|c|c|c|}
\hline & Belang) & $\%$ & $31,9 \%$ & $68,1 \%$ & $100,0 \%$ \\
\hline & $\begin{array}{l}\text { Flemish Liberals and } \\
\text { Democrats (Open VLD) }\end{array}$ & Recuento & 69 & 63 & \\
\hline & & $\%$ & $52,3 \%$ & $47,7 \%$ & $100,0 \%$ \\
\hline & $\begin{array}{l}\text { Humanist Democratic Center } \\
\text { (CDH) }\end{array}$ & Recuento & & 29 & \\
\hline & & $\%$ & $59,7 \%$ & $40,3 \%$ & $100,0 \%$ \\
\hline & Ecolo & Recuento & 50 & 19 & 69 \\
\hline & & $\%$ & $72,5 \%$ & $27,5 \%$ & $100,0 \%$ \\
\hline & Front Nacional (FN) & Recuento & 1 & 7 & 8 \\
\hline & & $\%$ & $12,5 \%$ & $87,5 \%$ & $100,0 \%$ \\
\hline & Reform Movement (MR) & Recuento & 52 & 70 & 122 \\
\hline & & $\%$ & $42,6 \%$ & $57,4 \%$ & $100,0 \%$ \\
\hline & Socialist Party (PS) & Recuento & 102 & 101 & 203 \\
\hline & & $\%$ & $50,2 \%$ & $49,8 \%$ & $100,0 \%$ \\
\hline & & Recuento & 684 & 563 & 1247 \\
\hline & & $\%$ & $54,9 \%$ & $45,1 \%$ & $100,0 \%$ \\
\hline
\end{tabular}

Fuente: elaboración propia a partir de la ESE 2012

\section{Dinamarca}

\begin{tabular}{|c|c|c|c|c|c|}
\hline & & & \multicolumn{2}{|c|}{ Actitud hacia la inmigración } & \multirow{2}{*}{ Total } \\
\hline & & & Permisiva & Restrictiva & \\
\hline \multirow{3}{*}{ Voto a partidos } & $\begin{array}{l}\text { The Danish Social } \\
\text { Democrats (S) }\end{array}$ & Recuento & 189 & 161 & 350 \\
\hline & & $\%$ & $54,0 \%$ & $46,0 \%$ & $100,0 \%$ \\
\hline & Danish social liberal party & Recuento & 101 & 55 & 156 \\
\hline
\end{tabular}




\begin{tabular}{|c|c|c|c|c|c|}
\hline & & $\%$ & $64,7 \%$ & $35,3 \%$ & $100,0 \%$ \\
\hline & Conservative (KF) & Recuento & 28 & 30 & 58 \\
\hline & & $\%$ & $48,3 \%$ & $51,7 \%$ & $100,0 \%$ \\
\hline & $\begin{array}{l}\text { Socialist people's party } \\
\text { (SF) }\end{array}$ & Recuento & & 42 & 139 \\
\hline & & $\%$ & $69,8 \%$ & $30,2 \%$ & $100,0 \%$ \\
\hline & Danish people party (DF) & Recuento & 19 & 95 & 114 \\
\hline & & $\%$ & $16,7 \%$ & $83,3 \%$ & $100,0 \%$ \\
\hline & Christian democrats & Recuento & 7 & 6 & 13 \\
\hline & & $\%$ & $53,8 \%$ & $46,2 \%$ & $100,0 \%$ \\
\hline & Venstre (V) & Recuento & 105 & 234 & 339 \\
\hline & & $\%$ & $31,0 \%$ & $69,0 \%$ & $100,0 \%$ \\
\hline & Liberal alliance (LA) & Recuento & 13 & 24 & 37 \\
\hline & & $\%$ & $35,1 \%$ & $64,9 \%$ & $100,0 \%$ \\
\hline & The red-green alliance & Recuento & 67 & 17 & 84 \\
\hline & & $\%$ & $79,8 \%$ & $20,2 \%$ & $100,0 \%$ \\
\hline & & Recuento & 626 & 664 & 1290 \\
\hline & & $\%$ & $48,5 \%$ & $51,5 \%$ & $100,0 \%$ \\
\hline
\end{tabular}

Fuente: elaboración propia a partir de la ESE 2012

\section{España}

\begin{tabular}{|c|c|c|c|c|c|}
\hline & & & \multicolumn{2}{|c|}{ Actitud hacia la inmigración } & \multirow{2}{*}{ Total } \\
\hline & & & Permisiva & Restrictiva & \\
\hline Voto a partidos & Partido Popular (PP) & Recuento & 220 & 254 & 474 \\
\hline
\end{tabular}




\begin{tabular}{|c|c|c|c|c|c|}
\hline & & $\%$ & $46,4 \%$ & $53,6 \%$ & $100,0 \%$ \\
\hline & $\begin{array}{l}\text { Partido Socialista Obrero } \\
\text { Español (PSOE) }\end{array}$ & Recuento & 181 & 138 & 319 \\
\hline & & $\%$ & $56,7 \%$ & $43,3 \%$ & $100,0 \%$ \\
\hline & & Recuento & 30 & 19 & 49 \\
\hline & & $\%$ & $61,2 \%$ & $38,8 \%$ & $100,0 \%$ \\
\hline & 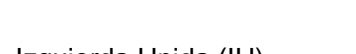 & Recuento & 68 & 17 & 85 \\
\hline & & $\%$ & $80,0 \%$ & $20,0 \%$ & $100,0 \%$ \\
\hline & $\begin{array}{l}\text { Unión Progreso y } \\
\text { Democracia (UPYD) }\end{array}$ & Recuento & 30 & 15 & 45 \\
\hline & & $\%$ & $66,7 \%$ & $33,3 \%$ & $100,0 \%$ \\
\hline & $\begin{array}{l}\text { Partido Nacionalista } \\
\text { Vasco (PNV) }\end{array}$ & Recuento & 9 & 12 & 21 \\
\hline & & $\%$ & $42,9 \%$ & $57,1 \%$ & $100,0 \%$ \\
\hline & $\begin{array}{l}\text { Esquerra Republicana } \\
\text { Catalana (ERC) }\end{array}$ & Recuento & & 7 & 18 \\
\hline & & $\%$ & $61,1 \%$ & $38,9 \%$ & $100,0 \%$ \\
\hline & & Recuento & 11 & 3 & 14 \\
\hline & & $\%$ & $78,6 \%$ & $21,4 \%$ & $100,0 \%$ \\
\hline & & Recuento & 560 & 465 & 1025 \\
\hline & & $\%$ & $54,6 \%$ & $45,4 \%$ & $100,0 \%$ \\
\hline
\end{tabular}

Fuente: elaboración propia a partir de la ESE 2012

Finlandia

\begin{tabular}{|ll|c|c|c|}
\hline \multicolumn{2}{|c|}{} & \multicolumn{2}{|c|}{ Actitud hacia la inmigración } & \multirow{2}{*}{ Total } \\
\cline { 3 - 4 } & & Permisiva & Restrictiva & \\
\hline $\begin{array}{l}\text { The national coallition } \\
\text { party (KOK) }\end{array}$ & Recuento & 127 & 241 & 368 \\
& $\%$ & $34,5 \%$ & $65,5 \%$ & $100,0 \%$ \\
\hline
\end{tabular}




\begin{tabular}{|c|c|c|c|c|c|}
\hline \multirow{13}{*}{ Voto a partidos } & $\begin{array}{l}\text { The swedish people's } \\
\text { party (SFP) }\end{array}$ & $\begin{array}{l}\text { Recuento } \\
\%\end{array}$ & $\begin{array}{c}53 \\
67,9 \%\end{array}$ & $\begin{array}{c}25 \\
32,1 \%\end{array}$ & $\begin{array}{c}78 \\
100,0 \%\end{array}$ \\
\hline & The centre party (KESK) & Recuento & 60 & 164 & 224 \\
\hline & & $\%$ & $26,8 \%$ & $73,2 \%$ & $100,0 \%$ \\
\hline & True Finns (PS) & Recuento & 40 & 161 & 201 \\
\hline & & $\%$ & $19,9 \%$ & $80,1 \%$ & $100,0 \%$ \\
\hline & Christian democrats (KD) & Recuento & 17 & 18 & 35 \\
\hline & & $\%$ & $48,6 \%$ & $51,4 \%$ & $100,0 \%$ \\
\hline & Green League (VHR) & Recuento & 110 & 55 & 165 \\
\hline & & $\%$ & $66,7 \%$ & $33,3 \%$ & $100,0 \%$ \\
\hline & $\begin{array}{l}\text { Social democratic party } \\
\text { (SDP) }\end{array}$ & Recuento & 98 & 183 & 281 \\
\hline & & $\%$ & $34,9 \%$ & $65,1 \%$ & $100,0 \%$ \\
\hline & Left alliance (VAS) & Recuento & 47 & 53 & 100 \\
\hline & & $\%$ & $47,0 \%$ & $53,0 \%$ & $100,0 \%$ \\
\hline \multirow{2}{*}{ Total } & & Recuento & 552 & 900 & 1452 \\
\hline & & $\%$ & $38,0 \%$ & $62,0 \%$ & $100,0 \%$ \\
\hline
\end{tabular}

Fuente: elaboración propia a partir de la ESE 2012

Francia

\begin{tabular}{|c|c|c|c|c|c|}
\hline & & & \multicolumn{2}{|c|}{ Actitud hacia la inmigración } & \multirow{2}{*}{ Total } \\
\hline & & & Permisiva & Restrictiva & \\
\hline \multirow{3}{*}{ voto a partidos } & Nouveau Centre (NC) & Recuento & 5 & 9 & 14 \\
\hline & & $\%$ & $35,7 \%$ & $64,3 \%$ & $100,0 \%$ \\
\hline & Front Nacional (FN) & Recuento & 30 & 96 & 126 \\
\hline
\end{tabular}




\begin{tabular}{|c|c|c|c|c|c|}
\hline & & $\%$ & $23,8 \%$ & $76,2 \%$ & $100,0 \%$ \\
\hline & $\begin{array}{l}\text { NPA (Nouveau Parti Anti- } \\
\text { Capitaliste) }\end{array}$ & Recuento & 12 & 3 & 15 \\
\hline & & $\%$ & $80,0 \%$ & $20,0 \%$ & $100,0 \%$ \\
\hline & LO (Lutte Ouvrière) & Recuento & 3 & 10 & 13 \\
\hline & & $\%$ & $23,1 \%$ & $76,9 \%$ & $100,0 \%$ \\
\hline & FDG (Front de Gauche) & Recuento & 45 & 16 & 61 \\
\hline & & $\%$ & $73,8 \%$ & $26,2 \%$ & $100,0 \%$ \\
\hline & $\begin{array}{l}\text { PRG (Parti Radical de } \\
\text { Gauche) }\end{array}$ & Recuento & 9 & 11 & \\
\hline & & $\%$ & $45,0 \%$ & $55,0 \%$ & $100,0 \%$ \\
\hline & $\begin{array}{l}\text { MPF (Mouvement pour la } \\
\text { France) }\end{array}$ & Recuento & 7 & 10 & 17 \\
\hline & & $\%$ & $41,2 \%$ & $58,8 \%$ & $100,0 \%$ \\
\hline & PS (Parti Socialiste) & Recuento & 286 & 168 & 454 \\
\hline & & $\%$ & $63,0 \%$ & $37,0 \%$ & $100,0 \%$ \\
\hline & $\begin{array}{l}\text { UMP (Union pour un } \\
\text { Mouvement Populaire) }\end{array}$ & Recuento & 146 & 209 & 355 \\
\hline & & $\%$ & $41,1 \%$ & $58,9 \%$ & $100,0 \%$ \\
\hline & $\begin{array}{l}\text { MODEM (Mouvement } \\
\text { Démocrate) }\end{array}$ & Recuento & 27 & 15 & 42 \\
\hline & & $\%$ & $64,3 \%$ & $35,7 \%$ & $100,0 \%$ \\
\hline & $\begin{array}{l}\text { EELV (Europe Ecologie Les } \\
\text { Verts) }\end{array}$ & Recuento & 42 & 11 & 53 \\
\hline & & $\%$ & $79,2 \%$ & $20,8 \%$ & $100,0 \%$ \\
\hline & $\begin{array}{l}\text { Autres mouvements } \\
\text { écologistes }\end{array}$ & Recuento & 8 & 5 & 13 \\
\hline & & $\%$ & $61,5 \%$ & $38,5 \%$ & $100,0 \%$ \\
\hline & & Recuento & 620 & 563 & 1183 \\
\hline & & $\%$ & $52,4 \%$ & $47,6 \%$ & $100,0 \%$ \\
\hline
\end{tabular}

Fuente: elaboración propia a partir de la ESE 2012 
Irlanda

\begin{tabular}{|c|c|c|c|c|c|}
\hline & & & Actitud haci & nmigración & \\
\hline & & & Permisiva & Restrictiva & \\
\hline & Fianna Fáil (FF) & Recuento & 130 & 177 & 307 \\
\hline & & $\%$ & $42,3 \%$ & $57,7 \%$ & $100,0 \%$ \\
\hline & Fine Gael (FG) & Recuento & 315 & 370 & 685 \\
\hline & & $\%$ & $46,0 \%$ & $54,0 \%$ & $100,0 \%$ \\
\hline & Green Party (GP) & Recuento & 22 & 15 & 37 \\
\hline & & $\%$ & $59,5 \%$ & $40,5 \%$ & $100,0 \%$ \\
\hline & Independent & Recuento & 99 & 74 & 173 \\
\hline & & $\%$ & $57,2 \%$ & $42,8 \%$ & $100,0 \%$ \\
\hline & Labour (Lab) & Recuento & 137 & 104 & 241 \\
\hline & & $\%$ & $56,8 \%$ & $43,2 \%$ & $100,0 \%$ \\
\hline & Sinn Féin (SF) & Recuento & 89 & 85 & 174 \\
\hline & & $\%$ & $51,1 \%$ & $48,9 \%$ & $100,0 \%$ \\
\hline & & Recuento & 792 & 825 & 1617 \\
\hline & & $\%$ & $49,0 \%$ & $51,0 \%$ & $100,0 \%$ \\
\hline
\end{tabular}

Fuente: elaboración propia a partir de la ESE 2012

Islandia

\begin{tabular}{|c|c|c|c|}
\hline \multirow{2}{*}{} & \multicolumn{2}{|c|}{ Actitud hacia la inmigración } & \multirow{2}{*}{ Total } \\
\cline { 3 - 4 } & Permisiva & Restrictiva & \\
\hline Alianza Socialdemócrata Recuento & 110 & 30 & \multirow{2}{*}{140} \\
\hline
\end{tabular}




\begin{tabular}{|c|c|c|c|c|c|}
\hline \multirow{13}{*}{ Voto a partidos } & (AS) & $\%$ & $78,6 \%$ & $21,4 \%$ & $100,0 \%$ \\
\hline & Partido Progresista (PP) & Recuento & 49 & 21 & 70 \\
\hline & & $\%$ & $70,0 \%$ & $30,0 \%$ & $100,0 \%$ \\
\hline & $\begin{array}{l}\text { Partido de la } \\
\text { Independencia (PI) }\end{array}$ & Recuento & 92 & 56 & 148 \\
\hline & & $\%$ & $62,2 \%$ & $37,8 \%$ & $100,0 \%$ \\
\hline & $\begin{array}{l}\text { Movimiento de Izquierda- } \\
\text { Verde (IV) }\end{array}$ & Recuento & 82 & 22 & 104 \\
\hline & & $\%$ & $78,8 \%$ & $21,2 \%$ & $100,0 \%$ \\
\hline & Partido Liberal (PL) & Recuento & & 1 & \\
\hline & & $\%$ & $75,0 \%$ & $25,0 \%$ & $100,0 \%$ \\
\hline & Movimiento ciudadano & Recuento & & & 19 \\
\hline & & $\%$ & $73,7 \%$ & $26,3 \%$ & $100,0 \%$ \\
\hline & & Recuento & 14 & 4 & 18 \\
\hline & & $\%$ & $77,8 \%$ & $22,2 \%$ & $100,0 \%$ \\
\hline \multirow{2}{*}{ Total } & & Recuento & 364 & 139 & 503 \\
\hline & & $\%$ & $72,4 \%$ & $27,6 \%$ & $100,0 \%$ \\
\hline
\end{tabular}

Fuente: elaboración propia a partir de la ESE 2012

\section{Italia}

\begin{tabular}{|c|c|c|c|c|c|}
\hline & & & \multicolumn{2}{|c|}{ Actitud hacia la inmigración } & \multirow{2}{*}{ Total } \\
\hline & & & Permisiva & Restrictiva & \\
\hline \multirow{4}{*}{ Voto a partidos } & Partido democrático (PD) & Recuento & 155 & 44 & 199 \\
\hline & & $\%$ & $77,9 \%$ & $22,1 \%$ & $100,0 \%$ \\
\hline & $\begin{array}{l}\text { Izquierda, Ecología y } \\
\text { Libertad (SEL) }\end{array}$ & Recuento & 28 & 4 & 32 \\
\hline & & $\%$ & $87,5 \%$ & $12,5 \%$ & $100,0 \%$ \\
\hline
\end{tabular}




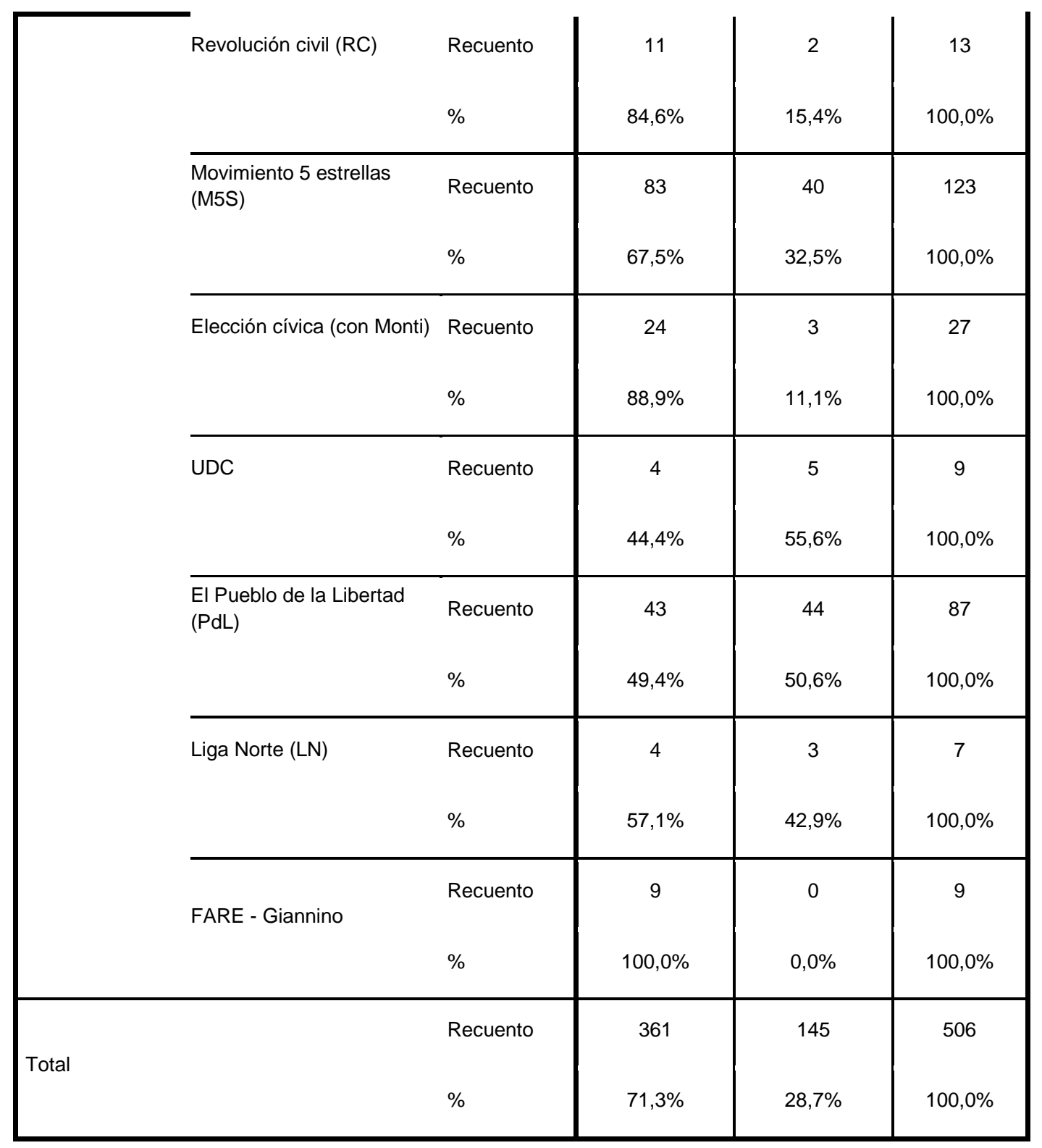

Fuente: elaboración propia a partir de la ESE 2012

Noruega

\begin{tabular}{|c|c|c|c|c|c|}
\hline & & & \multicolumn{2}{|c|}{ Actitud hacia la inmigración } & \multirow{2}{*}{ Total } \\
\hline & & & Permisiva & Restrictiva & \\
\hline \multirow{3}{*}{ Voto a partidos } & Socialist left party (SV) & Recuento & 63 & 6 & 69 \\
\hline & & $\%$ & $91,3 \%$ & $8,7 \%$ & $100,0 \%$ \\
\hline & Labour party (A/ap) & Recuento & 311 & 123 & 434 \\
\hline
\end{tabular}




\begin{tabular}{|c|c|c|c|c|c|}
\hline & & $\%$ & $71,7 \%$ & $28,3 \%$ & $100,0 \%$ \\
\hline & Liberal party (V) & Recuento & 47 & 11 & 58 \\
\hline & & $\%$ & $81,0 \%$ & $19,0 \%$ & $100,0 \%$ \\
\hline & $\begin{array}{l}\text { Christian democratic party } \\
(\mathrm{KrF})\end{array}$ & Recuento & & & 70 \\
\hline & & $\%$ & $90,0 \%$ & $10,0 \%$ & $100,0 \%$ \\
\hline & Centre party (Sp) & Recuento & 50 & 29 & 79 \\
\hline & & $\%$ & $63,3 \%$ & $36,7 \%$ & $100,0 \%$ \\
\hline & Conservative party $(\mathrm{H})$ & Recuento & 177 & 127 & 304 \\
\hline & & $\%$ & $58,2 \%$ & $41,8 \%$ & $100,0 \%$ \\
\hline & Progress party (FrP) & Recuento & 56 & 75 & 131 \\
\hline & & $\%$ & $42,7 \%$ & $57,3 \%$ & $100,0 \%$ \\
\hline & & Recuento & 767 & 378 & 1145 \\
\hline & & $\%$ & $67,0 \%$ & $33,0 \%$ & $100,0 \%$ \\
\hline
\end{tabular}

Fuente: elaboración propia a partir de la ESE 2012

Países Bajos

\begin{tabular}{|c|c|c|c|c|c|}
\hline & & & \multicolumn{2}{|c|}{ Actitud hacia la inmigración } & \multirow{2}{*}{ Total } \\
\hline & & & Permisiva & Restrictiva & \\
\hline \multirow{5}{*}{ Voto a partidos } & $\begin{array}{l}\text { Party for freedom and } \\
\text { democracy } \\
\text { (VVD) }\end{array}$ & $\begin{array}{l}\text { Recuento } \\
\%\end{array}$ & $\begin{array}{c}172 \\
48,3 \%\end{array}$ & $\begin{array}{c}184 \\
51,7 \%\end{array}$ & $\begin{array}{c}356 \\
100,0 \%\end{array}$ \\
\hline & Labour party (PvdA) & Recuento & 231 & 112 & 343 \\
\hline & & $\%$ & $67,3 \%$ & $32,7 \%$ & $100,0 \%$ \\
\hline & PVV (List Wilders) & Recuento & 15 & 81 & 96 \\
\hline & & $\%$ & $15,6 \%$ & $84,4 \%$ & $100,0 \%$ \\
\hline
\end{tabular}




\begin{tabular}{|c|c|c|c|c|c|}
\hline & $\begin{array}{l}\text { Christian Democratic } \\
\text { party (CDA) }\end{array}$ & $\begin{array}{l}\text { Recuento } \\
\%\end{array}$ & $\begin{array}{c}69 \\
50,0 \%\end{array}$ & $\begin{array}{c}69 \\
50,0 \%\end{array}$ & $\begin{array}{c}138 \\
100,0 \%\end{array}$ \\
\hline & Socialistic party (SP) & Recuento & & 48 & 139 \\
\hline & & $\%$ & $65,5 \%$ & $34,5 \%$ & $100,0 \%$ \\
\hline & Democrats '66 (D66) & Recuento & 88 & 37 & 125 \\
\hline & & $\%$ & $70,4 \%$ & $29,6 \%$ & $100,0 \%$ \\
\hline & Green left & Recuento & 28 & 10 & 38 \\
\hline & & $\%$ & $73,7 \%$ & $26,3 \%$ & $100,0 \%$ \\
\hline & Christian Union (CU) & Recuento & 22 & 18 & 40 \\
\hline & & $\%$ & $55,0 \%$ & $45,0 \%$ & $100,0 \%$ \\
\hline & $\begin{array}{l}\text { Social Reformed party } \\
\text { (SGP) }\end{array}$ & Recuento & 18 & 16 & 34 \\
\hline & & $\%$ & $52,9 \%$ & $47,1 \%$ & $100,0 \%$ \\
\hline & Party for the animals & Recuento & 16 & 11 & 27 \\
\hline & & $\%$ & $59,3 \%$ & $40,7 \%$ & $100,0 \%$ \\
\hline & 50Plus & Recuento & 12 & 18 & 30 \\
\hline & & $\%$ & $40,0 \%$ & $60,0 \%$ & $100,0 \%$ \\
\hline & & Recuento & 762 & 604 & 1366 \\
\hline & & $\%$ & $55,8 \%$ & $44,2 \%$ & $100,0 \%$ \\
\hline
\end{tabular}

Fuente: elaboración propia a partir de la ESE 2012 
Portugal

\begin{tabular}{|c|c|c|c|c|c|}
\hline & & & \multicolumn{2}{|c|}{ Actitud hacia la inmigración } & \multirow{2}{*}{ Total } \\
\hline & & & Permisiva & Restrictiva & \\
\hline \multirow{10}{*}{ Voto a partidos } & Bloco de Esquerda (BE) & Recuento & 24 & 30 & 54 \\
\hline & & $\%$ & $44,4 \%$ & $55,6 \%$ & $100,0 \%$ \\
\hline & $\begin{array}{l}\text { Centro Democrático } \\
\text { Social - Partido Popular } \\
\text { (CDS-PP) }\end{array}$ & Recuento & 12 & 20 & 32 \\
\hline & & $\%$ & $37,5 \%$ & $62,5 \%$ & $100,0 \%$ \\
\hline & $\begin{array}{l}\text { ColigaÇao Democrática } \\
\text { Unitaria (CDU) }\end{array}$ & Recuento & 22 & 57 & 79 \\
\hline & & $\%$ & $27,8 \%$ & $72,2 \%$ & $100,0 \%$ \\
\hline & $\begin{array}{l}\text { Partido Social } \\
\text { Demócrata (PSD) }\end{array}$ & Recuento & 98 & 204 & 302 \\
\hline & & $\%$ & $32,5 \%$ & $67,5 \%$ & $100,0 \%$ \\
\hline & Partido Socialista (PS) & Recuento & 102 & 230 & 332 \\
\hline & & $\%$ & $30,7 \%$ & $69,3 \%$ & $100,0 \%$ \\
\hline \multirow{2}{*}{ Total } & & Recuento & 258 & 541 & 799 \\
\hline & & $\%$ & $32,3 \%$ & $67,7 \%$ & $100,0 \%$ \\
\hline
\end{tabular}

Fuente: elaboración propia a partir de la ESE 2012

Reino Unido

\begin{tabular}{|c|c|c|c|c|c|}
\hline & & & \multicolumn{2}{|c|}{ Actitud hacia la inmigración } & \multirow{2}{*}{ Total } \\
\hline & & & Permisiva & Restrictiva & \\
\hline \multirow{3}{*}{ voto a partidos } & Conservative (Cons) & Recuento & 151 & 337 & 488 \\
\hline & & $\%$ & $30,9 \%$ & $69,1 \%$ & $100,0 \%$ \\
\hline & Labour (Lab) & Recuento & 205 & 300 & 505 \\
\hline
\end{tabular}




\begin{tabular}{|c|c|c|c|c|c|}
\hline & & $\%$ & $40,6 \%$ & $59,4 \%$ & $100,0 \%$ \\
\hline & $\begin{array}{l}\text { Liberal Democrat party } \\
\text { (LDP) }\end{array}$ & Recuento & 124 & 127 & 251 \\
\hline & & $\%$ & $49,4 \%$ & $50,6 \%$ & $100,0 \%$ \\
\hline & $\begin{array}{l}\text { Scottish National Party } \\
\text { (SNP) }\end{array}$ & Recuento & 16 & & 37 \\
\hline & & $\%$ & $43,2 \%$ & $56,8 \%$ & $100,0 \%$ \\
\hline & Plaid Cymru (PL) & Recuento & 7 & 14 & 21 \\
\hline & & $\%$ & $33,3 \%$ & $66,7 \%$ & $100,0 \%$ \\
\hline & Green Party (GP) & Recuento & 9 & 9 & 18 \\
\hline & & $\%$ & $50,0 \%$ & $50,0 \%$ & $100,0 \%$ \\
\hline & & Recuento & 512 & 808 & 1320 \\
\hline & & $\%$ & $38,8 \%$ & $61,2 \%$ & $100,0 \%$ \\
\hline
\end{tabular}

Fuente: elaboración propia a partir de la ESE 2012

\section{Suecia}

\begin{tabular}{|c|c|c|c|c|c|}
\hline & & & Actitud ha & nmigración & \\
\hline & & & Permisiva & Restrictiva & \\
\hline & & Recuento & 64 & 8 & 72 \\
\hline & & $\%$ & $88,9 \%$ & $11,1 \%$ & $100,0 \%$ \\
\hline & $\begin{array}{l}\text { Popular liberal party } \\
\text { (FP) }\end{array}$ & Recuento & 106 & 9 & 115 \\
\hline Voto a partidos & & $\%$ & $92,2 \%$ & $7,8 \%$ & $100,0 \%$ \\
\hline & $\begin{array}{l}\text { Christian democratic } \\
\text { party (KD) }\end{array}$ & Recuento & 44 & 3 & 47 \\
\hline & & $\%$ & $93,6 \%$ & $6,4 \%$ & $100,0 \%$ \\
\hline & Green party (MP) & Recuento & 125 & 13 & 138 \\
\hline
\end{tabular}




\begin{tabular}{|c|c|c|c|c|c|}
\hline & & $\%$ & $90,6 \%$ & $9,4 \%$ & $100,0 \%$ \\
\hline & Moderate Party (M) & Recuento & & & \\
\hline & & $\%$ & $82,0 \%$ & $18,0 \%$ & $100,0 \%$ \\
\hline & $\begin{array}{l}\text { Social democratic party } \\
\text { (S) }\end{array}$ & Recuento & 386 & 64 & 450 \\
\hline & & $\%$ & $85,8 \%$ & $14,2 \%$ & $100,0 \%$ \\
\hline & Left party (V) & Recuento & 69 & 6 & 75 \\
\hline & & $\%$ & $92,0 \%$ & $8,0 \%$ & $100,0 \%$ \\
\hline & $\begin{array}{l}\text { Sweden democrats } \\
\text { (SD) }\end{array}$ & Recuento & 30 & 34 & 64 \\
\hline & & $\%$ & $46,9 \%$ & $53,1 \%$ & $100,0 \%$ \\
\hline & & Recuento & Recuento & 217 & 1406 \\
\hline & & $\%$ & $\%$ & $15,4 \%$ & $100,0 \%$ \\
\hline
\end{tabular}

Fuente: elaboración propia a partir de la ESE 2012

\section{Suiza}

\begin{tabular}{|c|c|c|c|c|c|}
\hline & & & Actitud hac & nmigración & \\
\hline & & & Permisiva & Restrictiva & \\
\hline & $\begin{array}{l}\text { Swiss People's Party } \\
\text { (SVP) }\end{array}$ & Recuento & 32 & 98 & 130 \\
\hline & & $\%$ & $24,6 \%$ & $75,4 \%$ & $100,0 \%$ \\
\hline & Socialist Party (SP) & Recuento & 92 & 27 & 119 \\
\hline & & $\%$ & $77,3 \%$ & $22,7 \%$ & $100,0 \%$ \\
\hline & Radical Liberals (PLR) & Recuento & 62 & 44 & 106 \\
\hline & & $\%$ & $58,5 \%$ & $41,5 \%$ & $100,0 \%$ \\
\hline & $\begin{array}{l}\text { Christian Democrats } \\
\text { (PDC) }\end{array}$ & Recuento & 67 & 57 & 124 \\
\hline & & $\%$ & $54,0 \%$ & $46,0 \%$ & $100,0 \%$ \\
\hline
\end{tabular}




\begin{tabular}{|c|c|c|c|c|c|}
\hline & Green Party (PES) & $\begin{array}{l}\text { Recuento } \\
\%\end{array}$ & $\begin{array}{c}55 \\
79,7 \%\end{array}$ & $\begin{array}{c}14 \\
20,3 \%\end{array}$ & $\begin{array}{c}69 \\
100,0 \%\end{array}$ \\
\hline & $\begin{array}{l}\text { Green Liberal Party } \\
\text { (GLP) }\end{array}$ & Recuento & & 23 & \\
\hline & & $\%$ & $68,1 \%$ & $31,9 \%$ & $100,0 \%$ \\
\hline & $\begin{array}{l}\text { Bourgois-democratic } \\
\text { Party (BDP) }\end{array}$ & Recuento & 23 & 17 & 40 \\
\hline & & $\%$ & $57,5 \%$ & $42,5 \%$ & $100,0 \%$ \\
\hline & $\begin{array}{l}\text { Evangelical People's } \\
\text { Party (EVP) }\end{array}$ & Recuento & 10 & & 14 \\
\hline & & $\%$ & $71,4 \%$ & $28,6 \%$ & $100,0 \%$ \\
\hline & $\begin{array}{l}\text { Federal Democratic } \\
\text { Union (UDF) }\end{array}$ & Recuento & 4 & 4 & 8 \\
\hline & & $\%$ & $50,0 \%$ & $50,0 \%$ & $100,0 \%$ \\
\hline & & Recuento & 394 & 288 & 682 \\
\hline & & $\%$ & $57,8 \%$ & $42,2 \%$ & $100,0 \%$ \\
\hline
\end{tabular}

